\title{
Employment and Micro and Small Enterprises
}

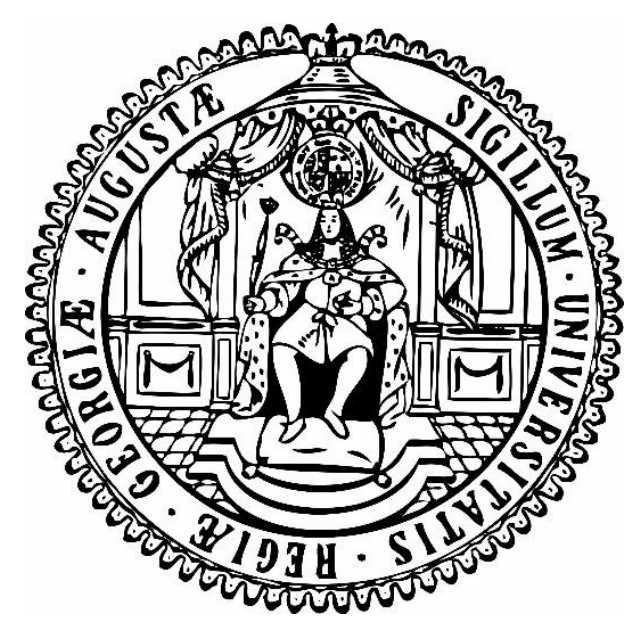

\section{DISSERTATION}

Submitted in accordance with the requirements for the doctoral degree in economic sciences at the Georg-August-Universität Göttingen

by

\section{Sarah Wiegel}

Born in Magdeburg, Germany

September 2019 


\section{Thesis Committee}

First supervisor: $\quad$ Apl. Prof. Dr. Jann Lay

Second supervisor: $\quad$ Prof. Dr. h.c. Stephan Klasen, Ph.D.

Third examiner: $\quad$ Prof. Dr. Renate Hartwig

Date of submission: $\quad 26.09 .2019$ 


\section{Acknowledgements}

This dissertation project brought me to places I would probably not have seen otherwise: from the colourful, cramped and chaotic markets of Kampala to the homes of small-scale entrepreneurs in Colombo. I am extremely grateful to my supervisor Jann Lay who opened up these opportunities for me and trusted me with exciting and challenging tasks. His enthusiasm for and interest in development topics inspired me. Without his guidance, advice and encouragement, I would not have finished this dissertation. I further thank my second supervisor Stephan Klasen for his valuable suggestions and Renate Hartwig for agreeing to participate in my thesis committee.

Parts of this thesis are based on own collected survey data. Thus, I extend my gratitude to (former) colleagues at GIGA as well as the interviewer teams in Uganda and Sri Lanka who invested much effort and energy in the data collection. My thanks also go to the numerous survey respondents who welcomed us to their businesses and homes and took the time to patiently answer our questions.

I am grateful to my parents who enabled me to pursue this path and instilled in me the interest to learn more about foreign countries and cultures. I thank my husband Johannes for his love and support. Finally, I thank my friends and colleagues at GIGA for their constant support, interest, company, patience and motivation throughout the past years. 



\section{CONTENTS}

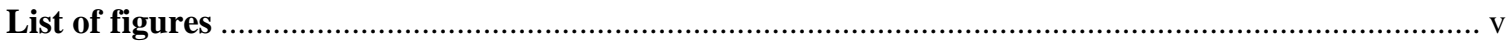

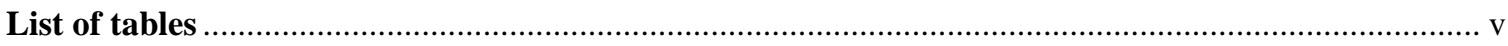

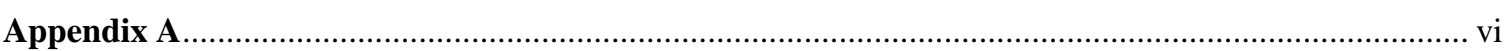

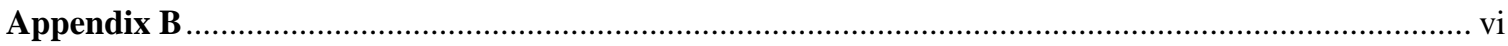

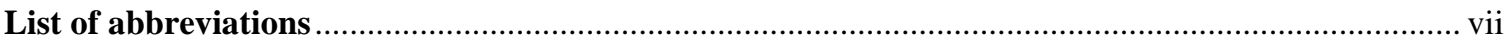

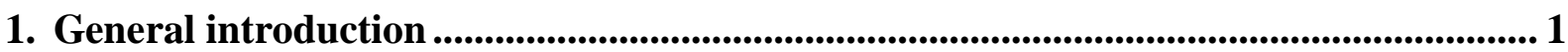

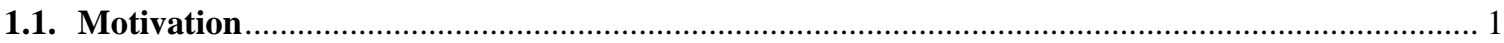

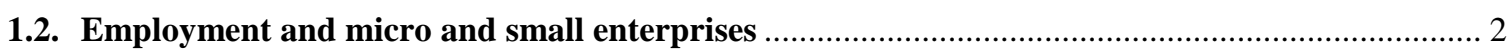

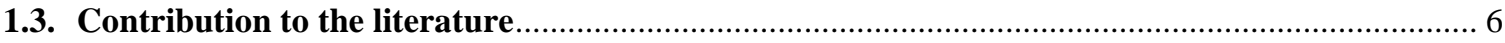

\section{SMARTer indicators for decent work in a post-2015 development agenda: A}

proposal ......................................................................................................................................................... 10

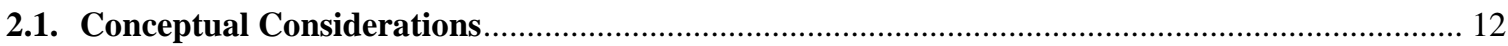

2.1.1. Foundations and challenges of employment-related development targets......................... 12

2.1.2. The relationship between employment and social protection ............................................. 13

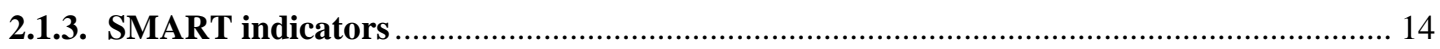

2.2. A critical review of the employment-related MDG indicators ................................................... 14

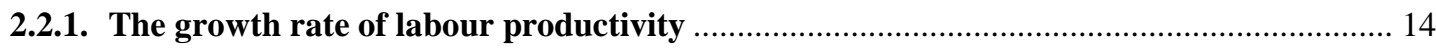

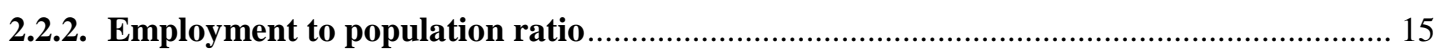

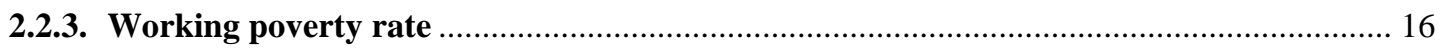

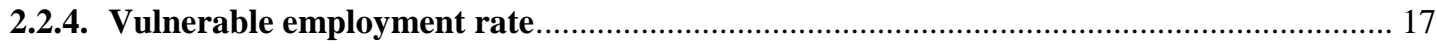

2.2.5. Share of women in wage employment in the non-agricultural sector ................................ 17

2.3. Proposal for a new employment target and set of indicators ....................................................... 18

2.3.1. Indicator 1: Growth of labour value added per worker …………………….................. 20

2.3.2. Indicator 2: Working poverty rate ……………............................................................ 20

2.3.3. Indicators 3a and 3b: Proportions of workers earning less than an absolute and a relative

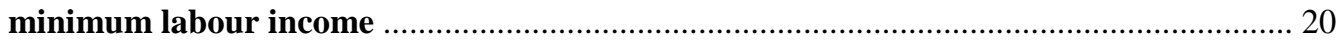

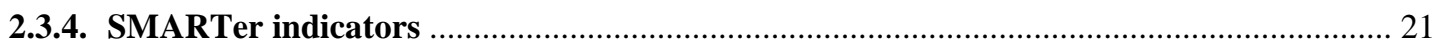

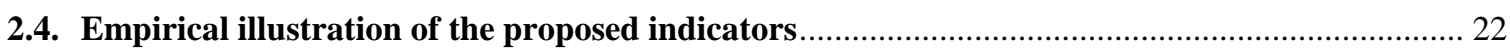

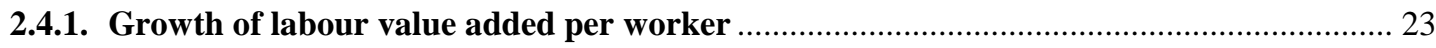

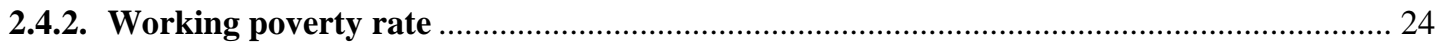

2.4.3. Workers earning less than absolute and relative minimum labour incomes ...................... 26

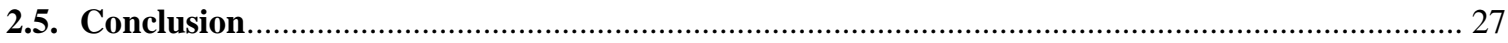


3. The puzzle of successful minority-run businesses in developing countries: A review 29

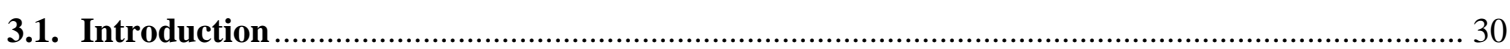

3.2. Patterns and performance of minority businesses in developing countries ................................ 33

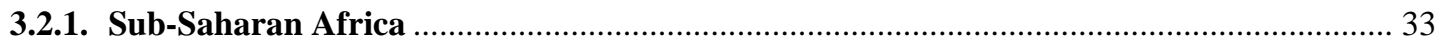

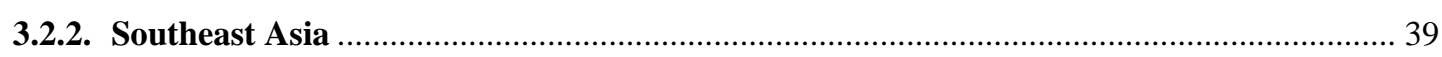

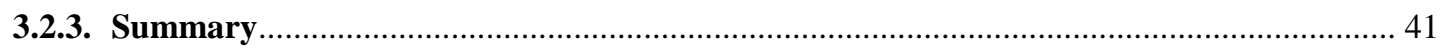

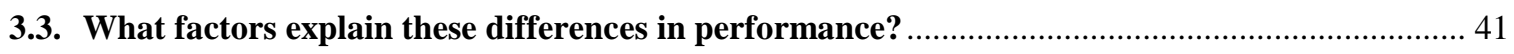

3.3.1. Culture, individual characteristics and selective migration ............................................. 42

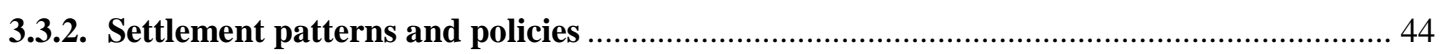

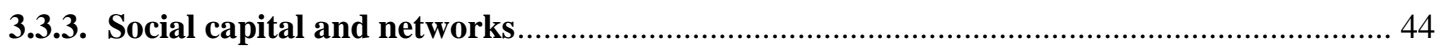

3.3.4. Overcoming institutional failure (contract enforcement) ..................................................... 47

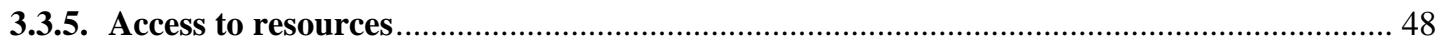

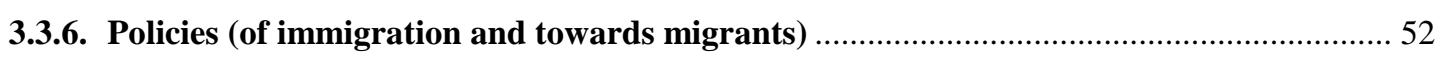

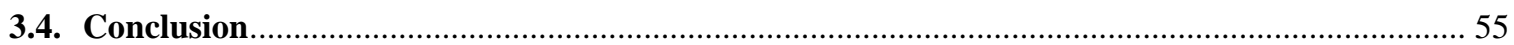

\section{The Role of Social Capital in Alleviating Credit Constraints: A Study of}

Entrepreneurs in Sri Lanka............................................................................................................... 58

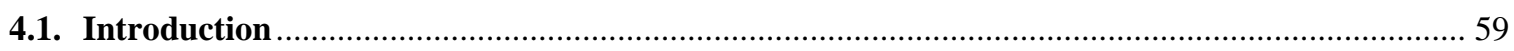

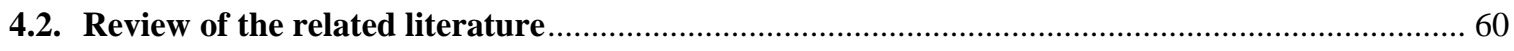

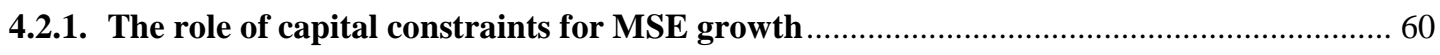

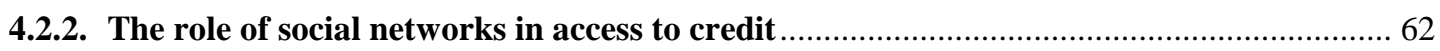

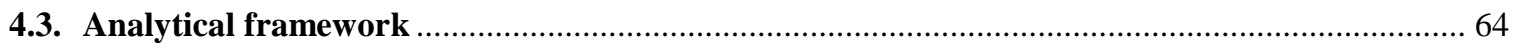

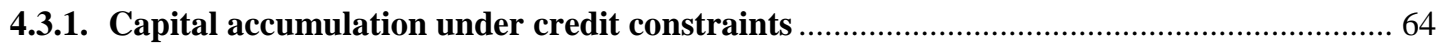

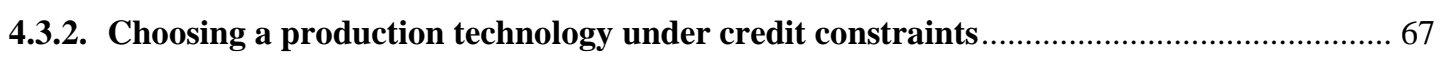

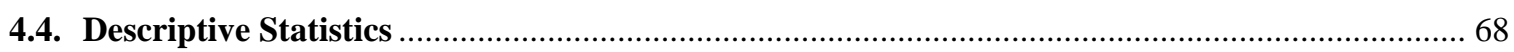

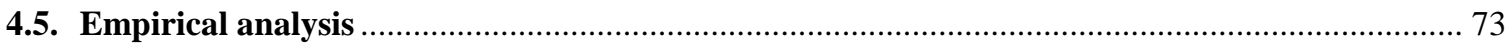

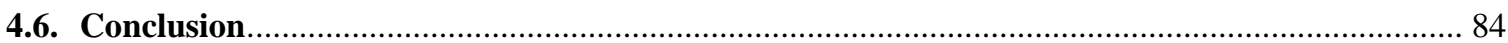

5. Firm performance and workers' wages Evidence from Microenterprises in Uganda 85

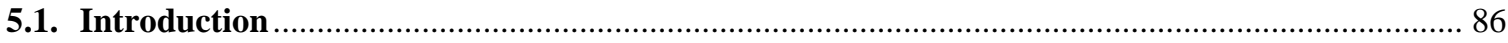

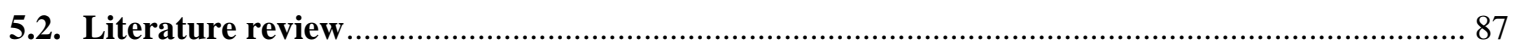

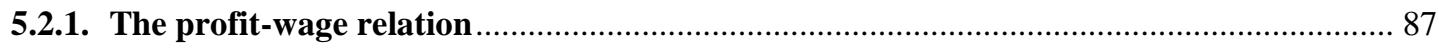

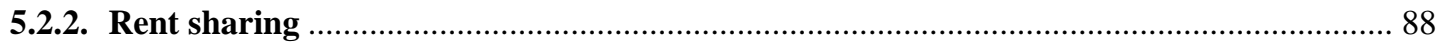

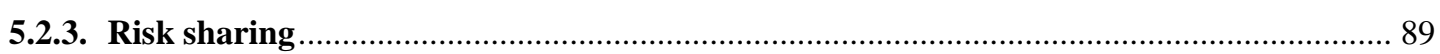

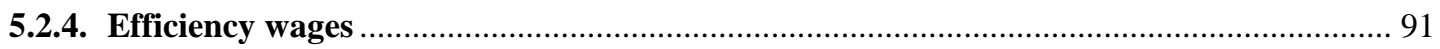

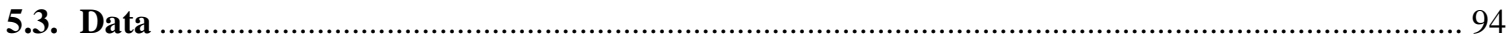

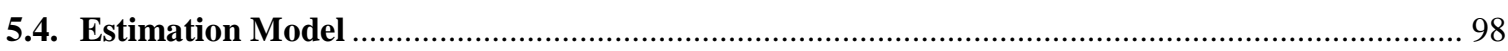

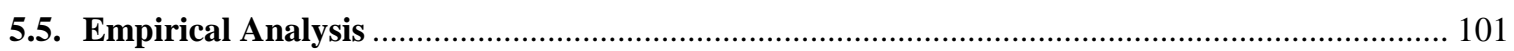

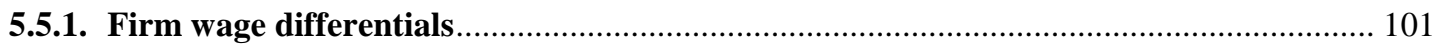

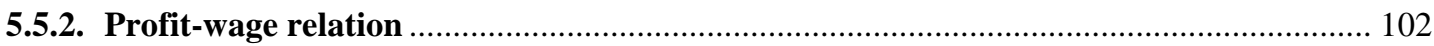




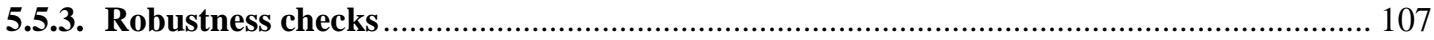

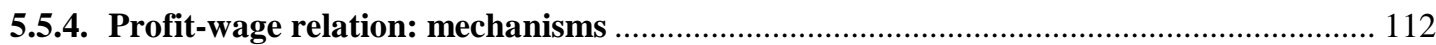

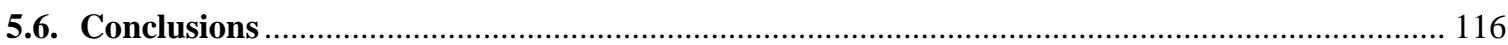

References ............................................................................................................................................... 118

Appendix A

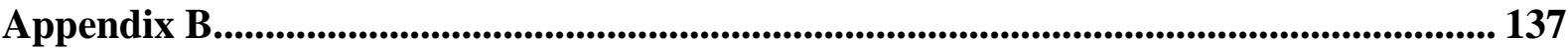

Declaration for admission to the doctoral examination.................................................... 139

Declaration about co-authored papers ......................................................................................... 140

\section{List of figures}

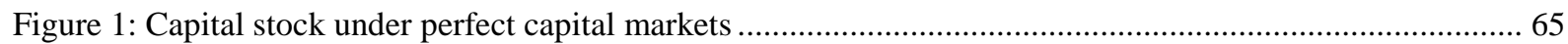

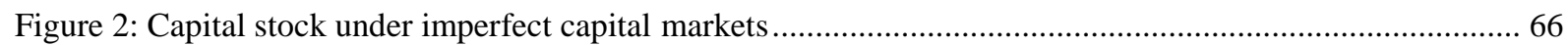

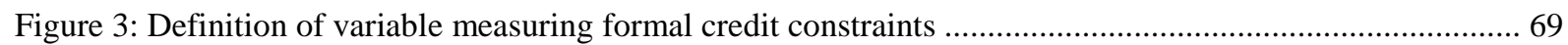

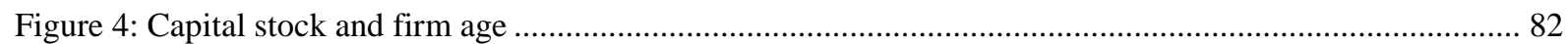

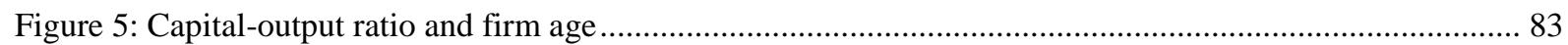

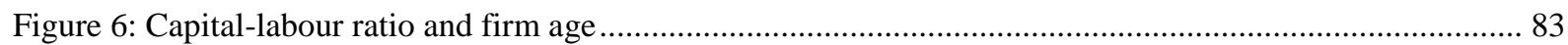

\section{List of tables}

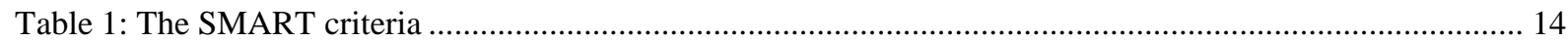

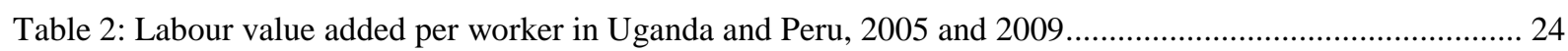

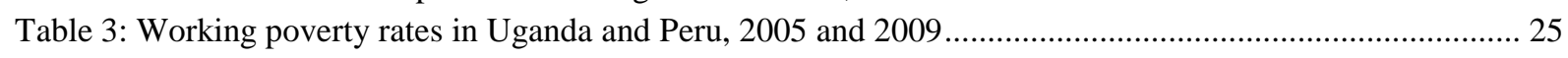

Table 4: Workers earning less than absolute/relative thresholds in Uganda and Peru, 2005 and 2009 .............. 27

Table 5: Representation of ethnic minorities in firm ownership and the population in selected countries .......... 34

Table 6: Characteristics of overseas Chinese in Southeast Asia ................................................................ 40

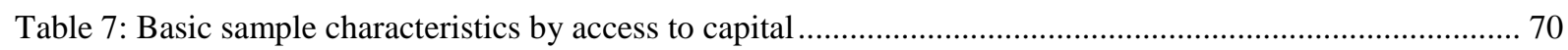

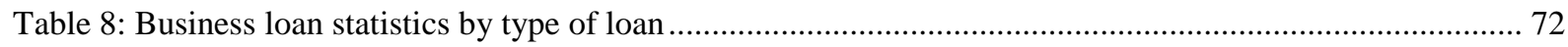

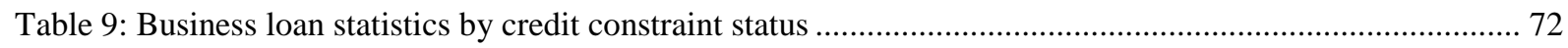

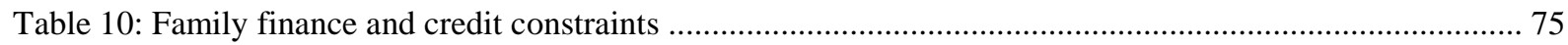

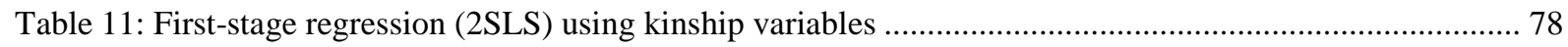

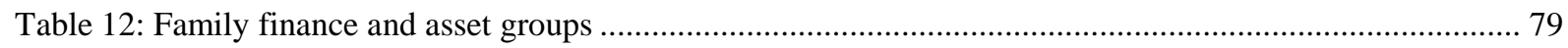

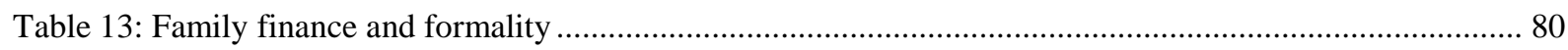

Table 14: Correlation matrix for measures of credit constraints ................................................................. 81

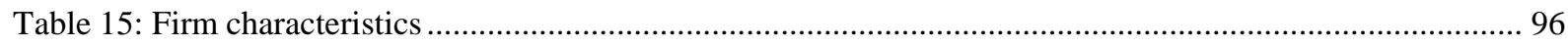

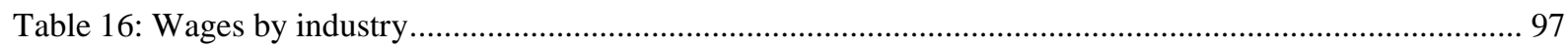

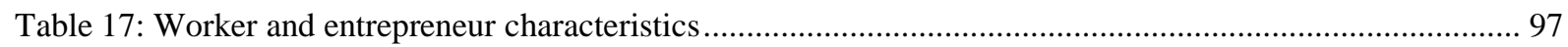

Table 18: Worker level vs. firm-level wage determinants .................................................................. 101

Table 19: Firm-level wage determinants (EDV approach using firm-time fixed effects from Table 18) .......... 104

Table 20: Firm-level wage determinants (EDV approach using firm-fixed effects from Table 18) ................. 106 
Table 21: Robustness check: Multilevel model ................................................................................... 108

Table 22: Robustness check, EDV approach, lagged profit ....................................................................... 110

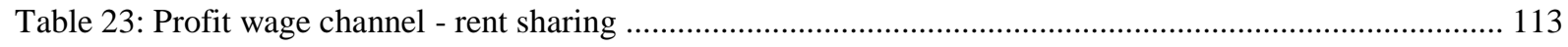

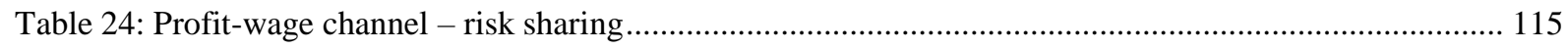

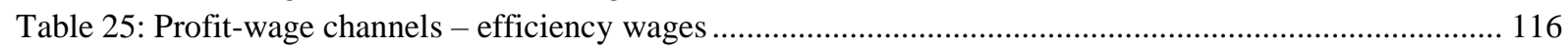

\section{Appendix A}

Table A. 1: Basic sample characteristics, by reason for being defined credit-unconstrained .......................... 134

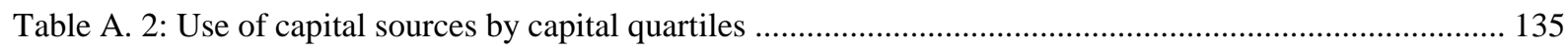

Table A. 3: Importance of capital sources by capital quartiles ............................................................. 135

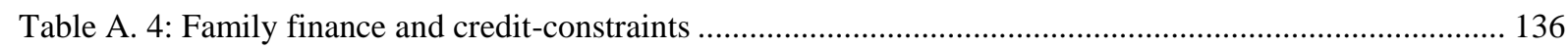

\section{Appendix B}

Table B. 1: EDV regression, FGLS

Table B. 2: Wage regression with 2012 data only....... 


\section{List of abbreviations}

2SLS Two-Stage Least Squares

$\mathrm{ADB}$

Asian Development Bank

BMZ Bundesministerium für wirschaftliche Zusammenarbeit (Federal Ministry for Economic Cooperation and Development)

CPI Consumer Price Index

EDV Estimated Dependent Variable

ENAHO Encuesta Nacional de Hogares (National Household Survey)

EPR Employment-to-Population Ratio

FE Fixed Effects

FGLS Feasible Generalized Least Squares

GDP Gross Domestic Product

GIGA German Institute of Global and Area Studies

GNI Gross National Income

ILO International Labour Organisation

KfW Kreditanstalt für Wiederaufbau (German Development Bank)

LCU Local Currency Unit

LFPR Labour Force Participation Rate

MDG Millennium Development Goals

MLE Maximum Likelihood Estimator

MPK Marginal Product of Capital

MSE Micro and Small Enterprises

OLS Ordinary Least Squares

PPP Purchasing Power Parity

ROSCA Rotating Savings and Credit Association

SD Standard Deviation

SSA sub-Saharan Africa

SDG Sustainable Development Goals

UGX Uganda Shilling

UNDP United Nations Development Programme

UNHS Uganda National Household Survey

WLS Weighted Least Squares

WPR Working Poverty Rate 



\section{CHAPTER 1}

\section{General introduction}

\subsection{Motivation}

The creation of productive employment and decent work is one of the biggest challenges for low- and middle-income countries. According to UNDP estimates, 668 million jobs need to be created in developing countries between 2010 and 2030 to achieve target unemployment rates of at or below 4 per cent for adults and at or below 8 per cent for youth (Bloom \& McKenna, 2015). Demographic pressures make employment creation a particular urgent topic in South Asia and sub-Saharan Africa where a large working-age population is entering the labour market.

The challenge is not only to create new jobs but also to generate quality employment. Decent work - defined as "productive work in which rights are protected, which generates an adequate income, with adequate social protection" (ILO, 1999) - is central to individual and societal well-being. Changes in labour earnings are found to be the largest contributor to poverty reduction (Azevedo et al., 2013; Inchauste et al., 2012). Beyond its fundamental and immediate contribution to household income, employment also affects other dimensions of well-being, such as self-esteem, mental and physical health, and social cohesion.

Many existing jobs lack features of decent work. In 2017, around 300 million workers in developing and emerging countries lived in extreme poverty, on less than Int. $\$ 1.90$ a day (ILO, 2018). Unequal labour market opportunities and outcomes for women persist. With 17 fatal accidents per 100,000 persons in the labour force, the rate in sub-Saharan Africa is more than five times higher than in Europe (ILO, 2019a). Only $30 \%$ of workers in the world are covered with basic occupational health services, mostly workers in large enterprises in the formal sector (WHO, 2018).

Recognising the importance of employment and decent work, the international community has introduced Goal 8 which aims to "promote sustained, inclusive and sustainable economic growth, full and productive employment and decent work for all" (UN, 2015) in the 2030 Agenda for Sustainable Development. Yet, to paint an accurate picture of the employment 
situation in low-and middle-income economies, the labour market specificities in these countries have to be taken into account. Almost half of all workers in developing countries are engaged in small-scale agriculture or self-employment. The vast majority of those in selfemployment run an enterprise with no paid employees (own-account worker). The employment share of micro enterprises is particularly large in Latin America and sub-Saharan Africa, accounting for almost 40 per cent of employment in manufacturing in Chile up to 94 per cent in Ethiopia (World Bank, 2012). Most micro and small enterprises (MSEs) operate in the informal sector, which accounts for up to two-thirds of economic activity in developing countries (La Porta \& Shleifer, 2008).

These characteristics of labour markets in low- and middle-income economies, in particular the importance of MSEs, are not adequately reflected in many standard labour market indicators. For instance, much effort goes into measuring unemployment rates. However, this is not a very informative indicator in countries where the majority of the labour force is not salaried (World Bank, 2012). Indicator 8.3.1 in the global indicator framework for the Sustainable Development Goals measures the proportion of informal employment in nonagriculture despite large evidence for the heterogeneity of the informal sector and considerable doubts about the benefits of formalization for micro- and small firms (Bruhn \& McKenzie, 2014). As these two examples illustrate, much of the conventional wisdom and policy debate on employment generation in developing countries is based on an incomplete picture, ignoring the role played by (informal) MSEs. This is mainly the result of lacking data on MSEs. In recent years, however, panel data on MSEs have become widely available and have allowed researchers to revisit MSE dynamics.

The high prevalence of MSEs and their potential to generate employment in low-and middle-income countries motivates further research on their dynamic behaviour. Rethinking employment and decent work in the context of micro and small enterprises may also redefine the employment-related development goals we want to set and achieve. While recent evidence points to the constraints that hinder MSEs to graduate into medium and large firms, this thesis documents how some MSEs have managed to overcome the existing constraints and market imperfections. In doing so, it highlights further need for policy responses to address market imperfections, also outside the labour market.

\subsection{Employment and micro and small enterprises}

Early literature on the informal sector already pointed to its heterogeneous forms of production (Hart, 1973). Subsequent research has invested much effort in defining and measuring the 
informal sector (Mead \& Morrisson, 1996). While these studies painted a more nuanced picture of the informal sector it contributed little to explaining firm dynamics. Only during the last 15 years, improved availability of panel data on (informal) firms in developing countries has given rise to a renewed research interest in MSE dynamics. Moving away from the informal sector debate, the firm became again unit of analysis. Fields (2005) and others (i.e. Nichter \& Goldmark, 2009) argued that the informal sector comprised an "upper tier", those who voluntarily choose to be informal, and a "lower tier", consisting of survival entrepreneurs. This view on informal sector heterogeneity was extended by the identification of a third group of entrepreneurs, termed "constrained gazelles". These firms share many characteristics with businesses of the upper tier but operate with substantially lower capital stocks (Grimm et al., 2012). Their capital stock is comparable to that of most survivalists. However, they are much more productive and have therefore the potential to earn much higher returns. Thus, a substantial proportion of informal MSEs are more entrepreneurial and have better growth prospects than previously assumed. Understanding the constraints that hinder these firms to grow and the inefficiencies arising thereof is therefore key to unleash the potential of MSEs to generate economic growth and employment generation. The thesis at hand contributes to this line of study.

The literature has identified economic, institutional, social, and individual constraints. Among the economic constraints, credit market imperfections, entry barriers, limited linkages to the formal sector and international markets, and risk have been studied. The existence of "constrained gazelles" is in line with empirical evidence of high marginal returns to capital for some MSEs. Non-experimental (Dodlova et al., 2015; Grimm et al., 2011; McKenzie \& Woodruff, 2006; Udry \& Anagol, 2006), quasi-experimental (Kremer et al., 2011) as well as experimental studies (De Mel et al., 2008; Fafchamps et al., 2011; McKenzie \& Woodruff, 2008) consistently find high returns to capital for MSEs in low- and middle-income countries. Returns typically exceed market interest rates and are highest at low levels of capital stock. There is substantial heterogeneity in returns. Dodlova et al. (2015) find very high returns at low levels of capital, close to zero returns at medium - and relatively high returns at high levels of capital. Returns to capital are generally higher for male, poor and more able entrepreneurs, with few other wageworkers in the household. These results are consistent with the presence of credit constraints. Otherwise, a profit-maximising entrepreneur would borrow to increase the capital stock until marginal returns equate the market interest rate. Yet, credit constraints alone cannot explain the observed high returns to capital. Successful entrepreneurs should be able and willing 
to reinvest a part of their high returns into their business, thereby overcoming credit constraints, accumulating capital and bringing down marginal returns.

Non-convex production technologies in combination with credit market imperfections may deter this possibility. If profitable entrepreneurial activities require a certain indivisible amount of initial investment low-wealth individuals without access to the credit market may be barred from entry. In such a setting, they are limited to activities with low start-up costs but yielding low returns. As a result, the whole economy may end up in a poverty trap (Banerjee \& Newman, 1993). Grimm et al. (2011) examine whether high start-up costs in combination with credit constraints act as entry barriers for small-scale entrepreneurs. They show that activities in some industries require substantial investment in equipment and non-labour expenses, whereas they are negligible in other sectors. Using data from micro enterprises in Mexico, McKenzie and Woodruff (2006) find low median investment levels of new firms in some sectors and very high marginal returns to capital at low levels of capital stock. These results suggest that non-convex production technologies play no decisive role in preventing entry and growth.

Linkages to the formal sector and to international markets may help informal MSEs to expand access to production factors, managerial and technological skills. Thus, the heterogeneity of informal MSEs may in part also be explained by the varying extent of productive and consumptive linkages with the formal sector. Boehme and Thiele (2014) analyse in how far micro enterprises in six West African urban centres are engaged with the formal sector. They show that strong linkages between the formal and the informal sector exist, with backward linkages being more prevalent than forward linkages. Furthermore, linkages vary with the degree of informality, occurring less frequently if firms are unregistered or have low capital stock. Firm performance of informal MSEs is positively correlated with the existence of formal backward linkages. Little is known about the factors that determine the integration of MSEs into international markets and how this affects MSE productivity and production technology.

Dodlova (2015) identify risk as another major impediment to firm growth. They show that the presence of risk leads to considerably lower capital stocks and a slower process of capital accumulation for a sample of Peruvian micro enterprises. Capital market imperfections reinforce the negative effect of risk on firm growth. Hence, entrepreneurs may forego profitable investments because they have to hold cash to cope with shocks and ill-functioning insurance and credit markets. In contrast, De Mel et al. (2008) find no effect of risk on returns to capital. 
Another set of constraints to firm growth relates to the institutional, policy and regulatory framework in developing countries. A growing number of empirical studies at the firm level shows that the inadequate provision of public infrastructure and services, corruption and tax payments negatively affect enterprise performance (e.g. Fisman \& Svensson, 2007; Reinikka \& Svensson, 1999). They further find that these effects differ by firm size (Aterido et al., 2011). Yet, empirical evidence for MSEs is scarce and the results inconclusive. For example, Grimm et al. (2012a) find that access to infrastructure services does not significantly affect MSE performance. However, for a more homogenous sample of tailors in Ouagadougou, electricity exerts a significant and positive influence on firm performance. They argue that this result is rooted in the heterogeneity, and thus the varying need for public services, in the informal sector. In a survey of urban, informal enterprises in West Africa, only 4 per cent of the firms reported having paid a bribe in the year prior to the survey (Lavallée \& Roubaud, 2019). In this study, bribery increases firms' turnover (but not value-added) for enterprises defined as "constrained gazelles". Related to the institutional context is the debate on the benefits of formalization for micro and small enterprises (Bruhn \& McKenzie, 2014). Most studies conclude that the effect on firm performance is at best modest.

Sharing obligations or "forced solidarity" may be another reason for low reinvestment rates among MSEs. There is empirical evidence that successful entrepreneurs try to hide their income from kin (Baland et al., 2011; Di Falco \& Bulte, 2011; Hadnes et al., 2013). More directly, Grimm et al. (2013) show that kinship size is on average associated with higher transfers to the kin and the amount of transfers in turn is correlated with reduced investment for tailoring businesses in Burkina Faso. At the same time, the social network may positively affect business outcomes by providing credit, labour and insurance. Chapter 3 and 4 of this thesis provide evidence for these ambivalent effects.

Last but not least, individual characteristics of the entrepreneur have been identified as important predictors of MSE performance. Mead and Liedholm (1998) found a significantly slower average rate of employment growth in female-headed firms compared to those run by males. In addition, cash grants substantially increased firm profits in male-owned businesses but had on average no effect on female-headed enterprises (De Mel et al., 2008; Fafchamps et al., 2011).

The evidence regarding the impact of education on MSE growth is mixed (Mead \& Liedholm, 1998; Söderbom \& Teal, 2001). Positive effects of education on firm performance seem to materialize only after a certain country-specific threshold is reached (McKenzie \& Woodruff, 2006; Nichter \& Goldmark, 2009). Sound empirical evidence on the effect of 
behavioural aspects, such as a lack of self-control or time-inconsistent preferences, on firm performance is still largely absent (for some tentative explanations see e.g. Fafchamps et al., 2014).

The above-discussed factors are shown to affect the investment behaviour of MSEs. If investment levels are determined by other aspects than the marginal product of capital, allocative inefficiencies may arise. Banerjee and Munshi (2004) document the existence of these inefficiencies caused by network effects in the knitted garment industry in a town in Southern India. Although businesses run by one community, the Outsiders, exhibit higher productivity, firms owned by another community, the Gounders, invest more and produce more capital intensive. The authors discuss several explanations for this investment pattern and conclude that the Gounders face a lower opportunity cost of capital due to their social network. In chapter 4, we present similar findings for MSEs in Colombo, Sri Lanka. This behaviour implies efficiency and equity costs (Fafchamps, 2001a).

While MSEs and their owners have received increasing attention in empirical research, little is known about the workers in these establishments and their working conditions. Monteith and Giesbert (2016) investigate what features of "good work" are valued by workers in informal MSEs in the capitals of Uganda, Burkina Faso and Sri Lanka. Focus Group Discussions revealed that workers appreciate a combination of instrumental characteristics of work, such as income, health and safety, and intrinsic aspects, such as relationships and recognition. There is hardly any empirical evidence illustrating how the (often only implicitly stated) terms of a working contract in MSEs in developing countries are established. In Chapter 5, we shed some light on wage setting in this context, showing that wages move with profits.

\subsection{Contribution to the literature}

This thesis starts out with some conceptual considerations about the components of employment and decent work that should be reflected in an international development agenda. Amidst the discussion about the design of the post-2015 agenda, Chapter 2, entitled "SMARTer indicators for decent work in a post-2015 development agenda: a proposal", revisits the employmentrelated target postulated in the Millennium Development Goals (MDGs) and its corresponding indicators. Measurement problems, the inappropriate use of aggregate statistics, ambiguous interpretability, and assumptions, which often do not hold true in the context of developing countries, are identified as major shortcomings of the MDG indicators. In particular, the discrimination against self-employment inherent in some indicators is not based on firm empirical grounds. Based on these critical reflections, we propose four indicators under the 
employment target "to achieve full and productive employment and decent work for all": (i) the growth of labour value added per worker, (ii) the working poverty rate, (iii) (a) the share of workers receiving less than an absolute labour income and (b) the share of workers receiving less than 60 per cent of the median labour income. These indicators put emphasis on the equality of labour outcomes, an aspect that was largely neglected in the MDGs.

We illustrate the empirical application of the indicators using national household survey data from Uganda and Peru. In the two case countries, our results clearly reveal both a lack of decent work in terms of decent pay and the associated problem of unequal labour incomes. Our empirical exercises also shed light on data limitations and suggest some possible areas of improvement in the provision of standardized micro data.

When this paper was written the discussion about the design of a post-2015 agenda was in full swing and our contribution added to the proposals on targets and indicators for the Sustainable Development Goals (SDGs). In the meantime, the UN General Assembly adopted the 2030 Agenda for Sustainable Development in September 2015. Employment and decent work feature prominently in the Agenda. They are subject of Goal 8 to "promote sustained, inclusive and sustainable economic growth, full and productive employment and decent work for all". Ten targets, of which six are directly related to employment and decent work, are subsumed under this goal. In particular, the qualitative dimension of work has received greater attention through the inclusion of targets relating to the prohibition of forced and child labour as well as the enforcement of labour rights, occupational health and safety. Fifteen indicators have been formulated to measure progress on the employment targets. Unfortunately, many weak points of the MDG indicators have not been addressed.

The continued discrimination against own-account - and contributing family workers and against the informal sector more general motivates a closer look at MSEs and their workers. Therefore, Chapter 3-5 deal with MSEs in the urban sector in developing countries. Chapter 3 provides further evidence for the heterogeneity of the informal sector by reviewing the literature on minority-owned businesses in developing countries. In many low- and middle-income economies, certain economic activities or even the private sector at large are dominated by ethnic minorities. Different disciplines - such as sociology, anthropology, economics and geography - have studied this phenomenon, typically focusing on explanatory factors close to the respective disciplinary background. Our contribution reviews all theoretical arguments and empirical evidence explaining the successful performance of minority-run businesses. We show that in the presence of ill-functioning factor and product markets, informal institutions, such as (ethnic) business networks, gain importance. In fact, network effects can largely explain the 
economic dominance of minority-owned businesses. Social networks reduce transaction costs and enable contract enforcement by circulating information on contractual performance and by coordinating the punishment of cheaters. If information flows primarily between members of a particular ethnic or religious group such a referral system is likely to result in ethnically concentrated business networks. Furthermore, self-selection, settlement policies and colonial history were conducive factors for the emergence of immigrant minority communities. Once these business networks have been established, statistical discrimination against outsiders may arise. Statistical discrimination and network effects reinforce the initial advantages of minority groups and can thus lead to long-term market dominance. This may result in an inefficient allocation of production factors and produce social tension. Our discussion of strategies used by minority-owned businesses to overcome market imperfections points to some fields for policy interventions, such as reducing information asymmetries.

Chapter 4 provides further empirical evidence for the importance of capital constraints for MSEs and the implied inefficiencies. Using panel data of about 500 urban MSEs in Sri Lanka, we investigate the difference in capital stock and production technologies between firms with unrestricted access to the formal credit market, firms that are formally credit constrained but have received loans from family and friends, and firms that have neither access to formal nor to informal credit. Access to family finance is significantly correlated with higher capital stocks, capital-labour ratios and capital-output ratios for the sample of formally credit-constrained firms only. We find that credit-constrained firms with access to family finance are able to adjust their capital stock and production technologies over time to those of firms with access to formal finance. This implies that loans from family and friends can act, to some extent, as a substitute for formal credit. Firms without access to formal and informal finance operate with suboptimal capital stocks. Furthermore, the use of family labour significantly reduces the capital-labour ratio for credit-constrained firms.

Taken together, these results suggest important allocative inefficiencies. Access to production factors significantly determine how much a firm will invest. Credit-constrained firms without access to informal finance display the lowest capital stock and capital intensity of production. At the same time, they seem to use capital more efficiently than unconstrained firms do. Thus, efficiency losses would be reduced if capital could be shifted from unconstrained to credit-constrained firms. A similar observation can be made for the use of labour in the production process. If credit-constrained firms already operate with suboptimal capital stocks and consequently have low capital-labour ratios an increased use of family labour indicates even higher efficiency losses. This discussion of inefficiencies documents some of the 
economic costs and inequalities generated by ill-functioning factor markets. The strategies used by some entrepreneurs to circumvent these market failures hint at intervention areas for policy (e.g. reducing information asymmetries to mimic the benefits of social network membership) to make markets work better for the poor and excluded.

Despite the important role of MSEs in generating employment in developing countries, their workforce has rarely been subject of empirical research. Therefore, in Chapter 5, we turn our attention to the worker and examine whether higher firm profits translate into higher wages for employees of MSEs in urban Uganda. We indeed find a robust and significantly positive correlation between profits and workers' wages. This again documents the presence of (labour) market failures in developing countries. In a perfectly competitive labour market, firm characteristics should not affect wages. The estimated rent sharing elasticities are substantially higher than those found in the most recent papers for developed economies. We further examine the mechanisms through which firm profits may affect workers' wages. Three such mechanisms are discussed in the literature: rent sharing, risk sharing and efficiency wages. We find some suggestive evidence for risk sharing but cannot conclusively establish the underlying mechanism at work. Nevertheless, the significantly positive effect of firm performance on workers' wages suggests that employees of MSEs also benefit from policy interventions aimed primarily at increasing business growth.

This thesis takes micro and small enterprises to the centre of the debate on employment and decent work in developing countries. It provides further empirical evidence showing that MSEs in developing countries operate in imperfect factor and product markets. It particularly focuses on the economic constraints and illustrates the allocative inefficiencies arising due to these market imperfections. By demonstrating how some entrepreneurs are able to circumvent the constraints posed by ill-functioning markets, it helps to identify policy interventions to remove the most binding constraints for MSEs. 


\title{
CHAPTER 2
}

\section{SMARTer indicators for decent work in a post-2015 development agenda: A proposal}

\author{
Martin Ostermeier, Sarah Linde, Jann Lay and Sebastian Prediger \\ This chapter appeared as Ostermeier, M., S. Linde, J. Lay and S. Prediger (2015). \\ SMARTer indicators for decent work in a post-2015 development agenda: A proposal. \\ International Labour Review
}

\begin{abstract}
The MDG employment indicators suffer from major shortcomings, including measurement problems, inappropriate use of aggregate statistics, ambiguous interpretability, and assumptions that do not apply to developing countries. Based on this critique, the authors propose a new set of four indicators for productive employment and decent work, namely: the growth of labour value added per worker, the working poverty rate, the share of workers receiving less than an absolute labour income, and the share of workers receiving less than 60 per cent of the median labour income. They demonstrate the empirical application of these indicators using the country cases of Uganda and Peru.
\end{abstract}

Acknowledgements: The authors gratefully acknowledge funding by the Federal Ministry for Economic Cooperation and Development (BMZ) within the framework of the project "Employment, Empowerment and Living Standards", implemented in cooperation with the German Development Bank (KfW). Additional financial support by the European Union under the 7th Research Framework Programme (NOPOOR project, Theme SSH.2011.1, Grant Agreement No. 290752) is also gratefully acknowledged. The authors wish to thank Holger Seebens and Julia Kubny for discussions on an earlier draft of this article, and participants in the NOPOOR project, the ICDD Annual Thematic Conference 2014, the PEGNet Conference 2014, and the internal GIGA seminar for their helpful comments. The findings, interpretations and conclusions presented in this article are entirely those of the authors and do not necessarily represent the views of BMZ, KfW, the EU or ILO. 
Employment is the main determinant of living standards (World Bank, 2012). It is also of paramount importance for economic development. Quantitative analyses confirm that rising labour earnings are the largest contributor to poverty reduction (Azevedo et al., 2013). Beyond its fundamental and immediate contribution to household income, employment also affects other dimensions of individual and societal well-being, including self-esteem, mental and physical health, and social cohesion.

Recognizing that decent and productive work is central to human and economic development, a new employment target was incorporated into the Millennium Development Goals (MDGs) in 2008 (Target 1.B). Four quantitative indicators were developed to measure progress towards this target. A fifth employment-related indicator relates to Target 3.A, on the promotion of gender equality and women's empowerment. With the MDG deadline approaching, the international community has been intensively discussing the structure and content of the Sustainable Development Goals (SDGs), which will build upon the MDGs and converge with the post-2015 development agenda (ECOSOC, 2014). For the purposes of this article, the most relevant SDG proposal is the one made by the United Nations Open Working Group on Sustainable Development Goals (2014), whose goal 8 aims to "promote sustained, inclusive and sustainable economic growth, full and productive employment and decent work for all”. Besides this Working Group, several other institutions and development practitioners have formulated proposals for employment-related targets and indicators in a post-2015 development agenda (Bates-Earner et al., 2012; ILO, 2012a, 2013; Martins \& Takeuchi, 2013).

This article contributes to the debate by proposing indicators for the measurement of employment outcomes in a post-2015 framework. To this end, it discusses the conceptual foundations of decent work and critically reflects on the current MDG indicators related to employment (ILO, 2009; Sparreboom \& Albee, 2011). Measurement problems, the inappropriate use of aggregate statistics, ambiguous interpretability, and assumptions that often do not hold true in the context of developing countries are identified as major shortcomings of the MDG indicators. In particular, we argue that the discrimination against self-employment and family-employment, implicit in the ILO's definition of vulnerable employment and in the MDG indicators, is misplaced and not based on firm empirical grounds. This is also one of the reasons why social protection would be better dealt with as a separate goal focusing on population coverage by basic social security benefits. Although social protection is one of the pillars of the ILO's Decent Work Agenda, it does not necessarily have to be considered in the context of employment. 
Our critique is followed by a proposal for a new employment-related target and corresponding indicators for the post-2015 development agenda. Such a target should focus on the quality of employment and include an equity component. It should be operationalized through indicators that are specific, measurable, achievable, relevant and time-bound. The proposed four indicators are (i) the growth of labour value added per worker, (ii) the working poverty rate and (iii) the share of workers receiving less than (a) an absolute and (b) a relative minimum labour income. Their empirical application is illustrated using the country cases of Uganda and Peru.

\subsection{Conceptual Considerations}

This section relates the MDG employment targets to some of the main dimensions of employment and decent work, as understood by the ILO. Our discussion highlights different properties of employment that should ideally be captured by indicators. Particular attention is paid to the definition of vulnerable employment and the possibilities of linking employment with social protection in the post-2015 development agenda. We then present a set of technical requirements for formulating conceptually valid and feasible indicators.

\subsubsection{Foundations and challenges of employment-related development targets}

Under MDG 1, Target 1.B seeks to "achieve full and productive employment and decent work for all, including women and young people" (UN, 2008). This target incorporates three aspects of employment:

- quantity of employment: full employment for all,

- quality of employment: productive employment and decent work, and

- equity of employment opportunities: including women and young people (Martins \& Takeuchi, 2013, p. 3).

Full employment is a standard economic concept, requiring that all people who are available, capable and willing to work are able to do so. Yet, the quantity aspect of employment also refers to participation in the labour market: some people, particularly women, may not even be actively seeking work - the prerequisite for being considered unemployed and thus participating - despite being available, capable and willing to work. In general, the importance of both of these quantitative dimensions of employment - i.e. labour force participation and 
unemployment - depends on a country's level of development and country-specific labour market conditions. ${ }^{1}$

The quality of employment is described by the attributes "productive" and "decent". Productive employment can be defined as "employment yielding sufficient returns to labour to permit the worker and her/his dependents a level of consumption above the poverty line" (ILO, 2012b). Thus, the productive employment deficit is comprised of the unemployed and the working poor, who are unable to attain a minimum consumption level despite being employed. Decent work is a more comprehensive concept and is understood as "productive work in which rights are protected, which generates an adequate income, with adequate social protection" (ILO, 1999). Under social protection the ILO subsumes the coverage and effectiveness of social security schemes, and labour protection "which comprises decent conditions of work, including wages, working time and occupational safety and health" (ILO, 2014).

Finally, the MDG employment target considers equity aspects, stressing the exclusion of specific groups - here women and the young - from full and productive work. While this is doubtlessly relevant, the focus on the inequality of opportunities rather than outcomes is too narrow. Indeed, feedback mechanisms from outcomes to opportunities - e.g. low wages that cause little investment in human capital - require that an employment target should also take account of the distribution of outcomes, such as equality of labour earnings.

\subsubsection{The relationship between employment and social protection}

Non-decent employment conditions can place people at economic and personal risk. Thus, there is a rationale for linking employment and social protection in the post-2015 development agenda, and many proposals do indeed incorporate measures of social protection. Yet, from a conceptual point of view, including social security (e.g. coverage by health, old age and/or unemployment benefits) under an employment goal is appropriate only if related measures directly inform about the decency of work. This is the case if social security benefits are directly tied to the employment relationship. However, this typically applies only to workers in wage employment. Another, more practical problem is the diverse and context-specific nature of social protection systems and working arrangements.

\footnotetext{
${ }^{1}$ This article uses the definitions of work and employment adopted by the 19th International Conference of Labour Statisticians in 2013 (see ILO, 2013b). In previous statistical practice (applied when the MDGs were drafted), persons engaged in the production of economic goods and services for own and household consumption were considered to be in self-employment and, therefore, employed, whereas persons (notably women) doing household work were considered not to be in the labour force. Under the current rules, both groups are defined as outside the labour force, but in the "potential labour force".
} 


\subsubsection{SMART indicators}

The challenge in measuring decent work is to find indicators that can meaningfully capture all three dimensions of the employment target by combining relevance in terms of decent work with practical realism (particularly in terms of actually collecting and managing the required data). A widely used and internationally recognized set of formal requirements to assess the quality of indicators are the so-called SMART criteria. These are presented in Table 1.

Table 1: The SMART criteria

\begin{tabular}{|c|c|}
\hline Specific & $\begin{array}{l}\text { The indicator must ensure a clear and unambiguous interpretation and } \\
\text { should be a true translation of the target so that the changes measured by the } \\
\text { indicator genuinely express the targeted improvement. }\end{array}$ \\
\hline Measurable & $\begin{array}{l}\text { The indicator must be (easily) measurable and deliver reliable (hence } \\
\text { replicable) data, no matter who conducts the measurement. It should rely on } \\
\text { common data already collected within the scope of the country's statistical } \\
\text { strategy (e.g. national household surveys or labour force surveys). For inter- } \\
\text { temporal and cross-country comparability, it is essential that the data } \\
\text { sources, collection and preparation methods, and the final analysis comply } \\
\text { with international standards. Moreover, definitions and methodologies have } \\
\text { to be consistent over time. }\end{array}$ \\
\hline
\end{tabular}

\begin{tabular}{ll}
\hline Achievable & The set aspiration level of the indicator must be achievable. Unduly low \\
target values can suggest evident results but are not useful for measuring the \\
effectiveness of the project, programme or policy.
\end{tabular}

Relevant The information provided by the indicator must deliver important information for decision-makers. In the case of employment-related indicators, this refers primarily to national governments, but also to the international community and individual workers or trade unions.

Timely/Time-bound The indicator must specify a deadline or time frame.

Source: Authors compilation after (European Commission, 2004; UNDP, 2009)

\subsection{A critical review of the employment-related MDG indicators}

\subsubsection{The growth rate of labour productivity}

The first employment-related indicator of the MDGs addresses the creation of productive employment by measuring the annual growth rate of GDP per person employed. ${ }^{2}$ The rationale for including labour productivity in the set of MDG indicators is its close and positive

\footnotetext{
${ }^{2}$ A general problem in linking production and employment is the possible discrepancy between output measured by national accounts and people in work (but not employed) who generate output. While housework (unpaid, at home) is neither considered as employment nor measured in national accounts, this may be different for the selfemployed and (part of) their produce. For example, smallholder production - though it may (partially) be for household consumption - is within the national accounts production boundary.
} 
relationship with wages. According to neoclassical theory, wages equal marginal labour productivity. Empirical studies confirm a close - albeit far from perfect - relationship between wages and labour productivity (Luebker, 2011, p. 15).

Nevertheless, labour productivity growth presents several drawbacks that limit its validity as a measure of productive employment. Most importantly, in a significant number of developing economies, other production factors - particularly natural resources and land generate a considerable share of value added, with factor income being earned by their respective owners. In more developed economies with high capital-to-labour ratios, GDP growth may be driven mainly by capital accumulation (not necessarily higher returns), and the earned factor incomes then typically accrue to capital owners. This implies that levels of labour productivity - not to mention growth rates - can only be meaningfully compared across economies that share similar factor endowments and sectoral compositions.

Furthermore, labour productivity only makes a relevant measure of decent pay if there are no large differences in labour productivity and corresponding wages between workers. Many poor economies, however, may employ highly productive labour with high wages in some sectors (e.g. mining), while a large share of their workforce is engaged in low-productivity and low-wage occupations, such as subsistence agriculture and work in the urban informal sector. Wide wage differentials may also occur within sectors. In consequence, GDP growth rates may increase without any improvement of labour productivity and wages across large segments of the workforce.

\subsubsection{Employment to population ratio}

The employment-to-population ratio (EPR) is the share of a country's working-age population that is actually employed. This indicator measures an economy's ability to provide employment for those people who are able to work, i.e. the extent to which full employment is achieved. The ILO (2009) suggests a value range from 50 to 75 per cent. Yet, the lack of a clear target value or even a guideline for the EPR renders the interpretation of this indicator difficult and ambiguous, particularly in the context of developing economies. For example, a high EPR may result from a low unemployment rate, which might, in turn, be the sign of a well-functioning and rapidly clearing labour market. However, low registered unemployment can also be a reflection of the lack of social support systems, let alone unemployment insurance, as is the case in many poor economies. People in such circumstances cannot afford to be unemployed and have to work for survival. Whether their work is counted as "employment" will then depend on the market-orientation of what they do for a living, i.e. whether it is done in exchange for 
pay or profit. Similarly, in economies dominated by smallholder agriculture, a high rate of labour market participation and, consequently, a high EPR do not signal ample labour market opportunities, but rather that all available labour is required to operate the household farm. Finally, an EPR may also be low because a substantial share of the working age population is out of the labour force attending school or university. Taken together, these ambiguities make the EPR a dubious indicator that can hardly be expected to provide reliable information on progress towards full employment.

\subsubsection{Working poverty rate}

The ILO (2009) defines the working poverty rate (WPR) as the proportion of employed people living in a household with a per capita income below the nationally defined poverty line (or the international poverty lines of Int.\$1.25 or 2 per day). The WPR provides a measure of productive employment by linking poverty and employment data. It represents the share of workers whose jobs do not generate sufficient income to lift them and their families out of poverty. Although this indicator explicitly considers only the income dimension of decent work, it implicitly provides a broader picture: it is reasonable to assume that jobs which provide people with insufficient means to meet their basic needs are unlikely to fulfil other requirements of decent work (ILO, 2009). Yet, working poverty may be caused by factors other than low pay (e.g. number of dependents), while other sources of income might mask low labour earnings (e.g. remittances and government transfers).

In principle, the WPR can be readily computed from micro datasets that provide information on poverty status at the household level and employment at the individual level. In practice, however, the WPR has often been calculated using aggregate statistics, as the product of the poverty rate and the labour force participation rate (LFPR) (macroeconomic approach). This simplification has been justified by a lack of micro data but entails important drawbacks. The neglect of differences in demographic composition and labour force participation rates among poor and non-poor households results in biased estimates of the country-level incidence of working poverty. Using data for 15 sub-Saharan African countries, Kapsos (2011) finds an average difference of 8.6 percentage points between the macro- and the micro-based WPR estimates. Finally, this indicator suffers from the general drawbacks of a headcount index in that it does not account for intra-household inequality or the depth of poverty. It is also plagued by the problems related to the definition of national and (more so) international poverty lines. ${ }^{3}$

\footnotetext{
${ }^{3}$ The literature has identified challenges arising from different consumption patterns across countries/regions, the 2005 PPP factors based on 1988-2005 prices and changing basic needs, the strong bias towards African countries
} 


\subsubsection{Vulnerable employment rate}

According to the ILO (2009), the vulnerable employment rate is the proportion of own-account and contributing family workers in total employment. Based on their employment status, these two categories of workers are termed vulnerable because they are believed to face high economic risks. Own-account workers and contributing family workers are assumed to be less likely to have formal work arrangements, and thus often to lack elements of decent work, such as adequate social security and effective social dialogue mechanisms (Sparreboom \& Albee, 2011). Additionally, own-account workers in developing countries are typically perceived to earn a low and irregular income since they are mostly subsistence farmers and small-scale entrepreneurs operating in the informal economy. Indeed, in many cases, contributing family workers receive neither payment in cash nor remuneration in kind, but benefit indirectly from an increased household income.

However, the assumption that self-employed (family) workers are per se more vulnerable than employees is problematic, thus calling into question the specificity and relevance of the "vulnerable employment" indicator. Own-account workers and the associated category of contributing family members form a very heterogeneous group in developing countries. It includes not only those engaged in agricultural and urban informal subsistence activities, but also those running productive and profitable micro enterprises. In fact, research has shown that self-employment is often - albeit not always, and conditional on context chosen voluntarily (Maloney, 2004). Furthermore, in many developing countries wage workers (not to mention casual or seasonal workers) are not covered by social protection and do not have legally enforceable contracts of employment, which might render their conditions just as precarious as those of some own-account and contributing family workers. Thus, vulnerable employment would better be defined in terms of employment conditions, rather than employment status.

\subsubsection{Share of women in wage employment in the non-agricultural sector}

This last employment-related indicator of the MDGs is part of the gender equality goal and can be found under target $3 \mathrm{~A}$, which aims to "eliminate gender disparity in primary and secondary education, preferably by 2005 , and in all levels of education no later than 2015 ". The share of

(only two out of the 15 poorest countries are in Asia), and urban bias because internationally comparable services and goods are mainly found in urban areas. For a detailed critique and the implications for Asian poverty calculations, see ADB (2014). 
women in paid employment in the non-agricultural sector is expressed as the percentage of female workers in total non-agricultural wage employment.

The ratio of women in wage employment in the manufacturing and service sectors is meant to provide an indication of the extent to which female workers have access to the modern monetary economy and thus benefit from the structural transition of the economy. The underlying assumption is that women in such wage employment enjoy greater autonomy and self-reliance in personal development and decision-making (ILO, 2009, p. 31). While there is indeed some evidence that wage employment outside agriculture improves the situation of women (Kabeer, 2005), the general discrimination against self-employment is subject to the same criticism as that expressed above in regard to "vulnerable employment". Furthermore, the indicator ignores the value that women may attach to the flexibility afforded by work on a household farm or in a household enterprise. Indeed, wage employment may not only bring about positive changes in women's lives. Since women typically continue to be responsible for domestic work and child care, gender inequalities in work burdens may intensify (Kabeer, 2005).

\subsection{Proposal for a new employment target and set of indicators}

In general, the multi-dimensional formulation of both the MDG employment target and the Open Working Group's current proposal is an important strength. It avoids some of the criticisms levelled at other MDG targets, such as a lack of focus on quality (e.g. Target 2.A on full primary education) and the general absence of (any) equity considerations. Accordingly, a future employment target should cover quantity, quality and equity aspects. These dimensions can be subsumed into a target to "achieve full and productive employment and decent work for all". The chosen indicators will eventually determine the implicit weightings given to the different aspects of this employment target.

While full employment should be explicitly mentioned in the target, our conceptual considerations and assessment of the EPR demonstrate that the underlying drivers participation and unemployment - would give rise to ambiguities if quantitative aspiration levels were to be formulated. This may preclude the establishment of specific indicators of full employment.

For most qualitative components of decent work, such as wages or occupational safety and health, there are no such ambiguities (although decent working time does raise ambiguities similar to those surrounding labour force participation). However, more practical problems arise when it comes to operationalising the quality of employment, particularly concerning 
occupational safety and health, which may be very industry specific. While good data collection practices can be found, say, in the European Union (Burchell et al., 2014), there are almost no data available for developing countries.

In light of these problems, the indicators proposed below deliberately focus on the income component of decent work. We implicitly assume that income is often highly correlated with non-monetary dimensions of decent work, particularly with occupational safety and health. As regards social protection, we have argued above in favour of setting a separate social protection goal rather than including elements of social protection in an employment target. The corresponding indicators would then not be directly tied to a person's employment relationship but inform about the total population's coverage by social security schemes.

Regarding equity, the proposed indicators emphasize relative labour earnings inequality. While equal pay for equal work is considered important as well, any such indicator would need to identify "pairs of equal work" unambiguously, for comparison. While there are techniques for doing this, their sophistication implies that such an indicator would hardly be suitable for the SDG agenda.

Our proposed indicators are an attempt to overcome some of the weaknesses of the current employment indicators and to explicitly introduce an equity dimension. They are not only conceptually valid but also feasible indicators that allow for the quantitative measurement of progress (or regress) on specific and important aspects of productive employment and decent work. Applying the SMART criteria results in a catalogue of four indicators for our proposed target of "achieving full and productive employment and decent work for all", namely: the growth of labour value added per worker, the working poverty rate, the share of workers receiving less than an absolute labour income, and the share of workers receiving less than 60 per cent of the median labour income.

All four indicators can be disaggregated by sex, age (for a focus on youth) and other groups of interest. Whether other disadvantaged groups - e.g. persons with disabilities or migrants - should be explicitly considered under an employment target is also a question of the general design of the SDGs. Alternatively, cross-cutting issues of discrimination against specific groups could be dealt with under separate targets. This may limit the risk of overloading the "thematic" target (in this case employment). Finally, we suggest that target values should be set nationally in order adequately to reflect country-specific employment challenges and development contexts. 


\subsubsection{Indicator 1: Growth of labour value added per worker}

Labour value added is defined as total labour compensation (including income from selfemployment) over total employment. It captures both the productivity of the worker and the share of production accruing to labour through factor income earned. The growth of labour value added per worker is driven by higher wages, which may, in turn, be the result of higher productivity. The indicator reduces the problem of non-labour income being taken as a sign of productive work. Single industries with large shares of income generated by natural resources or capital do not bias it. A decline in labour value added per worker unambiguously indicates that wages and/or employment creation have not kept pace with economic growth. In countries where labour value added is not provided frequently enough by the national accounts system, it can be approximated by GDP minus factor payments for capital and land, taxes, and tariff revenues. Labour value added can also be calculated from nationally representative household data by dividing total labour earnings by total employment. This microeconomic approach can be considered to yield an upper bound estimate since it includes profits from self-employment under total labour income. ${ }^{4}$ The proposed indicator would be to increase labour value added by a certain country-specific percentage by 2030 .

\subsubsection{Indicator 2: Working poverty rate}

The working poverty rate captures the concept of decent work fairly well in terms of enabling workers and their families to earn a decent livelihood. In addition to using national poverty lines, it should also be reported by reference to the international poverty lines of Int. \$ 1.25 and Int. \$ 2 in order to allow for cross-country comparisons. Regarding its operationalization, the working poverty rate should be computed using household or labour force survey data. The indicator would be to reduce the incidence of working poverty by a certain country-specific percentage by 2030 .

\subsubsection{Indicators 3a and 3b: Proportions of workers earning less than an absolute and a relative minimum labour income}

These two indicators of decent pay represent the proportions of working-age people receiving a labour income below nationally or internationally defined minimum income levels ("minimum labour earnings"). These minimum labour income levels should be specified both

\footnotetext{
${ }^{4}$ Note that household survey data are known to produce much lower estimates of income compared to national accounts (Deaton, 2005). So, while the inclusion of capital income from self-employment induces an upward bias, the very use of micro data implies a downward bias.
} 
in absolute terms (i.e. by reference to the international or national poverty lines) and in relative terms (i.e. 60 per cent of the median labour income). Using an absolute threshold allows for an unambiguous interpretation: labour income levels directly affect one's material livelihood; and, ceteris paribus, higher earned income is preferred over lower earned income. In addition, defining a relative "decent labour income threshold" as a certain percentage of mean or median labour income puts more emphasis on equity since the indicator will not respond to labour income increases that do not affect the distribution of labour earnings.

Conceptually, the mean labour income would be the preferred reference for a relative indicator. It is more sensitive than the median to income gains by the richer segments of the employed workforce. In practice, however, estimates of mean incomes from household or labour force survey data are prone to errors, in particular because of reporting biases in higher incomes. This is why the median labour income is the more robust reference, although the resulting indicator will not respond to changes in the income distribution above the median. We propose to use 60 per cent of the median as the relative threshold; this choice is motivated by the fact that the European Union, for example, considers people below this threshold to be "at risk of poverty". Some caution is warranted when interpreting the proposed relative indicator, particularly when comparing it across countries, because the meaning of the reference income, the median labour income, crucially depends on the shape of the labour income distribution in combination with the structural features of each specific economy. In a country where the median earner is a subsistence farmer or entrepreneur (e.g. in many sub-Saharan African economies), the income distribution below the median will be very flat: probably only a small fraction of people will earn less than 60 per cent of the median labour income because there is little inequality of labour income among a large and fairly poor population. Indeed, there may be preferable situations in terms of well-being when inequality among those below the median labour income is wider. Hence, we propose a combination of absolute and relative indicators.

For the absolute indicator, established per capita poverty thresholds - i.e. national and international poverty lines - can be used to proxy for minimum labour income thresholds. The two indicators would thus be to reduce the share of workers below the absolute and relative thresholds by a country-specific percentage by 2030 .

\subsubsection{SMARTer indicators}

Labour value added growth and the working poverty rate lend themselves to clear, unambiguous interpretation and straightforward formulation of the corresponding country-specific aspiration levels. The same goes for the share of workers earning less than a specified absolute labour 
income, but not for the relative, "equity" indicator. Any such indicator necessarily entails a value judgement on the weight assigned to the welfare of individuals at different quantiles of the distribution of labour earnings. Since only those earning below 60 per cent of the median are taken into account, the implied weight given to the distributional distance to earners of very high incomes is zero.

All our proposed indicators can be measured using available data (e.g. living standard measurement surveys, national household surveys or labour force surveys). It would certainly be desirable to better reflect working conditions in the SDG indicators (with regard to health, safety and hours of work). Yet, it is not conceivable that the necessary data would be available for a sufficient number of countries in the short-term. The lack of detailed comparable data on working conditions thus also explains our focus on income.

Finally, the proposed indicators are clearly relevant, as they can deliver important information for decision-makers. If based on micro data, all four indicators can be broken down, say, by occupation, sector, sex, education, and migration status. This can help to identify groups that are particularly affected by non-decent working conditions. Conditional on the overall setup of the SDGs, specific sub-group indicator values could be derived for each indicator. The indicators relating to labour income can also inform policy interventions, such as the setting of a national minimum wage.

\subsection{Empirical illustration of the proposed indicators}

This section illustrates the application of the proposed indicators using the examples of Uganda and Peru. These two cases are well suited to illustrate the advantages and challenges associated with the proposed indicators in different settings.

Some of Uganda's characteristics make it a suitable representative of the world's lowincome economies, particularly concerning the predominance of the agricultural sector, largely informal urban employment, and a high labour force participation rate. Despite an impressive growth performance in the past 20 years compared to the African average, Uganda is still a lowincome country. Income poverty has been reduced considerably, from over 70 per cent of the population in the early 1990s to about 38 per cent in 2009 (headcount ratio applying the PPP poverty line of Int. \$ 1.25) (World Bank, 2010). According to our calculations based on the Ugandan National Household Survey (UNHS), agricultural and non-agricultural selfemployment have played an important part in this process, as they account for more than twothirds of the country's employment. This does not include other contributing household members on and off the farm, which account for a further 20 per cent of the workforce. While 
the share of urban population has been increasing, it was still below 15 per cent in 2010 . The illustrations given below draw on UNHS data for the years 2005/06 and 2009/10, based on survey samples of about 7,400 households with more than 41,200 individuals in 2005/06, and 6,775 households with more than 36,400 individuals in 2009/10.

Peru is an upper-middle-income economy. Like Uganda, it has enjoyed a good growth performance over the past 15 years, together with a steady decline of its poverty ratio, from 12.4 per cent in 2000 to 4.9 per cent in 2010 (World Bank, 2014). Compared to Uganda, the share of self-employment is lower in Peru and is decreasing slightly since the mid-2000s. Still, over 54 per cent of the workforce was self-employed in 2009. In terms of sectoral composition, Peru has a large service sector accommodating more than 55 per cent of total employment, while Uganda's economy is largely dominated by agricultural activities (73 per cent). These basic characteristics of the Peruvian labour market are comparable not only to those of other Latin American economies with large shares of self-employment, such as Mexico or Colombia, but also to the labour market characteristics of Asian middle-income economies, including Indonesia and Thailand. For Peru, we use household data from the Encuesta Nacional de Hogares (ENAHO) for the years 2005 and 2009. This survey comprised more than 25,600 households (with almost 93,000 individuals) in 2005 and 26,600 households (with over 96,000 individuals) in 2009.

\subsubsection{Growth of labour value added per worker}

Labour value added per worker is computed as the sum of all wages and net profits divided by the number of persons employed. 5 Table 2 shows the growth in labour value added per worker in Uganda and Peru between 2005 and 2009. The estimates are well in line with the overall economic performance of both countries. In Peru, labour value added per worker (in constant LCU $^{6}$ ) grew by about 9 per cent annually between 2005 and 2009 (from a 2005 baseline of Int. $\$ 3,424$ in PPP), while the annual growth rate of gross national income (GNI) per capita was 6.3 per cent (World Bank, 2014). In Uganda, with a per capita income of only Int. \$ 353 in 2005, the estimated annual growth of labour value added per worker (in constant LCU) was 14.1 per cent over the period - considerably higher than the economy's per capita GNI growth rate of only 4.8 per cent (World Bank, 2014). Closer inspection of the Ugandan data reveals

\footnotetext{
${ }^{5}$ We count all smallholders in both Uganda and Peru as employed. While this may partially conflict with the new labour statistics practices, it is in line with the definitions used when the surveys were carried out. Yet, it should be noted that - even in Uganda - the majority of smallholders produces for the market.

${ }^{6}$ LCU refers to local currency units (Peruvian Nuevo Soles and Ugandan Shillings).
} 
that this strong growth was driven by labour value added in agriculture, while labour value added per worker in non-agricultural self-employment actually declined.

Table 2: Labour value added per worker in Uganda and Peru, 2005 and 2009

\begin{tabular}{clccc}
\hline Country & $\mathbf{2 0 0 5}$ & $\mathbf{2 0 0 9}$ & $\begin{array}{c}\text { Annual } \\
\text { Growth } \\
\text { (in \%) }\end{array}$ \\
\hline \multirow{2}{*}{ Uganda } & $\begin{array}{l}\text { (in constant 2005 } \\
\text { Int. \$) } \\
\text { (in constant LCU) }\end{array}$ & 353 & 451 & 6.3 \\
\hline \multirow{2}{*}{ Peru } & (in constant 2005 & 263,009 & 446,320 & 14.1 \\
\hline & Int.\$) & 3,424 & 4,504 & 7.9 \\
& (in constant LCU) & 5,650 & 7,656 & 8.9 \\
\hline
\end{tabular}

Source: Authors' calculations based on UNHS 2005/06 and 2009/10, ENAHO 2005 and 2009.

Note: LCU refers to local currency units (Ugandan Schillings and Peruvian Nuevo Soles).

Technically, the differences between the PPP-adjusted values and the values in local currency for Uganda are noteworthy. The much lower growth rate of labour value added in constant Int. \$ can be explained by major changes in the PPP conversion factors. While the figures in Int. \$ are useful for cross-country comparisons, the analysis of within-country changes over time should be complemented by indicators measured in local currency. Finally, this exercise also illustrates that a meaningful aspiration level for this indicator might be the projected growth rate of GNI per capita.

\subsubsection{Working poverty rate}

In the next step, we compute the incidence of working poverty in Uganda and Peru. Table 3 shows the headcount poverty ratios and the WPRs for both countries in 2005 and 2009, using different approaches. The results of calculations based on national conventions are contrasted with those obtained from the World Bank's approach to computing the internationally comparable poverty rates (applying the 1.25 Int. \$/day poverty line to monitor MDG 1). For the purposes of its official national poverty statistics, Uganda uses a consumption aggregate per adult equivalent and regional poverty lines that further distinguish between rural and urban areas. Peru bases its estimates on consumption per capita and uses regional poverty lines. The regional poverty lines can differ considerably: in Peru, the highest is 52 per cent higher than the lowest, and in Uganda, it is four times higher. Depending on the context, the consideration of equivalence scales and regional price differences is known to matter for measuring poverty and, accordingly, working poverty. While these are only two of the problems raised by the calculation of internationally comparable (working) poverty rates, a more extensive discussion 
of the issues goes beyond the scope of this article. Yet, we consider the advantage of having internationally comparable indicators to outweigh those disadvantages.

Table 3: Working poverty rates in Uganda and Peru, 2005 and 2009

\begin{tabular}{lccccc}
\hline & \multicolumn{2}{c}{ Uganda } & \multicolumn{2}{c}{ Peru } \\
\cline { 3 - 6 } & & $\mathbf{2 0 0 5}$ & $\mathbf{2 0 0 9}$ & $\mathbf{2 0 0 5}$ & $\mathbf{2 0 0 9}$ \\
\hline Poor (headcount - national poverty & $\%$ & 29.3 & 24.5 & 55.6 & 33.5 \\
line) & $\%$ & 44.6 & 35.7 & 5.6 & 2.2 \\
Poor (headcount - Int. \$ 1.25) & $\%$ & 70.1 & 64.4 & 16.8 & 8.7 \\
Poor (headcount - Int. \$2) & $\%$ & 77.0 & 77.7 & 71.7 & 76.9 \\
LFPR & & $9,799,816$ & $11,432,223$ & $13,107,577$ & $15,418,822$ \\
Total number of persons employed & $\%$ & 27.9 & 22.5 & 55.7 & 32.0 \\
WPR (national poverty line) & $\%$ & 45.9 & 29.7 & 5.5 & 2.0 \\
WPR (Int. \$ 1.25) & $\%$ & 73.3 & 60.2 & 17.0 & 8.2 \\
WPR (Int. \$ 2) &
\end{tabular}

Source: Authors' calculations based on UNHS 2005/06 and 2009/10, ENAHO 2005 and 2009.

Table 3 shows that poverty decreased in both countries. The results illustrate the importance of the choice of applied methods and poverty lines. Uganda's national poverty statistics suggest a moderate decline in the headcount ratio between 2005 and 2009. Using the international poverty lines, however, the reduction of extreme poverty (less than Int. \$ 1.25 per capita per day) appears to have been much more pronounced than that of poverty according to the higher poverty line (less than Int. \$2). In Peru, the national poverty line is much higher than the international poverty lines. Albeit at different levels, all of the country's poverty indicators show a drastic decline over the period under consideration.

Some very interesting patterns emerge with regard to the WPR, illustrating the possible value of this indicator as a complement to poverty measures. For Peru, the WPR is very close to the headcount ratio, i.e. the share of poor workers among all workers is similar to the share of poor people in the overall population. This holds for all indicators and both years, implying that progress in poverty reduction correlates with progress in workers' incomes. In Uganda, in contrast, this only applies to 2005. In 2009, the WPR was between two and six percentage points lower than the headcount ratio. This means that the working population fared better than the non-working population and that income from work enabled people to escape poverty more effectively than did other sources of income. This is consistent with the above finding of a considerable increase in labour value added per worker in Uganda. It is also likely to reflect the country's higher labour force participation rate, with more household members contributing to household income with their labour. In general, the fact that overall poverty rates in Uganda are higher than the country's working poverty rates - while being similar in Peru - is likely to be related to differences in the composition of household income sources between the two 
countries. In particular, non-labour incomes (e.g. old-age pensions and other transfers), which partially sustain households without employed individuals, are more common in Peru than in Uganda. In other words, in economies without social support programmes people are more dependent on decent labour income.

\subsubsection{Workers earning less than absolute and relative minimum labour incomes}

As explained above, established per capita poverty thresholds - i.e. national and international poverty lines - are used as proxies for absolute minimum labour income thresholds. To estimate the proportions of employed people earning less than the Int. \$ 1.25 threshold and the proposed relative threshold of 60 per cent of median labour income, we first calculate the total monthly labour income for each employed person. In a developing country context, this poses a number of challenges. One of them is the high incidence of unpaid family workers in household firms (and farms), which is an important feature not only of the Ugandan economy but also of many other developing countries. Unfortunately, the intra-household allocation of profits accruing from such household-level economic activities is not known. In order to obtain income measures for unpaid family workers, we divide household business and farm incomes equally among all household members involved in the productive activity.

Table 4 reports both countries' median monthly labour incomes in 2005 and 2009, as well as the shares of workers aged 15 years and above earning less than the respective thresholds. In line with our previous observations on changes in labour value added and the incidence of working poverty, the figures show that labour earnings increased substantially in both countries in the period under review, although Ugandan workers still had low earnings by the end of the period. Indeed, Uganda's monthly median labour income was Int. \$ 25.8 in 2009, which implies that more than 57 per cent of workers earned less than the absolute threshold of Int. \$ 1.25 per day. This share is down from 64 per cent in 2005, so some progress can also be seen in individual labour earnings in this country. This also holds for Peru, where the share of workers earning less than Int. \$ 1.25 per day declined from 18 to 11.3 per cent over the period. Yet, what is noteworthy in the Peruvian case is that these shares are relatively high when compared to the WPR (5.5. and 2 per cent in 2005 and 2009, respectively). This implies that employed persons with very low labour earnings live in households that have additional sources of income (either other workers with higher labour income or social transfer payments). The difference between the working poverty rate and the minimum labour income indicator is somewhat less pronounced in Uganda. 
Table 4: Workers earning less than absolute/relative thresholds in Uganda and Peru, 2005 and 2009

\begin{tabular}{|c|c|c|c|c|c|}
\hline & & \multicolumn{2}{|c|}{ Uganda } & \multicolumn{2}{|c|}{ Peru } \\
\hline & & 2005 & 2009 & 2005 & 2009 \\
\hline \multirow[b]{2}{*}{$\begin{array}{l}\text { Total monthly labour income } \\
\text { per employed person - median }\end{array}$} & Int. \$ & 19.5 & 25.8 & 159 & 228 \\
\hline & $\begin{array}{l}\text { Constant } \\
\text { LCU } \\
\text { (base=2005) }\end{array}$ & 14,500 & 25,492 & 263 & 388 \\
\hline \multirow[b]{2}{*}{$60 \%$ of the median } & Int. \$ & 11.7 & 15.5 & 95 & 137 \\
\hline & $\begin{array}{l}\text { Constant } \\
\text { LCU } \\
\text { (base=2005) }\end{array}$ & 8,700 & 15,295 & 158 & 233 \\
\hline \multicolumn{6}{|l|}{ Share of workers below... } \\
\hline ... Int. \$ 1.25 (PPP) per day & $\%$ & 63.9 & 57.7 & 18.0 & 11.3 \\
\hline$\ldots 60 \%$ of median income & $\%$ & 37.3 & 36.4 & 36.7 & 36.5 \\
\hline
\end{tabular}

Source: Authors' calculations based on UNHS 2005/06 and 2009/10, ENAHO 2005 and 2009.

Table 4 also reports our estimates of the proportions of workers earning less than 60 per cent of the median incomes in both countries. Somewhat surprisingly, the proportions are very similar in both countries - about 36 per cent - and remained relatively constant over time. In Uganda, however, the relative income threshold was very low - at Int. \$ 11.7 in 2005 and Int. \$ 15.5 in 2009 - so the fact that more than a third of all workers fell below this threshold is striking. Yet, even those with extremely low earnings appear to have benefited from general income growth. At least, their relative position is not deteriorating. There is nonetheless obvious room for improvement, as more than a third of workers earn less than 60 per cent of median earnings in countries where the median earner already earns well below the average.

\subsection{Conclusion}

This article contributes to the discussion of employment-related targets and indicators for the post-2015 development agenda. We propose to measure progress towards a target to "achieve full and productive employment and decent work for all" by using four indicators, namely: the growth of labour value added per worker, the working poverty rate, the share of workers receiving less than an absolute labour income, and the share of workers receiving less than 60 per cent of the median labour income. The suggested target and indicators overcome most of the major limitations of the indicators currently in use and put special emphasis on equity - an aspect that was largely neglected in the MDG agenda. The proposed indicators are conceptually 
valid according to the SMART criteria and allow for the quantitative measurement of progress (or regress) on important aspects of productive employment and decent work. Moreover, the setting of targets at the national level and the possibility of disaggregating each of our proposed indicators by sex, age and other variables of interest to decision-makers allow for the incorporation of additional dimensions of equity and inclusion. Nonetheless, the multidimensionality of decent work implies that neither the currently applied employmentrelated indicators nor those proposed by us are able to capture all of its facets.

A major challenge in measuring decent work stems from the quality, scope, coverage, and periodicity of data collection, since these factors typically impede cross-country comparisons to a large extent. Our proposed indicators are income-focused not because we think that income is a perfect proxy for the quality of work, but because data on conditions of work - e.g. working time and occupational safety and health - are simply not available for a sufficient number of countries. Hence, the urgent need to expand the scope of household and labour force surveys and to harmonize them internationally as they are the main data source for employment indicators. This will require further strengthening of the capacities of national statistical institutes. 


\title{
CHAPTER 3
}

\section{The puzzle of successful minority-run businesses in developing countries: A review}

\author{
Sarah Wiegel
}

\begin{abstract}
In many developing countries, business communities are not representative of the population at large. Minorities, typically immigrants or other members of a particular ethnic or religious group, are overrepresented and particularly successful in entrepreneurship. These businesses typically dominate certain economic sectors; in some countries even private enterprise at large. The success of minorities and the associated dominance of minority-run businesses in developing countries appears to persist over time despite changing political and economic conditions. Their relative success is at odds with the experience of minority-owned businesses in developed economies with entrepreneurs originating from developing or emerging countries. The latter more frequently occupy niche markets in small-scale activities, often serving the ethnic community, such as restaurants, retail food shops or beauty salons. By reviewing the literature on minority-run businesses in developing countries, this paper (i) gives an overview of important minorities and their economic role in developing countries, (ii) reviews the potential factors behind their relative success, and (iii) provides reflections on what lessons can be learnt from the study of minority-owned businesses and which policy conclusions may be drawn.
\end{abstract}

Acknowledgements: The author gratefully acknowledges funding by the Federal Ministry for Economic Cooperation and Development (BMZ) within the framework of the project "Employment, Empowerment and Living Standards", implemented in cooperation with the German Development Bank (KfW). The author thanks Jann Lay, Stephan Klasen and participants of the doctoral seminar in development economics at the University of Goettingen for helpful comments. The author further thanks Moritz Hoppe for excellent research support. 


\subsection{Introduction}

This paper is motivated, first, by the striking performance differences between minority-run businesses in developed and developing countries documented in the literature, and, second, by the broader lessons about market imperfections that can be learnt from studying minority-run businesses. We understand minority group membership as sharing common cultural characteristics or practices - such as ethnicity, race, language or religion - distinct from the majority population. These community-specific traits are typically visible and known to outsiders (Zhou, 2004).

The overrepresentation of minority groups in the private sector is a global phenomenon. Yet, when comparing the literature on minority businesses in developed and developing countries we observe an interesting puzzle. Minority entrepreneurs in developed countries are typically described as disadvantaged groups, lacking information, access to human and financial resources, mainstream labour and consumer markets, and fluency in the language of the host country. They start businesses characterized by low entry barriers in terms of required capital and educational qualifications, small-scale production, high labour intensity and low value added (Bates, 2011). In contrast, minorities often constitute a market-dominant business community in developing countries. This paper sheds some light on the puzzle by reviewing the literature on the economic role of minority businesses and their success factors in developing countries.

Due to their common cultural heritage and their observable distinction from the majority population minorities often form close-knit social networks. Members of these community networks work together to overcome market imperfections. Although this may improve economic outcomes for members, it may disadvantage possibly more able individuals from other communities (Munshi, 2014). This may result in a misallocation of resources (Banerjee $\&$ Munshi, 2004). The presence and strength of community effects, hence, indicates the degree of market imperfections existent in the environment where the analysed minority-run businesses operate. In other words, minority-owned businesses can be regarded as "reflections of constraints and opportunities operating in broader society"(Bates, 2011, p. 151). Therefore, studying minority-led businesses is relevant and of analytical interest because it illustrates (i) market imperfections causing (ii) constraints to enterprise growth for some groups of entrepreneurs, (iii) a potentially inefficient resource allocation resulting from these imperfections, and (iv) strategies of certain minority groups that allow them to overcome market imperfections. 
The literature on minority-run businesses is extensive. ${ }^{7}$ It can be structured along various dimensions. First, it can be clustered by the nature of the community under investigation. Nationality is by far the most prominent criterion to define minority-led business communities, with an extensive literature on businesses operated by (the descendants of) immigrants. There is as well some evidence on business communities based on (native) ethnic (e.g. clans in sub-Saharan Africa or castes in India) and religious ties.

Second, the literature can be grouped according to the location of the business communities. Minority-run businesses are a global phenomenon and can be found in almost every country around the globe. Yet, most studies are set in developed economies. The single, most researched country are the USA, home to many different immigrant groups. Here, the literature has looked at Hispanic -, African American - and Asian - (in particular Chinese -, Indian - and Korean -) owned businesses. Other developed economies, such as the Netherlands, Canada, France, Germany and the United Kingdom are common host countries for migrant entrepreneurs, too, and frequently subject to research. The focus on these nations reflects the importance of migrant entrepreneurship in the corresponding countries (Kloostermann \& Rath, 2003). There are far less studies on minority-led businesses in developing countries. Here, Indian - and Pakistani-run businesses in East and Southern Africa, Syrian - and Lebanese-led businesses in West Africa and Chinese-operated companies in sub-Saharan Africa and Southeast Asia are the most researched groups. Most publications focus on one location. Crossnational comparisons of minority business communities are rare.

Third, different disciplines have analysed minority-led businesses. Most contributions stem from sociology or entrepreneurship/management studies. The corresponding sociological literature dates back to the 1960s. Starting point was the research question why some communities display a disproportionately high propensity to self-select into self-employment, whereas other minority groups have shunned entrepreneurial activities. By identifying various (community-specific) push and pull factors to entrepreneurship sociologists introduced central concepts in the study of minority-run businesses, such as the importance of social networks. Anthropological publications provide detailed accounts of how certain minority groups established in one location and developed into a business community. A second research topic are the strategies used by minority entrepreneurs to run their business. Entrepreneurship and management studies examine start-up and hiring practices in minority-owned businesses. In

\footnotetext{
${ }^{7}$ A search on Google Scholar for publications written in English with at least one of the expressions "migrant entrepreneurs", "immigrant entrepreneurs", "ethnic entrepreneurs", "migrant entrepreneurship", "ethnic entrepreneurship", "immigrant entrepreneurship", "migrant business", "immigrant business", "ethnic business", "minority entrepreneurship" and "minorityowned business" in the title found 3,246 documents.
} 
comparison, the economic literature on minority-owned businesses is rather recent with some contributions from the 1980s and a renewed interest in the topic at the start of the new millennium. The later studies focus on differential access to resources for various business communities and how this affects economic outcomes.

Related to the disciplines is the methodological approach applied to study minority-run businesses. The majority of the (sociological, anthropological and entrepreneurship) literature consists of case studies of a particular minority group in one city, region, or country. They frequently employ in-depth interviews or observation and are mainly descriptive in nature. Economic studies rather use quantitative data and multivariate analysis. Some recent literature reviews (Aliaga-Isla \& Rialp, 2013; Bates, 2011; Ilhan-Nas et al., 2011; Ma et al., 2013; Nestorowicz, 2012; Zhou, 2004) summarize the theoretical underpinnings and empirical findings in this vast literature. Yet, all literature reviews are limited to studies in developed countries.

This paper aims to close this gap by reviewing the findings on minority-owned businesses in developing countries. What is more, it intends to derive lessons learnt and policy recommendations by illustrating how minority-owned businesses use the prevailing opportunity structure to succeed in business. In order to do so, the first step is to establish that minorityowned businesses are active and operating relatively successfully throughout the developing world. The second step is to review the evidence on factors explaining the performance heterogeneity of minority-and majority-owned businesses in developing countries. Based on these findings, we finally discuss the potential consequences for our understanding of micro and small enterprise development in developing markets. We derive policy recommendations that may contribute to promote the successful business strategies of minority-owned businesses to a wider group of entrepreneurs or to reduce the market imperfections these strategies have revealed.

The literature on minority-run businesses lacks a common definition of the research subject. The concepts of "immigrant", "ethnic" and "minority" as well as "self-employment", "entrepreneurship" and "business" are frequently used but the denotations of these terms differ depending on the specific research topic. In this review, we refer to minority-run businesses as the broadest concept, comprising all of the above-mentioned sub-groups.

The corresponding literature as a whole is too vast for a systematic review. We build on different strands of the literature to serve the three purposes of the paper. First, we scan theoretical contributions and literature reviews on minority-run businesses without any limitation on the location, group or time under investigation. These studies introduce theoretical 
concepts relevant for explaining the differences in performance between majority- and minority-owned businesses. Next, we limit our search to publications of all disciplines on minority business communities in developing countries. There exists plenty of anecdotal and descriptive evidence that allows us to identify important minority business groups in developing countries and to trace their development into entrepreneurial elites. Following, we look at the much smaller literature examining the economic outcomes of minority-owned businesses. We review the factors that potentially cause the differential performance. We present the theoretical considerations and empirical evidence in support of these factors from various disciplines. Yet, we put a special emphasis on economic studies published in peer-reviewed journals or working paper series that analyse inter-group heterogeneity in business outcomes directly or look at group-specific characteristics and/or strategies that influence entrepreneurial performance.

\subsection{Patterns and performance of minority businesses in developing countries}

In the following chapter, we introduce important minority business communities across the developing world. We briefly describe the historical circumstances that led to the formation of these entrepreneurial groups, their size and other characteristics. If available, we provide evidence on the performance of the minority-owned businesses.

\subsubsection{Sub-Saharan Africa}

In sub-Saharan Africa, there are three main immigrant business communities that are frequently subject to studies: (i) Indian- and Pakistani-led businesses in East Africa and South Africa, (ii) Lebanese-owned businesses in West Africa, and (iii) Chinese-operated businesses in various African countries. 
Table 5: Representation of ethnic minorities in firm ownership and the population in selected countries

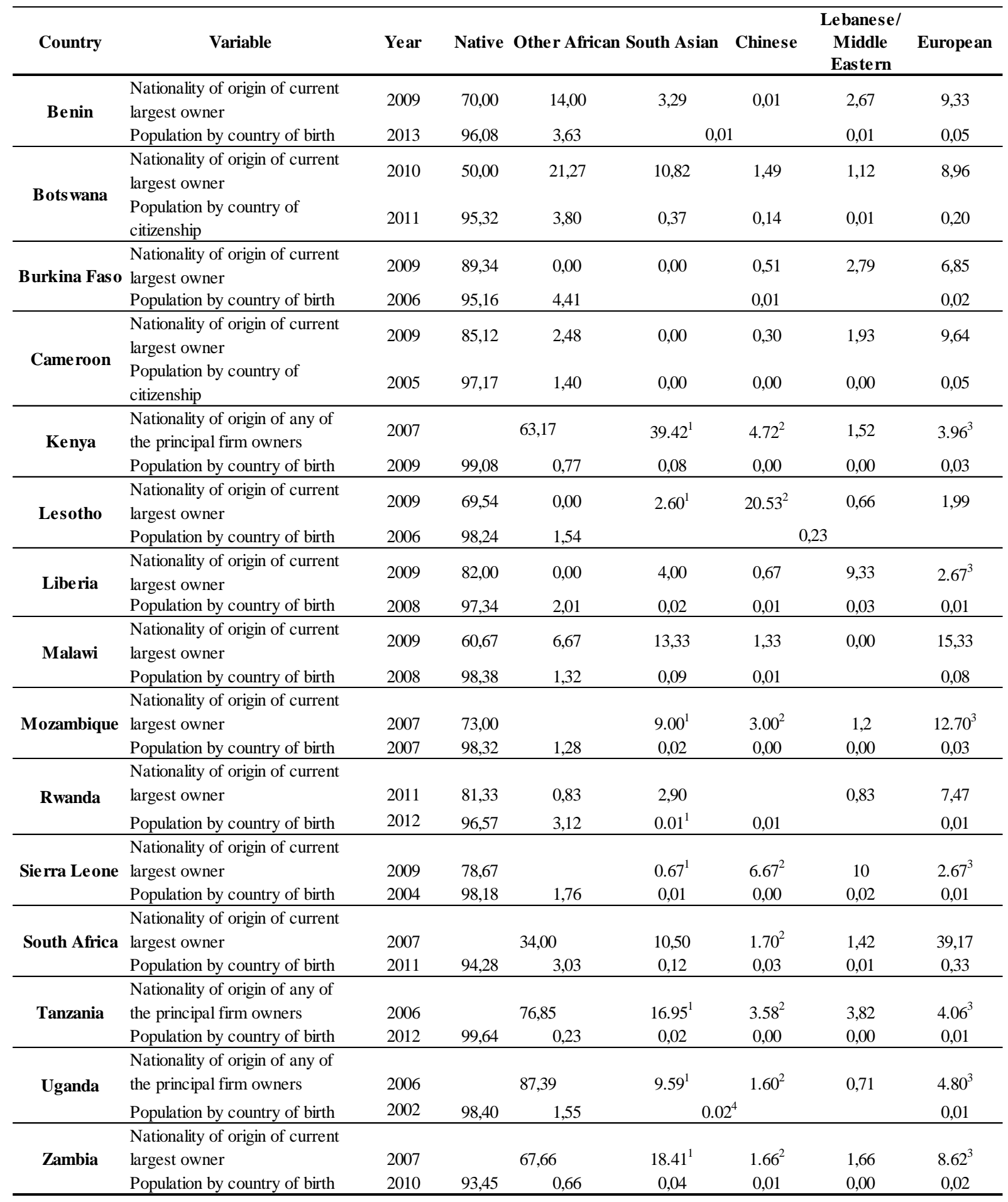

Notes: ${ }^{1}$ Indian, ${ }^{2}$ other Asian, ${ }^{3}$ European or Caucasian, ${ }^{4}$ Asian. Cell is empty if no information on this ethnic group is available. Source: Enterprise Surveys (http://www.enterprisesurveys.org), The World Bank. Minnesota Population Center. Integrated Public Use Microdata Series, International: Version 7.2 [dataset].

Table 5 combines information taken from the World Bank Enterprise Surveys about the nationality of firm owners in a representative sample of private enterprises in various African countries with census data on the ethnic composition of the total population in the respective countries. In all cases presented here, residents of foreign origin constitute a marginal minority 
of the population but are overrepresented in business ownership. In Kenya, for example, residents of Indian descent represent less than 1 per cent of the country's population but own more than one third of all firms. If we split the firm sample by economic activity, we see that minorities particularly engage in retail trade. The World Bank Enterprise Surveys usually include registered firms with five or more employees. Comparable surveys of micro enterprises show that these are more often owned by the native population.

The descendants of European settlers benefit until today from their privileged role established under colonial rule. Thus, Europeans constitute a market-dominant minority in many African countries. Yet, unlike the South Asian or Lebanese minorities in Africa, they controlled politics and administration and were never barred from certain occupations or land ownership. Despite their overrepresentation in the private sector there is hardly any literature looking exclusively on European-owned businesses.

\section{Indian and Pakistani-run businesses in East Africa}

Significant migration of South Asians to East Africa began during the second half of the 19th century. The abolishment of slavery by the British in 1834 created an enormous demand for cheap labour. Over 30,000 Indians, most of them Sikhs from the Punjab, arrived in East Africa on three-year contracts to work as indentured labourers for various public works, most importantly the Kenya-Uganda Railway. After their contract ended, about 20 per cent of them decided to stay in East Africa and to establish small retail shops in the opened-up interior of the countries (Godfrey, 2007). These Indian shopkeepers were the first to introduce imported consumer goods to the rural population throughout East Africa (Ghai \& Ghai, 1965). This allowed them to exploit formerly untapped market potential. They were followed by large numbers of 'free' emigrants, mostly from the Indian state of Gujarat (Cable, 1969; High Level Committee on the Indian Diaspora, 2001). These subsequent migrants were relatively prosperous, experienced businessmen in search of new opportunities.

The colonial policy of divide and rule separated society along racial lines, with the Asian community serving as intermediate class in the system - below the Europeans but above the African population. On the one hand, the political system limited the employment choices of Asian migrants due to restrictions on land holding, salary discrimination and obstacles to entry and promotion in civil service (Cable, 1969). On the other hand, the British administration opened up new opportunities by installing Indian traders as intermediaries to develop a commodity trading system in the rural areas of East Africa. This partly explains the concentration of Indian-run businesses in retail and wholesale trade. 
At the time of independence, about 360,000 Indians and Pakistani lived in Kenya, Uganda and Tanzania (Ghai \& Ghai, 1965). After independence, the new governments in East Africa pursued a policy of Africanisation that resulted in further social and economic restrictions for the Asian community and consequently in the migration of many Indians and Pakistani to the United Kingdom or their home countries. In Uganda, this policy culminated in the expulsion of all Asians by General Idi Amin in 1972. Today it is estimated that there are about 8,000-13,000 people of Indian or Pakistani origin living in Uganda (Godfrey, 2007). The majority of them came to East Africa rather recently in the 1980s or 90s. Whereas the first South Asian migrant entrepreneurs specialized in commerce, today Indian-owned businesses are also commonly found in manufacture (especially textile manufacturing and printing) and financial services.

\section{Indians and Europeans in Southern Africa}

Indians first arrived in South Africa in 1653 where Dutch merchants sold them as slaves to early Dutch settlers (High Level Committee on the Indian Diaspora, 2001). Large numbers of Indian migrant workers were brought to South Africa in 1860 by white farmers from Natal to work on their sugarcane and sisal plantations. By 1969, Gujarati traders started coming to South Africa in search of business opportunities (Bhowan \& Tewari, 1997). They mainly set up retail stores but also established manufacturing businesses, especially in the clothing, footwear and furniture industry. Indian manufacturers are largely concentrated in Kwa-Zulu Natal and Johannesburg in Gauteng province.

After colonial rule, the European settlers maintained their economic preponderance in Southern Africa. British settlers were the first European entrepreneurs during the 18th century. In Zimbabwe, Europeans still own about $40 \%$ of the country's large firms.

Ramachandran and Shah (1999) compare growth rates of indigenously-owned African firms with those of businesses run by Asian or European entrepreneurs in Kenya, Zimbabwe, and Tanzania. They find that after controlling for firm and owner characteristics as well as sector and country differences, firms owned by Asians or Europeans start out larger and grow significantly faster in terms of employment than African-run businesses. Using the same data, Biggs and Shah (2006) show that firms owned by European or Asian entrepreneurs start out at twice the size of indigenous African businesses and grow 13 per cent and 9 per cent faster, respectively. In addition, Asian-owned firms exhibit a 37 per cent higher productivity (measured as value added) than indigenous firms. 


\section{Lebanese in West Africa}

The Lebanese first immigrated to West Africa between 1898 and 1914, in a time when the Ottoman Empire experienced economic decline coupled with religious and political persecution. Large Lebanese communities are found in Côte d'Ivoire, Ghana, Sierra Leone, Mali, Senegal and Guinea. West Africa was chosen as a migration destination because immigration requirements were less strict than in the United States or other developed countries. Furthermore, many emigrants lacked the funds to continue the journey to their desired destinations in North or South America and found themselves stranded at intermediate stops at the Western coast of Africa (Goodwin, 2006). A second immigration wave started in 1975 following the Lebanese civil war and subsequent Israeli invasion.

The Lebanese community in Western Africa is very cohesive. They have come from the same communities in southern Lebanon and have, in turn, settled in particular locations in their host countries (Bierwirth, 1999). Once the first emigrants became established in West Africa, they encouraged their families and kinship to follow (chain migration). Most Lebanese-run businesses are active in retail or wholesale trade. In fact, it is believed that the Lebanese conduct two-thirds or more of the total wholesale trade in Côte d'Ivoire (ibid.) and own 60 per cent of all small and medium-sized companies in Senegal (Goodwin, 2006). Lebanese merchants have also become involved in the collection, bulking and transport of cash crops. More established Lebanese merchants reinvested their capital into the manufacturing sector. By 1990, LebaneseIvorian entrepreneurs owned more than $50 \%$ of the national manufacturing companies (Bierwirth, 1999).

Indian entrepreneurs in East and Southern Africa and Lebanese entrepreneurs in West Africa share certain similarities. Colonial rule determined the status of these migrant minority groups as an intermediate class in the host society. This social status enabled them to take up an intermediary merchant role between the native population and the colonial power (Goodwin, 2006). Whereas the colonial settlers usually resided in the coastal towns, Indians and Lebanese penetrated the interior and established themselves as indispensable middlemen, bringing goods produced or imported in the coastal towns to African consumers in the interior. Their economic success facilitated chain migration: existent co-ethnic migrant communities facilitated the arrival of further migrants in search of business opportunities. Furthermore, both communities remained rather unassimilated in their host countries. This fostered the formation of strong social networks both, within the diaspora and internationally linking the migrant community with their country of origin. 


\section{Chinese in Africa}

Chinese-owned businesses are widespread across sub-Saharan Africa. In 2009, there were approximately one million Chinese residing in Africa (Gadzala, 2009), the majority of whom can be found in Southern and Western Africa (Haugen \& Carling, 2005; Kernen \& Vulliet, 2009). Migration from China to Africa has existed for over 500 years, but most Chinese have emigrated rather recently, following reforms in China after 1978, especially emigration liberalization in 1985 (Dobler, 2009). Migrants mostly came from Southern China (predominantly from Shanghai, Zhejiang and Fujian Province) although this pattern is vanishing as internal migration in China is freed up (Mohan \& Kale, 2007). They often form sub-communities in their host countries with strong cleavage between them (Harrison et al., 2012; Khan Mohammad, 2014). They primarily reside in the urban centres of sub-Saharan Africa and run retail or wholesale shops, restaurants or traditional Chinese clinics. In contrast to the Indian and Lebanese communities described earlier, Chinese traders were not brought to Africa by historical circumstances - such as the indenture system under colonial rule - but migrated in order to seize economic opportunities in the host country. In Africa they have found a high demand for goods that are cheaper than those already on the market, although inferior in quality or style, and (at least initially) few barriers to market entry in the form of business regulations and requirements for capital and knowledge (Haugen \& Carling, 2005).

\section{Domestic ethnic minorities}

Apart from the market dominance of the migrant minorities highlighted above, there is significant heterogeneity in business ownership and performance among African ethnic groups as well. Mengistae (2001) looks at manufacturing businesses in Addis Ababa, Ethiopia and finds that the rate of business ownership as well as business size is far greater for one ethnic minority group, the Gurage, than for any other indigenous community. In Cameroon, the Bamiléké dominate petty trading, retail and transportation in urban centres. They have established a nationwide network of local lending associations (tontines) (Chua, 2003). The Serahule ethnic group makes up only about 9 per cent of the Gambian population but is overrepresented in the trade business (Gajigo \& Foltz, 2010). The Tutsi dominate commerce in Rwanda and Burundi, where they comprise 14 per cent of the population yet hold approximately 70 per cent of the country's wealth (Carney, 2007). Within Nigeria, Ibo subcommunities dominate key economic sectors (Chua, 2003). While the above-mentioned ethnic minorities mainly operate in their country of origin, other entrepreneurial ethnicities expanded to neighbouring countries. Among them are the manding-jula who developed trading networks 
in Côte d'Ivoire, The Gambia and Niger, and the Hausa and Igbo merchant communities of Nigeria.

Gajigo and Foltz (2010) and Mengistae (2001) both find significant positive community effects in firm performance for indigenous ethnic minority groups. Medium-sized manufacturing firms owned by an indigenous minority ethnic group in Ethiopia, the Gurage, exhibit higher growth rates in terms of employment than businesses run by members of any other ethnic group. This is despite Gurage business owners being the least educated ethnic group in the sample. Similarly, the Serahule, an ethnic minority group based in The Gambia, earn on average higher business profits and exhibit lower marginal returns to capital at a given investment level than non-Serahule owned firms, thus potentially hinting at lower credit constraints.

\subsubsection{Southeast Asia}

\section{Chinese in Southeast Asia}

The best-documented entrepreneurial migrant community in developing countries is the overseas Chinese in Southeast Asia. Large-scale Chinese migration to Southeast Asia started with the opening of China after its defeat in the Opium War in 1842 (Yen, 2013). Many Chinese were recruited as plantation and mine workers by the British in Malaya and the Dutch in the East Indies (Wu, 1983). Later, they started to operate their own businesses, ranging from trade to manufacturing. They acted as intermediaries between the European colonial power and the local population. Throughout Southeast Asia, the Chinese prospered under colonial laissez-faire policies. Favourable economic conditions brought a rapid influx of Chinese immigrants until the middle of the 20th century. Privatization and other market reforms introduced in the 1980s and 1990s magnified the economic dominance of the Chinese minority (Chua, 2003).

Major Chinese populations can be found in Malaysia, Indonesia, Singapore, Thailand and (to a smaller degree) in the Philippines (Crawford, 2000). The following table displays some details regarding their presence. 
Table 6: Characteristics of overseas Chinese in Southeast Asia

\begin{tabular}{|c|c|c|c|c|}
\hline & Indonesia & Malaysia & Philippines & Thailand \\
\hline $\begin{array}{l}\text { Presence of } \\
\text { Chinese }\end{array}$ & $\begin{array}{l}3.8 \mathrm{~m} . \text { ( } \sim 3 \% \text { of } \\
\text { total } \\
\text { population) }\end{array}$ & $\begin{array}{l}5.6 \mathrm{~m} .(\sim 30 \% \text { of } \\
\text { total population) }\end{array}$ & $\begin{array}{l}1.4 \mathrm{~m} .(\sim 1.5 \% \text { of } \\
\text { total population) }\end{array}$ & $\begin{array}{l}6.3 \mathrm{~m} .(\sim 12 \% \text { of } \\
\text { total population) }\end{array}$ \\
\hline Specialization & $\begin{array}{l}\text { Active in } \\
\text { virtually all } \\
\text { sectors }\end{array}$ & $\begin{array}{l}\text { Significant } \\
\text { presence in } \\
\text { property and } \\
\text { financial sector }\end{array}$ & $\begin{array}{l}\text { Significant } \\
\text { presence in } \\
\text { manufacturing, } \\
\text { commerce and } \\
\text { finance }\end{array}$ & $\begin{array}{l}\text { Significant } \\
\text { presence in } \\
\text { commerce and } \\
\text { industries }\end{array}$ \\
\hline $\begin{array}{l}\text { Policy in host } \\
\text { country }\end{array}$ & $\begin{array}{l}\text { Ethnic-biased } \\
\text { pribumi policy }\end{array}$ & $\begin{array}{l}\text { Ethnic-biased } \\
\text { bumiputra policy }\end{array}$ & $\begin{array}{l}\text { Ethnic-biased } \\
\text { industrial policy }\end{array}$ & $\begin{array}{l}\text { Ethnic } \\
\text { assimilation } \\
\text { policy }\end{array}$ \\
\hline $\begin{array}{l}\text { Ethnic Chinese } \\
\text { ownership of } \\
\text { private-sector } \\
\text { assets }\end{array}$ & $70 \%$ & $65 \%$ & $40 \%$ & $90 \%$ \\
\hline
\end{tabular}

Source: Carney, 2007; Menkhoff and Solvay, 2012; Pann, 1998; Yeung 1999

In all these countries, entrepreneurs of Chinese descent dominate certain sectors of the economy. In Indonesia, where they only account for about 3 per cent of the total population, they control 70 per cent of private capital and 66 of the country's top 300 conglomerates (Menkhoff \& Solvay, 2012). Estimates of Chinese economic control in the Philippines range between 50 per cent and 65 per cent (Chua, 2003). Vietnam's 3 per cent Chinese minority cluster in Ho Chi Minh City controls about 50 per cent of that city's market activity and overwhelmingly dominate light industry, trade, retail and private banking (ibid.). A survey of Thailand's 70 most powerful business groups in the 1980s revealed that Thai Chinese owned all but three of them (ibid.).

Nearly all overseas Chinese came from the Southeastern provinces of Guangdong and Fujian. They kept strong cultural bounds to China and Confucian ethics, even after centuries of family settlement elsewhere (Yen, 2013). The common cultural background and the hostile environment in the host country fostered the formation of strong sub-ethnic relationships, defined by clan affiliation or native place (also called 'the bamboo network'). Whereas the Chinese in Malaysia and Indonesia remained distinct cultural groups in society, many assimilated into Thai culture where political and social discrimination were largely absent (Freedman, 1979). The literature attributes the general economic success of the Chinese abroad to their prior experience and sophistication in the handling of money (Freedman, 1959). They came from a highly commercially developed economy, experienced in dealing with trade and agricultural credits, deposit banking and remittances (Wu, 1983). 


\subsubsection{Summary}

The above presented minority communities in sub-Saharan Africa and Southeast Asia are subject of the relevant literature. Certainly, other groups - such as the Marwaris in India, Indian migrants in Southeast Asia or Lebanese settlers in Latin America - are overrepresented in business as well. Yet, hardly any empirical accounts on their formation as a dominant business minority nor on the economic performances of these businesses can be found.

The above overview shows that minorities have established successful business communities in many parts of the developing world. Native as well as migrant minority groups tend to be overrepresented in middle- and large-scale businesses. Migrant business communities have often formed through chain migration: successive waves of migration built on earlier trajectories. The concentration of certain migrant groups in particular market niches and their economic success inspired further migration waves and facilitated the entry and economic performance of late arrivals. In most countries, they formed distinct communities and remained unassimilated from the host culture.

Migrant groups seem to evolve particularly often into successful business communities. Historical events (most notably colonial policies) have given these groups initial advantages in entrepreneurship that were reinforced over time. In many countries, this economic imbalance provoked resentment among the majority population and resulted in affirmative action or more drastic political measures to reduce the ethnic concentration in business.

\subsection{What factors explain these differences in performance?}

In the following chapter, we discuss factors identified in the literature that are deemed conducive to the economic performance of minority businesses. First, we focus on individual and group characteristics that may give (certain) minorities an advantage in doing business. Second, as already indicated in the previous chapter, we show how historical events and policies may push minorities into the private sector and may facilitate their business operation. Thereafter, we focus on institutions that may reinforce the position of minorities as successful business communities. We show how the absence of functioning formal institutions (e.g. courts) and ill-functioning markets in developing countries give rise to informal market institutions that promote ethnic concentration in business. One key institution is this context are (ethnic) business networks that disadvantage outsiders in business through statistical discrimination and restricted information sharing. A second key institution is relational contracting in which contracts are enforced through reputation without reference to formal institutions. We show 
how this form of contracting again favours minority business communities and grants them access to resources unavailable to members outside the community. Finally, we look at policies that aimed to dismantle the dominance of certain minority groups in business.

\subsubsection{Culture, individual characteristics and selective migration}

Early work has focused on cultural traits in order to explain heterogeneous rates of selfemployment and economic success between different ethnic groups. This line of thought assumes that some ethnic and migrant groups are equipped with culturally determined features that foster successful business operation, such as a dedication to hard work, economical living, acceptance of risk, and a general orientation towards self-employment (Masurel et al., 2004). The theory of middleman minorities draws heavily on cultural factors to explain the development and persistence of minority business communities. Middleman minorities are nonassimilating migrant minorities operating their businesses around a diasporan structure (Light, 2007). Traditional middleman minority perspectives assume that the minority entrepreneurs arrive as sojourners thus, specializing in businesses where investments can quickly be liquidated, such as trade (Bonacich, 1973). With the objective to return to the homeland in mind, they are willing to work excessively long hours, emphasize savings over consumption, and retain close ties to their mother country. The Jews in Europe, the Chinese in Southeast Asia and the Indians in East Africa are examples of historical and contemporary middleman minorities.

Sociological and anthropological accounts often attach the above-cited characteristics to migrant minority communities in developing countries. For example, Ghai and Ghai (1965) describe the early Asian settlers in East Africa as imbued with quasi-Protestant ethics, a strong commercial sense, the capacity to work long hours, low propensity to consume, and a passion for the accumulation of capital. Similarly, the literature depicts Chinese immigrants as hardworking, thrifty, risk-taking and self-reliant (Mackie, 1992). Jenssen and Kristiansen (2004) state that Asians are less bound to their places of birth, and their geographically dispersed network of family and clan members facilitates communication and mobility, which is of importance for innovations and business success. Yet, the role of cultural factors in explaining the incidence and performance of minority businesses can only be limited. Culture is not a static concept, irrespective of time and place. Many migrant entrepreneurs, for instance, belong to the second or third generation and might therefore display very different cultural traits than their ancestors.

Migrant entrepreneurs are a self-selected group and, as a result, may be more able and more motivated in business than the native average entrepreneur (Borjas, 1987). There is a 
positive selection bias in the sense that many migrant entrepreneurs chose to migrate and run a business in the host country because they are confident about the success of their endeavour. This may be because they have a superior initial endowment of capital, market and technical knowledge, business experience and acquired traditions (Kilby, 1983). One factor explaining the performance difference between migrant entrepreneurs in developed and in developing countries may thus be their relative resource endowment. Whereas migrants to developing countries often possess relative more resources than the local population in the host country, migrant entrepreneurs in developed countries often come from poorer economies and have relatively less capital and education. By definition, migrant entrepreneurs are less risk-averse and more mobile than the average person is. Geographical mobility can be regarded as a valuable resource in business development as it brings the entrepreneur in contact with new ideas, networks and business processes (Kristiansen, 2004). Moreover, migrant entrepreneurs often possess skills and knowledge (e.g. bilingualism, international contacts) that can reduce transaction costs and give them a competitive advantage in international trade.

Freedman (1959) has argued that Chinese emigrants came from societies in Southeast China in which experience in the handling of money, debts and credit was more widely distributed than in the places they emigrated to. Hence, even the unskilled had an initial advantage in commercial transactions over the people amongst whom they lived. Similarly, Asian immigrants in East Africa came particularly from communities that are strongly overrepresented in business in their home countries as well (Kristiansen \& Ryen, 2002). Lin (2014) describes the motivation of Chinese migration to Africa as a "small pond migration strategy": migrants move from a more developed to a less developed country or region to take advantage of the characteristics at the receiving place, which effectively increase their existing social, economic, and human capital.

Several empirical studies highlight the higher human capital of migrant entrepreneurs compared to their local competitors in sub-Saharan Africa (Biggs \& Shah, 2006; Ramachandran \& Shah, 1999). Yet, the significant and robust correlation between ethnicity and various measures of firm performance found in many empirical studies persists even after controlling for owner and firm characteristics. Mengistae (2001) therefore concludes that at least part of the better performance of minority entrepreneurs is due to some unmeasured ability such as drive or energy. 


\subsubsection{Settlement patterns and policies}

Minority or migrant communities are often subject to residential and occupational restrictions that force them into certain neighbourhoods and activities, thereby facilitating the circulation of information and raising the cost of exclusion from the group (Fafchamps, 2001b) . Group size and geographical dispersion negatively influence the monitoring and sanctioning capacity of the community.

Patterns of chain migration and discrimination lead to the build-up of ethnic residential areas, presenting ethnic entrepreneurs with an ethnic, protected consumer market. Ethnic entrepreneurs best know the special tastes and preferences of their community and thus may have an advantage over native competitors in catering to those needs (Aldrich $\&$ Waldinger, 1990). Ethnic consumer tastes provide a protected market position, in part because members of the community may have a cultural preference for dealing with co-ethnics, and in part, because the costs of learning the specific wants and tastes of the minority groups discourage native firms from doing so. Common preferences among a minority group also establish niche markets for specific cultural goods (e.g. food and music). However, if ethnic businesses remain limited to the ethnic market their growth potential is confined to the quantitatively small minority population and ethnic-specific goods and services.

An extension to the ethnic, protected consumer market is the ethnic enclave. Ethnic enclave businesses are defined as (i) spatially clustered businesses owned by members of a specific ethnic group, and (ii) firms located in a community where residents frequently share the ethnic identity of the business owner (Bates, 2011). In contrast to the local ethnic consumer market, the business clustering entails a high level of diversity, including not just niches shunned by natives but also a wide variety of economic activities common in the general economy (Zhou, 2004). Furthermore, the enclave's industries are also linked to the general, non-ethnic market. Even though, the ethnic enclave is a much-discussed concept in the literature on minority businesses it remains unclear how the spatial distribution of minority businesses affects their economic performance.

\subsubsection{Social capital and networks}

Fafchamps (2004) argues that the distinct patterns of ethnic concentration in business can to a large degree be explained by a restricted entry process in business networks and by network externalities. Since network externalities bestow comparative advantages in business on network members, minority communities earn rents and become dominant in particular segments of the economy. 
Members of a minority community typically share the same values, traditions and cultural beliefs. This facilitates the development of trust and social relationships within a community. Phenotypical or cultural characteristics that set the community apart from the majority population can give rise to prejudice and discrimination outside the community. This in turn fosters sentiments of in-group solidarity among its members (Portes \& Sensenbrenner, 1993). Exit options, such as the return of migrant entrepreneurs to their home countries may not be readily available. Therefore, the importance of the community is reinforced.

Results of micro-economic game experiments show that people tend to have more trust in people of the same race or nationality than in other people (Buchan et al., 2002; Glaeser et al., 2000). Survey data of manufacturing enterprises in Kenya, Tanzania, Zambia and Zimbabwe show that trust forms the basis for market exchange in these contexts. Interviewed firms generally deal with a single supplier of a particular input on a regular basis (even when they have a choice among different sources of supply), and the average length of the relationship exceeds seven years (Bigsten et al., 2003). Minority entrepreneurs show a low propensity to use mainstream business support agencies, often relying instead on self-help and informal sources of assistance through their social network (Carter \& Jones-Evans, 2009; Ram \& Smallbone, 2002).

Social capital is accrued through social networks (Lin, 1999). Whereas the structure of the social network determines the kind of resources a person may be able to access, social capital allows the transaction to take place. Small, homogenous and cohesive networks may be more suited to reduce uncertainty and overcome credit constraints, whereas numerous and diverse contacts may transmit better information about technologies and markets (Barr, 2002). Barr (2000) demonstrates that Ghanaian manufacturers with large and diverse contacts outperform less connected firms, suggesting that these networks facilitate knowledge flows between enterprises. Looking at the structure of entrepreneurial social networks, Rooks et al. (2009) show that a strong overlap of the personal and business network hampers innovative performance of urban entrepreneurs in Uganda. Investing time in cultivating a redundant contact at first increases innovation by solving information and cooperation problems. However, if there are many connections between the entrepreneur's relations information will be less diverse and redistributive kinship pressure may play a more important role, draining entrepreneurial resources. McCormick (1995) compares the networks of Asian and Kenyan garment producers in Nairobi. Whereas Asian networks appear very conducive to business growth - comprising textile wholesalers, shop owners, bankers, other garment producers, sewing machine vendors and a wide range of middle-income consumers - the networks of 
African entrepreneurs are more limited to their family, often based in rural areas. Ali and Peerlings (2011) find that maintaining ethnic ties in trade relationships reduces the business profits of small-scale producers in the handloom sector in Ethiopia. The negative effect of having limited flows of new business-related ideas in closed social networks appears to offset the benefits of ethnic ties. Whereas migrant entrepreneurs often stay in contact with their kinship and social ties back home, indigenous African business networks are typically not linked to other groups outside the region that could provide important models, ideas and resources.

The social network may also act as an impediment to entrepreneurial dynamics. This may be the case when less successful members of the kin confront economically successful entrepreneurs with sharing obligations. These obligations may require entrepreneurs to transfer money, employ kin in their enterprise or host relatives in their home (Hoff \& Sen, 2006; Platteau, 2000). In principle, these transfers may occur voluntarily and even foster entrepreneurial activities through providing access to supportive network services. However, if insurance or societal pressure for redistribution are the main motivating factors these networks might hinder capital accumulation and put brakes on entrepreneurial activity. Forced solidarity can increase the operating costs of firm owners and adversely affect their incentives to pursue and develop their business. Platteau (2000) presents a game-theoretical analysis showing that sharing norms can block economic growth in conditions where actors have differential capacities for material advance and where economic individualism entails costs by eroding mutual insurance potential and encouraging positional externalities.

Forced solidarity is usually exercised by family or kinship. The main difference between family and kinship ties, on the one hand, and the social network as a generic set of individuals who interact, on the other, is that family and kinship ties can be seen as largely exogenous and can be changed only at high psychological costs (La Ferrara, 2010). Migration and religious conversion are two routes that an entrepreneurial individual can take to escape the constraints on private wealth accumulation posed by sharing norms in traditional societies. Being strangers, migrant entrepreneurs stand outside of the complex web of social obligations that surround economic transactions in their host country. Similarly, religious conversion may serve to shun involvement in customary kinship networks and may partially explain the relative entrepreneurial success of religious minorities. Jehovah's Witnesses, for example, are disproportionally represented in the commercial farmer and shopkeeper business in Zambia (Platteau, 2000). In contrast, entrepreneurial resources, such as information, capital and labour are usually mobilized within the wider social network. Dynamic entrepreneurs may also receive 
demands from members of their wider network but here deviant behaviour (such as default on a loan) is less socially accepted and easier to sanction.

The aspect of forced solidarity has not been adequately taken into account in many empirical studies trying to establish the net effect of social capital on business success. To date, there is little empirical backup for the existence of negative effects of social networks. Some related evidence, however, indicates that the composition and structure of the household matters for capital accumulation, e.g. that larger polygamous households find it more difficult to save and accumulate (Morrisson, 2006). Duflo et al. (2011) put forward a similar argument, when showing that impatient Kenyan farmers forgo highly profitable investments in fertilizer. The authors argue that the impatience is partly rooted in the difficulty of protecting savings from consumption demands. Di Falco and Bulte (2011) present evidence that kinship size is associated with higher budget shares for non-sharable goods. Baland et al. (2011) analyse borrowing behaviour in Cameroun and find that some people take up credit even without liquidity constraints to signal to their kin that they are unable to provide financial assistance. Anderson and Baland (2002) provide some evidence that women in Kenya participate in Rotating Saving and Credit Associations (ROSCAs) to protect savings against claims by their husbands. Applying a field and real effort experiment in Burkina Faso, Hadnes et al. (2013) show that implicit and explicit solidarity obligations as well as the expectation of future claims for financial support lead to a significant reduction in the productivity of tailors.

The opportunities or advantages of some entrepreneurs pose a constraint to others. The benefits of networks, for example, are confined to its members, and they will often be the larger the more imperfect the environment. Even though the network and social capital literature has focused on case studies on how specific groups benefit from preferential access, more recently the other side of this coin - exclusion for other groups - has been addressed more systematically (Staveren \& Knorringa, 2007; Turner, 2007).

\subsubsection{Overcoming institutional failure (contract enforcement)}

Contract enforcement enables agents to enter into complex trade relationships, involving various forms of forward contracting (e.g. order, credit, and warranty). However, contracts will only be respected when economic agents are able and willing to comply with their obligations. Willingness to comply is assured only if an enforcement mechanism exists that penalizes breach of contract. There are three types of enforcement mechanisms: (i) enforcement through moral values, i.e. feeling guilt or shame for failing to respect business promises; (ii) enforcement through legitimate or illegitimate coercion, e.g. court action or harassment; and (iii) 
enforcement through repeated interaction (Fafchamps, 1996). The use of coercion to enforce contracts is costly. Small transactions usually do not justify the legal costs of court action. This is even more so in developing countries where the legal system is often characterized by high costs, lengthy time periods for issue resolution and unequal access to justice (Court et al., 2003). Whenever the threat of coercion is not believable, it fails to induce contract compliance. In the case of repeated interaction, the punishment lies in the suspension of future trade with the creditor and the potential loss of future transactions with other trading partners after the debtor's reputation is damaged. If information about contract breaches circulates freely among economic agents, breach can be deterred by excluding cheaters from future trade (Greif, 1993). However, the effectiveness of collective sanctions through which enforceable trust is built depends on the group's ability to monitor the behaviour of its members and its capacity to publicize the identity of deviants. It seems likely that the returns to social capital eventually decrease with group size because the costs of information circulation increase exponentially with group size. Furthermore, larger groups may not be able to impose social sanctions onto deviant members because they lack the capacity to punish those who refuse to ostracize past cheaters (Fafchamps, 2001a). This may explain why minorities have an advantage over economic agents belonging to the majority population.

Greif (1993) analyses historical documents to show how 11th-century Mediterranean traders formed a coalition to overcome commitment problems between them and their overseas agents. In this coalition, a reputation mechanism governed agency relations since merchants conditioned future employment on past conduct, practiced community punishment, and boycotted agents who were considered cheaters until they compensated the deceived. Agents even forewent current gain to sustain their good standing in the merchants' group. In more present-day economic transactions, empirical evidence of collective punishments for opportunistic breach of contract is scarce (Fafchamps, 2001b).

\subsubsection{Access to resources}

Minority entrepreneurs are able to mobilize resources through their social network, which may not be possible for every member of the majority population. This way they circumvent market imperfections and reduce transaction costs.

\section{Access to information and contacts}

Information primarily circulates among interpersonal networks. In such an environment, individuals with better networks collect more accurate information, which enables them to seek 
out profitable market opportunities and to better screen prospective employees and credit recipients (Fafchamps, 2000). One role of information sharing that seems particularly relevant in markets with inadequate legal institutions and few formal market regulations is reputation. In uncertain and risky environments, risk-averse entrepreneurs may be hesitant to extend their business contacts out of the reach of personal trust, thus foregoing profitable business opportunities (Kristiansen \& Ryen, 2002). Sharing information about past contractual history enables good agents to identify each other faster and to do business outside the personal trustbased network. Reputation is a form of social collateral that guarantees contract performance without prior acquaintance. Economic agents who belong to an information-sharing group rely on each other's reputation when initiating business transactions. Trust and reputation also make it easier for agents to renegotiate their contractual obligations when problems arise, thereby providing needed flexibility when dealing with external shocks. Thus, firms within an information-sharing network are at an advantage compared to firms that are outside the network because they can reach further, expand faster, and spread risk more easily (Fafchamps, 1996).

\section{Access to labour}

Social networks can help to economize on search and screening costs for employees. Montgomery (1991) shows that firms use employee referral to identify and hire high quality workers. He incorporates social ties in an adverse selection model of the labour market and shows that in equilibrium workers who are well connected (i.e. possessing social ties to those in high-paying jobs) receive higher wages and firms hiring through referral earn higher profits. Assuming free firm entry and asymmetric information on workers' ability, firms hiring through the market earn zero expected profit. However, given imperfect competition for referred workers, firms hiring through referral earn a positive expected future profit.

In addition, referred workers may be of higher quality. First, the human resource literature states that workers tend to refer persons who are similar to themselves (Rees, 1966). Employers will thus solicit referrals only from high-ability employees. Second, it seems plausible that referred job applicants receive more information about the position from their contacts and therefore have superior knowledge of their match quality. In this situation, selfselection will occur because job seekers who expect to be a poor match will not bother to apply (Wanous, 1980). Finally, an employee is likely to refer only well-qualified applicants since his reputation is at stake (Rees, 1966). The prediction that workers hired through referral are of higher average quality has received some empirical support in the human resources literature (Breaugh, 1981; Hill, 1970; Schwab, 1982). Yet, Egbert et al. (2011) find no significant 
differences in the recruitment strategies of small and medium firms owned by native - and Asian entrepreneurs in Tanzania. The majority of firm owners relies on informal recruitment mechanisms, comprising the re-recruitment of former employees, walk-ins and referral.

Social ties may not only be beneficial for finding and screening new employees but also for their supervision. The ethnic network can be seen as a trust-creating device that makes it possible to economize on the transaction costs, which accompany the monitoring of employees' efforts. The informal ties are used as means of managerial discipline that mitigate the moral hazard problems inherent to principal-agent relationships. Co-ethnic employees may be hardworking and compliant (thus reducing monitoring costs) due to a feeling of obligation towards and strong social ties with the employer (Waldinger et al., 1990).

Furthermore, employees may consider working in a co-ethnic enterprise as a steppingstone to becoming an independent entrepreneur. Many minority entrepreneurs acquired the skills necessary for operating their business during prior employment in co-ethnic firms. The reciprocity implicit in network hiring reduces the likelihood that workers will quit in the short run and, therefore, enhances an employer's willingness to engage in training (ibid.).

At least in firms catering to the local ethnic market, co-ethnic employees are more productive in co-ethnic firms than employees with a different cultural background because of culture-specific skills. However, in the long run, co-ethnic employment might form an obstacle to the social and economic emancipation of ethnic minority groups. It generates disincentives for individual group members to acquire general skills and may hinder further growth of the firm. The employer might feel a moral obligation, resulting from the social network, to exert positive discrimination against co-ethnic personnel irrespective of their productivity. There is no empirical literature comparing the productivity of co-ethnic and non-co-ethnic employees.

\section{Access to credit}

Similar mechanisms to those described above are at work in the credit market and can explain why social networks may facilitate access to informal credit. First, the problem of asymmetric information is reduced, as network members usually know each other directly or through mutual contacts. Therefore, moneylenders can better assess the creditworthiness of their potential clients and adjust the interest rate accordingly. Second, the moneylender can obtain information about the use of the credit as well as the credit recipient's effort through his social network and so reduce the scope for opportunistic behaviour. The debtor also has a strong interest in repayment as in the case of default he might be sanctioned by the community and may not be able to obtain another loan from the creditor or a different source within the network. 
This threat is particularly relevant if the debtor is excluded from formal financial institutions and thus has no other opportunity to obtain finance.

Another explanation for preferential credit access is based on discrimination against trading partners of different backgrounds. To economize on screening costs, firms may simply infer each other's type from easily observable characteristics like ethnicity. Small differences in the average type across a population with different observable characteristics can then lead to statistical discrimination against outsiders (Fafchamps, 1996). Moreover, Platteau (2000) argues that firms may exhibit "preferential honesty", whereby they are less likely to renege on within-community contracts. If this is the case, moneylenders will be more inclined to provide credit within their community. In the long run, these mechanisms can support ethnic concentration in certain industry sectors. Obtaining credit through the social network lowers the cost of capital and may promote higher investment levels among firms with strong social ties.

The problem of asymmetric information in principal-agent relationships is aggravated in developing countries because there are less institutions that collect and provide information about bad players (such as credit reference bureaus), signal uniform product quality (quality standards and controls) or qualifications (credible certification establishments in school, etc.). Consequently, the transaction costs related to the screening of prospective employees or credit recipients are higher.

Bräutigam (2003) notes that indigenous business networks in sub-Saharan Africa are less likely to provide access to credit, information and best-practice examples than immigrant European or Asian networks. In Nigeria's northern plastics industry, for example, up to 60 and 70 per cent of Lebanese and Chinese factory owners received their start-up capital from their extended families and networks. In contrast, 71 per cent of indigenous Hausa entrepreneurs financed their investments through personal savings (Zakaria, 1999).

According to the empirical evidence, ethnicity plays no role in determining access to formal credit but significantly influences access to informal finance, especially supplier credit. Asian and European-owned firms are more likely to receive supplier credit than their African competitors are. This seems to be due to extensive ethnicity-based information flows amongst minority firms that enable suppliers to ameliorate problems of incomplete information and to use reputation as an enforcement mechanism (Biggs et al., 2002; Fafchamps, 2000). However, Fisman (2003) argues that only about 15 per cent of the differential credit access between Asian/European and African firms can be attributed to the effect of ethnic ties. The remaining 
difference may be explained by observed and unobserved characteristics that make Asian/European entrepreneurs a better credit risk.

Banerjee and Munshi (2004) present evidence for the importance of community effects in determining access to finance in the knitted garment industry in the city of Tirupur in Southern India. In this city, the Gounders, a group from a relatively wealthy agricultural community, were the first to move into the garment industry that provided better opportunities than agriculture. The emerging industrial activity also attracted outsiders from other regions and communities, who knew better about the business than the incumbent Gounders. Yet, the Gounders were using more capital-intensive production modes than the newcomers - despite being less productive. The authors argue that the shadow price of capital was substantially lower for the Gounders because of their stronger ties to the local community and the associated better access to finance.

The above overview illustrates the factors and mechanisms that minorities employ to succeed in business. We show that network effects can largely explain the dominance of ethnic minorities in business. Membership in a social/business network enables minority-run firms to obtain accurate information on potential business partners and employees and to enforce contracts without referring to formal institutions. They allow network members to participate in advanced forms of market exchange and to access resources important for successful business operation. While these mechanisms have been studied, both theoretically and empirically, in the economics literature, there is surprisingly little empirical evidence on interethnic differences in business outcomes (e.g. value added, profitability). One reason for this may be the political sensitivity of the topic. Ethnic bias in business has created social and political tensions in many developing countries. Therefore, in the next sub-chapter, we look at political actions aimed at reducing this imbalance and their effectiveness.

\subsubsection{Policies (of immigration and towards migrants)}

Although the minorities presented in section 3.2 dominate the private sector economically, they typically do not possess political power. Governments representing an economically disadvantaged majority population have acted in several ways to the economic imbalance. Many governments have pursued policies that combined affirmative action with state capitalism (Esman, 1987; Himbara, 1994). Examples include the 'New Economic Policy' launched by the Malay government in 1969 and the 'Africanisation' policies pursued by many African governments after independence. These policies typically comprised the following elements (Esman, 1987): 
(i) Expansion of higher education: Many Southeast Asian governments invested heavily in higher education to expand the educational opportunities of the economically disadvantaged majority. In some countries, this policy was accompanied by a system of ethnic preference. In Malaysia, the introduction of differential admissions criteria based on ethnic membership resulted in a shift in the Malay - non-Malay university enrolment ratio from 1:2 in 1968 to 3:1 in 1978.

(ii) Language policy: By imposing their mother tongue to be the language of operation in government, education and (where possible) the private sector, this community receives an advantage in educational and occupational competition. For example, the Nationalist Party in South Africa enforced in 1948 the constitutional requirement that civil servants be bilingual (English and Afrikaans) and thus created an employment preference for educated Afrikaners in the civil sector.

(iii) Government employment: Politicians expanded public sector employment, making it an area of explicit preference and preponderance for the majority group.

(iv) State economic enterprises: Governments created new public enterprises and took over existing companies (by purchase or nationalization). These public corporations were then staffed by members of the majority population. State capitalism was viewed as a necessary but transitory phase for the establishment of a viable native entrepreneurial class.

(v) Preferential economic assistance: Governments provided financial and other forms of economic assistance to promote private sector businesses owned by members of the dominant ethnic community. This kind of assistance was usually not offered to other firms. In many African countries, government parastatals were created with the tasks to acquire firms, provide loans and working capital to African businesses. Newly established banks or financial agencies were to specifically foster and encourage ethnically owned enterprises. The Government of Malaysia required all banks to reserve a proportion of their commercial loans to Malay-owned firms and insured these loans. In contracting for equipment, supplies, and services and in allocating franchises and licenses, governments favoured firms run by the ethnically preferred group.

(vi) Preferential employment in private enterprises: Governments employed licensing and other sanctions to compel firms owned and controlled by foreigners or by members of minority groups to increase the participation of members of the majority community in managerial positions. For instance, the Zambian Government granted road service 
licenses for commercial vehicles only to firms with at least 75 per cent Zambian ownership (Beveridge, 1974).

(vii) Restriction of economic opportunities for minorities: Some governments passed legislation that restricted the economic opportunities of non-African entrepreneurs. For example, Kenya introduced the Trade Licensing Act in 1967, which excluded nonAfricans from trading in rural areas and all noncentral parts of major cities. In 1971, the Zambian president Kaunda banned non-Zambians from all national trade except in 21 categories of goods.

Different combinations of all or several of these methods have been employed in various countries to reduce the economic imbalance between different segments of the population. They aimed at expanding the economic role of the ethnic majority by explicitly preferential methods, without destroying the economic position or incentives of the economically dominant ethnic minority.

There is almost no literature examining the effectiveness of these policy measures. One notable exception is Himbara (1994) who revisits the Africanisation of commerce and industry in Kenya during the 1970s. He concludes that the policy failed. For one, the parastatal organizations founded to foster native entrepreneurship did not possess the necessary technical skills nor the financial resources. Second, the fragmented nature of the Kenyan government created discontinuities in policy implementation. Operating in an ethnically and regionally divided environment, the incumbent government sought to consolidate its power by supporting an African business class from within their own ethnic ranks. A change in the regime often ended the economic support for the previously favoured ethnicity. Without state support, most businesses previously transferred to native entrepreneurs failed. Many local entrepreneurs lacked the skills and experience to successfully run these firms. In addition, in many African countries, the reforms were applied based on citizenship. Many Asians were second- or thirdgeneration immigrants and could claim African citizenship (Beveridge, 1974). Therefore, policies to transfer businesses owned by immigrant minorities to members of the majority population or ruling ethnicity brought about little change.

Other governments have aimed to end minority economic domination by such radical measures as expropriation of assets and even the expulsion of ethnic minorities. These strategies have, for instance, been employed in Uganda (against its Asian minority in 1972) and Vietnam (against its Chinese minority in 1979). Here, the economic consequences were felt more drastically. In Uganda, some 5,655 firms and farms were reallocated to Ugandan individuals or government bodies (Jørgensen, 1981). The Ugandan economy fell into a deep crisis under the 
strain of civil wars, the nationalization of certain industries and the expulsion of the Asian minority. In 1985, president Museveni assumed power in Uganda and thousands of Gujaratis returned to Uganda. Although the size of the Asian community decreased drastically, the economic imbalance remained. Immigrant minorities are still overrepresented in private sector ownership in Uganda and elsewhere, as the figures presented in Table 5 and Table 6 show.

\subsection{Conclusion}

This literature review provides an overview of the available evidence on the prevalence and economic performance of minority businesses in developing countries. Although minority business communities appear to exist in virtually all countries of the developing world, the literature focuses on immigrant minorities in sub-Saharan Africa and Southeast Asia. Immigrants (and their descendants) from South Asia, Lebanon and the Middle East, and China form the business communities that receive most attention. The majority of studies on the economic performance of minorities only present anecdotal evidence. We could identify a total of five economic contributions that used survey data to examine inter-ethnic differences in business outcomes (Banerjee \& Munshi, 2004; Biggs \& Shah, 2006; Gajigo \& Foltz, 2010; Mengistae, 2001; Ramachandran \& Shah, 1999).

Turning to the factors that may explain the economic dominance of minorities, the empirical evidence points to the importance of network effects. Business networks enable their members to circumvent problems of asymmetric information and contract enforcement. This gives them access to resources from which native businesses may be barred because of market imperfections. Credible empirical evidence is presented for ethnic bias in the access to informal credit (Biggs et al., 2002; Fafchamps, 2000; Fisman, 2003).

In addition to the benefits derived from community-based social networks, minorityowned businesses in developing countries may have had initial advantages in terms of relative resource endowments and beneficial state policies. Compared to the native population, migrant entrepreneurs often possess a higher human and financial capital endowment. Furthermore, colonial policies strengthened the economic position of migrant minorities by installing them as trade intermediaries between the indigenous population and the colonial power.

Because information sharing and contract enforcement can be ensured inside the business community, members are reluctant to deal with outsiders. As a result, minority business communities tend to reproduce themselves over time and end up excluding nonmembers from business transactions. Thus, initial comparative advantages of minority groups can lead to long-term market dominance. 
Partition of economic activity by networks limits the allocative efficiency of financial and human capital. Network members are compelled by virtue of their contacts to invest in particular businesses due to lower transaction costs. At the same time, outsiders may be reluctant to invest in these areas. Human capital formation can be affected too because the segregation of economic activities raises expected returns from human capital investments in economic sectors where one has connections and lowers them in activities where one lacks the corresponding network. In the same way, this connection-based reward structure can distort the allocation of scarce entrepreneurial resources, reducing innovation and new firm formation (Biggs \& Shah, 2006).

Moreover, this economic imbalance sparks social tensions. Therefore, after independence many governments have introduced policies to strengthen native businesses and to limit the economic power of minorities. Across regions, these policies - often consisting of a strong economic role of the state, affirmative action and economic restrictions for minorityoperated businesses - have failed to sustainably change the ethnic composition of business and negatively affected the economy. More thorough assessments of these policies and thus a sufficient evidence base for policy recommendations are missing. However, the strategies employed by minority business networks themselves point to fields of action. If, for instance, information asymmetry is the cause for discriminating against outsiders, measures can be taken to improve information for all businesses. This may be achieved through institutions, such as credit referral bureaus or product norms and standards.

Due to the relative absence of large hierarchies (firms and government agencies) and the weakness of those that are present, resource allocation through gift exchange and market transactions play a more important role in many developing countries than in developed economies (Fafchamps, 2004). This is particularly true for sub-Saharan Africa where market exchange is characterized by many intermediaries and small transaction values. Therefore, mechanisms that enable the entrepreneur to enforce contracts are even more valuable in developing countries than in developed economies. The higher prevalence of incomplete and imperfect markets in developing countries leads to a greater significance of the entrepreneur's ability to mobilize production factors. A third factor that may explain why minority-run businesses are more successful in developing than in developed countries is the rather stagnant, agriculture-based economy, particularly present in much of sub-Saharan Africa. In this environment, it is easier to rely on social network-based exchange than in more dynamic sectors that are subject to constant innovation and firm entry. In the latter type of industries, constant 
reshuffling of firms and agents ensures that refusing to deal with unknown firms is uneconomical (Fafchamps, 2001a).

The theoretical and empirical evidence presented above has to be taken with a pinch of salt: Models of ethnic entrepreneurship have probably exaggerated the unique advantage of certain groups because few studies are comparative - examining both ethnic and non-ethnic businesses (Aldrich \& Waldinger, 1990). In particular, the empirical literature suffers from data limitations as there are very few databases describing genuinely representative samples of minority entrepreneurs (Bates, 2011). Ethnicity remains a provoking issue in many countries and therefore many nationally representative surveys abstain from identifying the race/ethnicity of firm owners. Even if surveys explicitly aim to interview business minorities, respondents are often hesitant to reveal details about the economic performance of their businesses. Finally, there remains the challenge of establishing that the community effects are true community effects and not the effects of unobserved individual characteristics, which is poorly addressed by most empirical papers. 


\title{
CHAPTER 4
}

\section{The role of social capital in alleviating credit constraints: A study of entrepreneurs in Sri Lanka}

\author{
Anna Giolbas and Sarah Wiegel
}

\begin{abstract}
Lack of finance is a serious obstacle to firm investment in developing countries. High returns to capital at low levels of capital stock and high variations in firms' marginal returns to capital are signs for capital constraints and allocative inefficiency of production. Analysing a unique panel dataset of Sri Lankan micro and small firms, we show that access to family finance is significantly correlated with higher capital stocks and a more capital-intensive mode of production for entrepreneurs who cannot obtain finance on the formal credit market. This suggests that social capital plays a role in alleviating credit constraints.
\end{abstract}

Acknowledgements: The authors gratefully acknowledge funding by the Federal Ministry for Economic Cooperation and Development (BMZ) within the framework of the project "Employment, Empowerment and Living Standards", implemented in cooperation with the German Development Bank (KfW). The authors thank Jann Lay and participants of the internal GIGA seminar for helpful comments. 


\subsection{Introduction}

Recent studies consistently find high marginal returns at low levels of capital and significant heterogeneity in capital returns (De Mel et al., 2008; Dodlova et al., 2015; Grimm et al., 2012b; Kremer et al., 2011; McKenzie \& Woodruff, 2006, 2008). These studies conclude that credit constraints partly explain the high marginal returns. Lack of finance hampers investment: credit-constrained firms in developing countries have been shown to operate with low capital stocks (Banerjee \& Munshi, 2004; Dodlova et al., 2015; Grimm et al., 2012b). If credit is not directed towards its most productive use, this suggests important allocative inefficiencies and results in lower economic activity and growth.

The core reasons for why the credit market functions imperfectly are information asymmetries and weak contract enforcement. There is ample evidence that social networks may help in overcoming the information and enforcement problem. Entrepreneurs who can draw on their social network, are more likely to receive credit and at more favourable interest rates (Dinh et al., 2012; Grootaert et al., 2002; Okten \& Osili, 2004; Talavera et al., 2012). However, this advantage can come at the cost of "forced redistribution" that sets disincentives for economic success (Baland et al., 2011; Chi \& Nordman, 2018; Di Falco \& Bulte, 2011; Grimm et al., 2013; Hadnes et al., 2013).

This paper contributes both to the literature on the implications of capital constraints for firm growth and to the literature on the importance of social networks in access to finance. We analyse a unique panel dataset of micro and small entrepreneurs in Sri Lanka to show that differences in access to finance affect the level of capital employed in the business as well as the production technologies. We find that credit-constrained entrepreneurs with access to family finance operate with higher capital stocks and have a more capital-intensive production than those without any access to capital. For formally credit-unconstrained entrepreneurs, we do not see any effect of access to family finance on business outcomes. Our results are robust to using alternative definitions of credit constraints as well as to comparing entrepreneurs from the first asset quartile to entrepreneurs form the fourth asset quartile and to dividing the sample into formally and informally operating firms. Further, we show that the capital accumulation and capital intensity paths of credit-constrained enterprises with access to family finance are almost identical to those of formally credit-unconstrained enterprises. This implies that informal sources of finance are not necessarily inferior to formal ones. Credit-constrained firms without access to informal finance, however, never catch up to the level of capital stock and capital intensity of production of firms with either access to formal or informal finance. 
This paper is structured as follows. In the next section, we review the related literature. Section 4.3 presents the analytical framework. Section 4.4 describes the data. Section 4.5 presents the empirical analysis. The last section concludes.

\subsection{Review of the related literature}

This paper relates to two strands of literature. First, it adds to the growing research on capital constraints and their effects on the investment behaviour and production technology of micro and small enterprises. Second, it builds upon the literature that illustrates the importance of social networks in facilitating access to formal and informal sources of credit. Even though the two separate strands comprise a large body of theoretical and empirical literature, few studies exist that combine the research on social capital and access to credit with that of micro and small enterprise economic performance.

\subsubsection{The role of capital constraints for MSE growth}

Several recent studies find high returns at low levels of capital for small-scale activities in developing countries. In their experimental study, De Mel et al. (2008) provide randomly selected Sri Lankan micro enterprises with grants in order to measure the impact of the additional capital on business profits. They find that the positive income shock increased monthly business profits by five per cent, which is well above market interest rates for loans. Two similar experiments conducted by McKenzie and Woodruff (2008) in Mexico and Fafchamps et al. (2011a) in Ghana find monthly marginal returns of up to 30 per cent for urban retailers. Kremer et al. (2011) use data on stock-outs of mobile phone top-up cards to estimate the marginal rates of returns to inventory for small retail firms in rural Kenya. By calculating the expected marginal benefit from holding an additional unit and comparing this to the cost of obtaining an additional unit, they derive that the average shop in the sample could achieve an annual return of 113 per cent to a marginal increase in inventory. Non-experimental studies (Dodlova et al., 2015; Grimm et al., 2012b; McKenzie \& Woodruff, 2006) use semi- or nonparametric methods to estimate average marginal monthly returns to capital of about 15 per cent. All these studies not only find high marginal returns at low levels of capital but also significant heterogeneity in capital returns depending on the level of capital stock employed in the firm, and enterprise and owner characteristics.

Credit constraints are one cause of high returns to capital. Most of the cited studies provide at least indirect evidence for the presence of credit constraints by showing that more 
credit-constrained firms are also the ones obtaining higher returns. McKenzie and Woodruff (2008) interact the amount of the cash grant with different measures of whether or not a firm is credit-constrained. They find marginal returns to be higher for entrepreneurs who perceive access to finance as an obstacle to the growth of their business and for entrepreneurs who had never used formal finance or supplier credit. In addition, marginal returns are higher for more able entrepreneurs and for households with a high shadow cost of capital within the household, measured by housing amenities (McKenzie \& Woodruff, 2006) and the presence of paid wage workers (De Mel et al., 2008). More direct evidence for the importance of credit constraints is provided by Banerjee and Duflo (2014) who use variation in access to a targeted lending programme in India to study the use of subsidized credit. Assuming that constrained firms will use the directed credit to expand production while unconstrained firms will use it to substitute for other credit, they find that many of the firms in their study must have been severely creditconstrained and had high marginal rates of return to capital.

Other theoretical and empirical research has extended conventional models of firm investment behaviour to incorporate financial constraints in determining investment (e.g. Chirinko et al., 1999; Fazzari et al., 1988; Hubbard, 1998). Models of asymmetric information and incentive problems in capital markets have implied that information costs and internal resources influence the shadow cost of external funds for fixed investment. They find that, ceteris paribus, investment is significantly correlated with proxies for changes in net worth or internal funds. This correlation is most significant for credit-constrained firms (Hubbard, 1998). However, all these studies have looked at medium or large firms in developed economies.

The study of the South Indian garment sector by Banerjee and Munshi (2004) provides a notable exception. It documents large and systematic differences in both levels of capital stock and the capital intensity of production in firms owned by members of two different communities. An established local group, the Gounders, who are relatively wealthy and were the first to move into the garment industry, dominates the industry. In addition, they are connected though kin relations that facilitate access to finance. The authors find that entrepreneurs in the garment industry who are not from the Gounder community start out with much lower levels of capital stock. After about seven years, the outsiders catch up with the Gounders but they do not overtake them with regard to the level of capital stock despite being more productive. The authors attribute these differences in capital intensity of production to differences in access to capital provided by the respective communities. Grimm et al. (2012b) examine the effects of capital market imperfections on capital stocks of informal MSEs in Western Africa. They find that credit-constrained MSEs start with much lower capital stocks 
than unconstrained entrepreneurs. Credit-constrained firms seem to be able to reach their optimal capital stocks as the enterprise grows older. However, the MSE age profiles suggest that only few firms reach the necessary age of eight to ten years. In their analysis of Peruvian micro enterprises, Dodlova et al. (2015) confirm that credit constraints, proxied by non-business household wealth, can partly explain low initial capital stocks and slow capital accumulation in these firms.

We follow this line of research by investigating the effects of capital constraints on capital accumulation and production technologies of micro and small enterprises in Sri Lanka. Yet, we combine this research question with an analysis of the role of the entrepreneur's social network in affecting business dynamics. More specifically, we examine to what extent the entrepreneur's social network can alleviate existing formal credit constraints by looking at differences in business outcomes between unconstrained and formally constrained entrepreneurs with and without access to family finance. For this purpose, we first introduce the existing literature on the role of the social network in providing access to finance.

\subsubsection{The role of social networks in access to credit}

Whenever contracts are not perfectly enforceable and reputation mechanisms are weak, social network-based economic exchange is relevant (Fafchamps, 2004). Personal acquaintance reduces the problem of asymmetric information and repeated interactions ensure that the selfenforcement of contracts is possible through second-party punishment (Greif, 1993). Many studies illustrate the importance of social networks in making available (in)formal credit and other types of mutual insurance (Carter \& Castillo, 2005; Fafchamps \& Gubert, 2007; Fafchamps \& Lund, 2003).

In a sociological study, Uzzi (1999) analyses bank-borrower relationships of US firms in the late 1980s. He finds that firms employing a mix of commercial transactions and social relations with bankers benefit regarding the likelihood of receiving a bank loan and of receiving lower interest rates on loans. Using trust as a proxy for social capital, Guiso et al. (2004) find that in areas of Italy where trust is high, firms are more likely to receive formal credit. In areas where trust is low and, hence, where people rely more on transactions within narrow groups of families and friends, informal loans are more important. In a recent study, Mistrulli and Vacca (2015) make use of an exogenous variation in the degree of information asymmetry and uncertainty induced by the Lehman Brothers bankruptcy to study the effect of social capital on the Italian credit market. They find that the rise in the cost of capital following the crisis was less severely felt by small firms with high social capital. In a study of 175 corporations from 16 
developed countries, Kim et al. (2014) find that similarities in the social responsibility engagement between borrowers and lenders are reflected in a lower price of credit for the latter.

In a case study on China, Talavera et al. (2012) find that social capital increases the likelihood for entrepreneurs to obtain bank credit. They proxy social capital with contributions to charities and time spend on social activities. Dinh et al. (2012) carry out a personal network survey to measure whether different forms of social capital affect credit access of rural households in Vietnam. According to their analysis, social capital has no significant influence on the likelihood of being credit-constrained but strong ties to persons of higher social standing ("bridging-link social capital") significantly reduce the magnitude of households' credit constraints. Okten and Osili (2004) investigate how family and community networks affect individual access to credit institutions in Indonesia. Their results indicate that networks are particularly important in gaining knowledge about new credit sources, thus suggesting an information-based explanation of the role of networks in credit market transactions. Grootaert et al. (2002) find that Burkinabe households whose members are active in community associations are more likely to have borrowed and they received larger amounts of credit.

There is also empirical evidence that social networks enhance the economic performance of micro and small enterprises. Using panel data on household enterprises in Vietnam, Kinghan and Newman (2015) show that social capital, in the form of union membership and trust in others, not only increases the probability that the household operates a firm, but it also increases the enterprise's profitability. Fafchamps and Minten (2002) study empirically the implications of social capital on business outcomes using the example of agricultural traders in Madagascar. They define social capital as the number of traders known by the entrepreneur and find that a larger network has positive and significant effects on value added and sales. They conclude that social capital allows traders to grant and receive credit, exchange price information and economize on quality inspections. In contrast, Barr (2002) finds that small firms in the Ghanaian manufacturing sector are characterized by "solidarity networks" that reduce income variability but have little impact on economic performance. Other studies show that ethnic ties facilitate access to trade credit (Biggs et al., 2002; Fafchamps, 2000; Fisman, 2003). Woodruff and Zenteno (2007) show that affiliation to migration networks is associated with a significantly higher rate of investment and higher capital-output ratios among micro enterprises in Mexico. Higher investments are also correlated with higher business profits and, at least in more capital-intensive sectors, with higher sales. These results are consistent with the sort of community effects found by Banerjee and Munshi (2004). 
Membership in a wealthier community leads to higher investment, suggesting that members of this community face lower costs of capital.

In a study of rural households in Sri Lanka, Shoji et al. (2012) explore the reverse causality, namely, the effect of credit constraints on social capital formation. They find that credit-constrained households invest less in social capital, i.e. they spend less on ceremonies and participate less in community irrigation maintenance. Moreover, the authors find that contribution to these public goods is correlated with the level of trust. If trust and trustworthiness in turn facilitate the access to credit, being credit-constrained may initiate a poverty trap.

While the majority of studies stress the positive effects of social capital, some others have found negative incentive effects for investment through forced redistribution to the kin (Baland et al., 2011, 2016; Chi \& Nordman, 2018; Di Falco \& Bulte, 2011; Grimm et al., 2013; Hadnes et al., 2013). The heterogeneous returns to social capital seem to depend on the composition of the social network and the study region. The literature distinguishes between "bridging social capital" that involves links cutting across diverse social groups and is frequently associated with improved access to resources (Putnam, 2000; Woolcock, 2001). In contrast, "bonding social capital" involves social ties between members of a relatively homogeneous and closed group (e.g. family and kinship) for which some empirical studies document negative incentive effects on entrepreneurship. Whereas the kin system in East Asia is largely considered to have spurred entrepreneurship, there is some evidence of negative effects of the kin system on productive activities in African firms (Hoff \& Sen, 2006).

The main challenge when examining the role of capital constraints for MSE growth and the role of social networks in access to credit is to cleanly identify the effects of credit constraints or affiliation to social networks. Both relationships are likely to be characterized by reverse causality and it is difficult to identify any exogenous shocks on access to finance or the social network composition.

\subsection{Analytical framework}

\subsubsection{Capital accumulation under credit constraints}

We illustrate the demand for capital under perfect capital markets in Figure 1. 
Figure 1: Capital stock under perfect capital markets

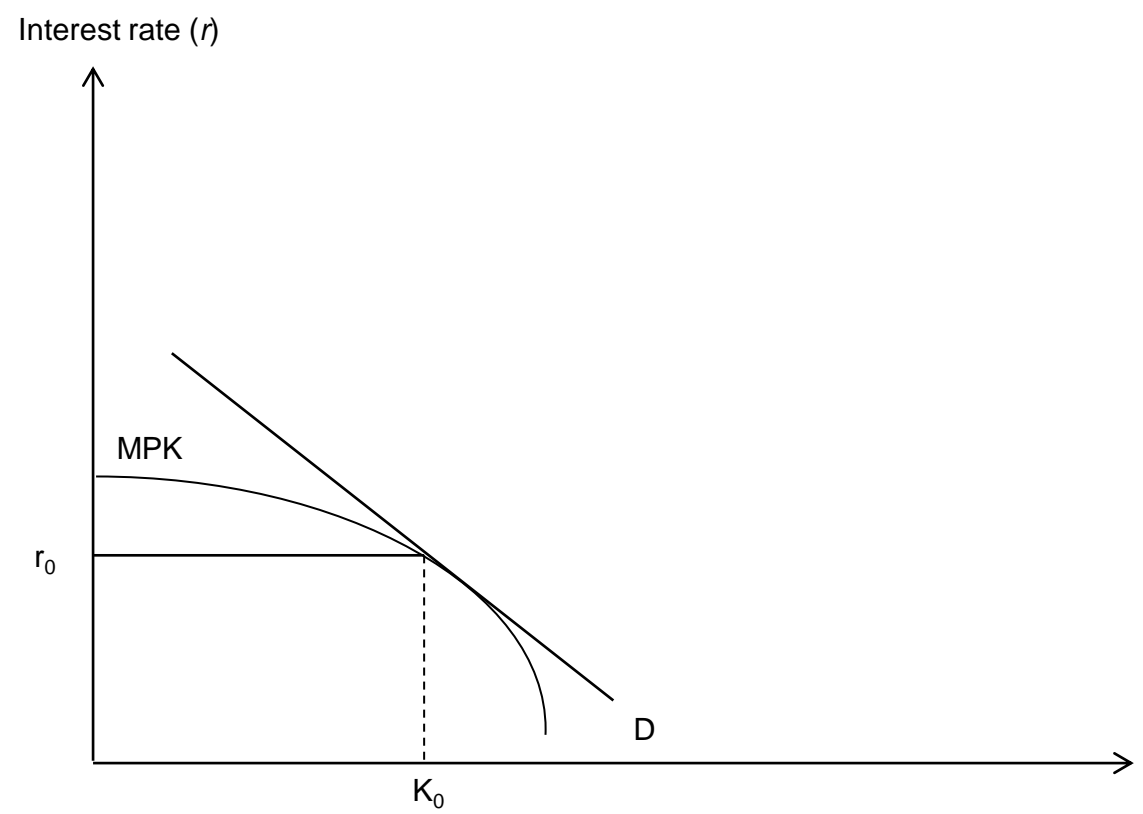

Capital stock $(K)$

Source: Authors' own illustration.

The horizontal axis measures the quantity of capital $(\mathrm{K})$ and the vertical axis represents the cost of capital (r). The demand curve (D) slopes down; an increase in the cost of capital reduces the firm's desired capital stock. The supply of capital (S) is a function of:

$$
\mathrm{K}_{\mathrm{i}}=\mathrm{g}(\mathrm{W}, \mathrm{B}, \mathrm{F})
$$

where the subscript $\mathrm{i}$ indexes the entrepreneur and $\mathrm{W}$ is the entrepreneur's wealth or savings ${ }^{8}$, $\mathrm{B}$ represents access to bank loans and $\mathrm{F}$ access to informal loans, e.g. from the (extended) family. The amount of capital invested in the firm then depends on both the demand for capital and its supply. Under the standard perfect capital market assumption, firms face a horizontal supply curve of capital at a single fixed interest rate. In this case, the first-best capital stock, $\mathrm{K}_{0}$, is determined by the intersection of the demand and supply curve at the interest rate $\mathrm{r}_{0}$. At point $\mathrm{K}_{0}$, the marginal return to capital equals the market interest rate. This is depicted by the concave curve MPK representing the marginal product of capital, $f(K)$. The marginal return to capital will be the same for all firms and will not depend on the characteristics of the entrepreneur or his/her household. The location of the demand curve is determined by the cost of capital and its expected future profitability. If, for instance, ability and capital are complements the expected future profitability of capital will be higher for high-ability entrepreneurs and they will desire to invest more capital. Under perfect capital markets, internal and external financing are perfect

\footnotetext{
${ }^{8}$ Wealth or savings may include business profits that are reinvested in the enterprise. Fazzari et al. (1988) develop a framework where reinvestment of cash flow allows a credit-constrained firm to adjust towards its optimal capital stock over time. This suggests that firm age will affect the level of investment. The business cycle might affect investment levels as well through its impact on cash flows.
} 
substitutes and changes in net worth or cash flow variables (e.g. profits) should be irrelevant for the investment decision.

We now abandon the assumption of perfect capital markets. Problems of asymmetric information between borrowers and lenders and the resulting risk of moral hazard or adverse selection lead to credit rationing and result in a wedge between the costs of external and internal financing (Hubbard, 1998). This has two implications. First, a firm faces different interest rates depending on the source of credit. Second, the costs of capital from each source may vary between entrepreneurs, e.g. due to different capacities to provide collateral. This results in a step (or linear upward sloping) capital supply curve as depicted in Figure 2. The slope of the supply curve reflects the information costs related to external financing. In the case represented here, we assume that the firm uses $K_{w}$ units of internal wealth at the interest rate $r_{w}$. It borrows additional capital from the bank at the higher interest rate $r_{B}$. A firm is credit-constrained if the total amount of capital invested by the firm is less than the amount it would want to invest given the highest interest rate it is currently paying. In Figure 2, the firm would like to invest the amount $\mathrm{K}_{\mathrm{B}}$ where the marginal product of capital equals the interest rate. However, as credit constraints bind the firm, it can only borrow a maximum amount of $\mathrm{K}_{1}$ and thus operates with suboptimal levels of capital. It is now easy to see that under credit constraints an increase in the entrepreneur's wealth and/or cash flow will expand his/her use of capital.

Figure 2: Capital stock under imperfect capital markets

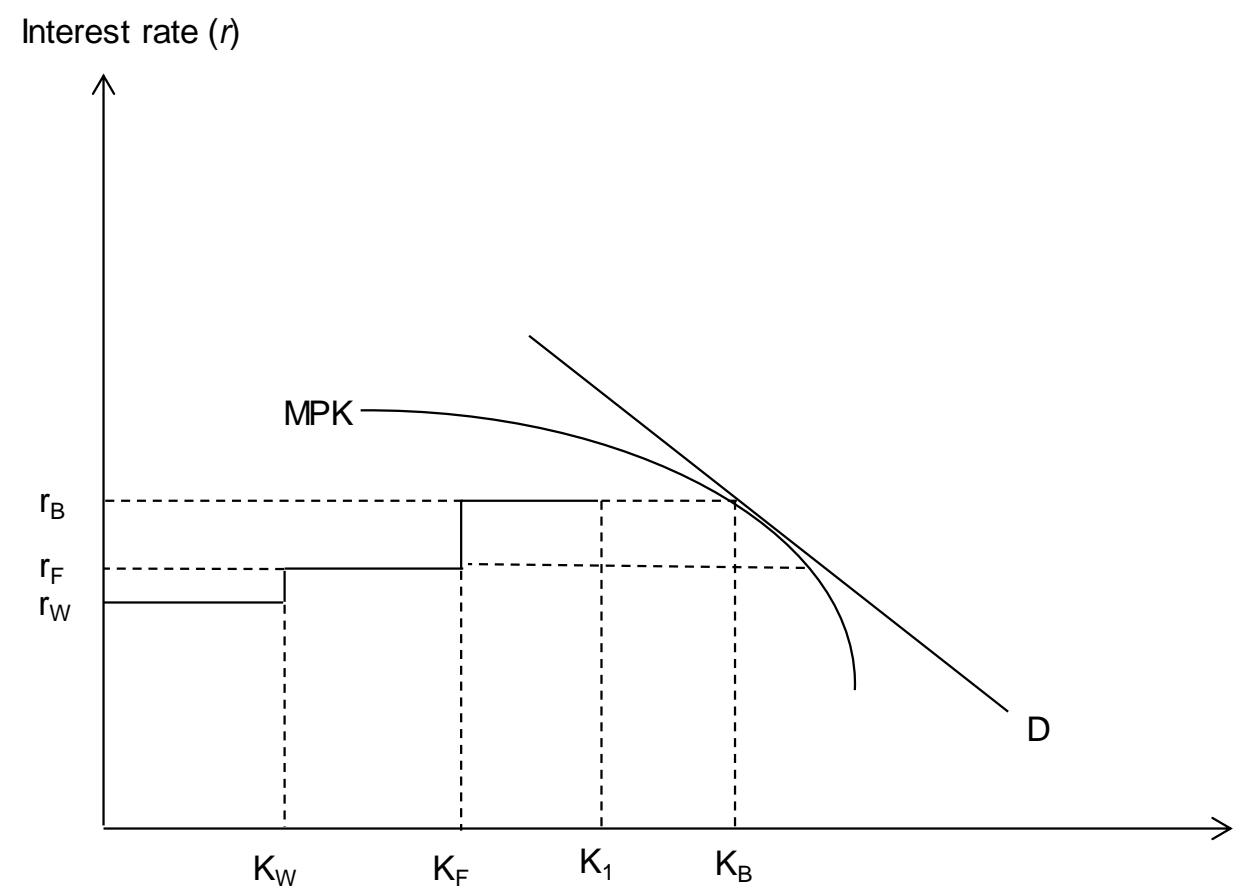


In our example, the entrepreneur cannot only access internal finance and (limited) bank credit but can also borrow capital from the kin at the interest rate $\mathrm{r}_{\mathrm{F}}$. Given that the family usually has more information about the creditor than formal banking institutions and that for them monitoring may be less costly, there is reason to believe that $r_{F} \leq r_{B}$. However, it is also possible that social norms, etc. result in higher interest rates for family credit. Access to family finance may not only change the capital costs for the entrepreneur but also alleviate credit constraints if a formally credit-constrained entrepreneur can obtain the desired amount of capital from the kin. If $\mathrm{r}_{\mathrm{F}} \leq \mathrm{r}_{\mathrm{B}}$, the entrepreneur would like to invest even more than $\mathrm{K}_{\mathrm{B}}$. In either case, we expect access to family finance to be positively correlated with the capital stock of the firm.

We expect credit-constrained firms to increase their capital stock over time by investing retained profits. Capital stocks would then be increasing with firm age and should increase faster if profits are high. To sum up, we describe the current level of capital stock as a function of the optimal "steady-state" capital (denoted $\mathrm{K}^{*}$ ), enterprise profits, wealth, ability, firm age and access to family finance. We further hypothesize that profits, wealth and access to family finance only matter for determining the capital stock of formally credit-constrained entrepreneurs.

$$
\mathrm{K}=\mathrm{g}\left[\mathrm{K}^{*}(\mathrm{~W}[+]) \text {, ability }[+], \mathrm{W}[+] \text {, profits }[+] \text {, family finance }[+] \text {, firm age }[+]\right]
$$

\subsubsection{Choosing a production technology under credit constraints}

In the last section, we have shown that formally credit-constrained entrepreneurs may face different costs of capital, which in turn causes some firms to operate with suboptimal levels of capital. Alternatively, the capital-constrained entrepreneur may choose to invest in different technologies (Banerjee \& Duflo, 2005). Therefore, we expect that credit constraints and access to alternative sources of capital will also influence the capital-output - and the capital-labour ratio. The capital-labour ratio is determined by the costs of capital (r) and labour (w) as well as the output elasticities of the two input factors. Assuming a Cobb-Douglas production function $Y_{i}=A_{i} K_{i}^{\alpha} L_{i}^{1-\alpha}$ where $\mathrm{A}_{\mathrm{i}}$ is firm-level total factor productivity, $\mathrm{K}_{\mathrm{i}}$ is capital and $\mathrm{L}_{\mathrm{i}}$ is labour input, the capital-labour ratio is given by

$$
\frac{K_{i}}{L_{i}}=\frac{\alpha}{1-\alpha} \frac{w}{r}
$$

Ceteris paribus, as the cost of one input increases it will be used less in the production process. Due to imperfect capital markets, we must add a shadow price to the factor price of capital. If we assume that own wealth and access to family finance reduce the cost of capital (or expand its use) we expect to find a positive correlation between these variables and the capital-labour 
ratio. Similarly, the use of more family labour lowers labour costs (because contributing family members are typically not paid) and results in a decreasing capital-labour ratio.

\subsection{Descriptive Statistics}

We use micro firm-level survey data of about 518 entrepreneurs, collected in Colombo, Sri Lanka between 2012 and 2014. We have panel data consisting of three survey waves. The conditional attrition rate is 4.2 per cent between the first (2012) and the second wave (2013) and 4.6 per cent between 2013 and 2014. The data provide detailed information about the entrepreneur, his/her household and extended family as well as firm characteristics, such as the employed labour force, physical capital, investment and sources of finance.

Before turning to a description of the data, we briefly describe the sampling procedure. Many micro and small enterprises in Colombo are unregistered, so that there is no comprehensive sampling frame available. Given our resource constraints, we were unable to conduct a firm census of the entire city, which would have allowed us to randomly sample firms for the survey. Instead, we focused on areas in which production units are known to be concentrated. In cooperation with the local administration, we classified 56 clusters within Colombo district as "predominantly business". From this list, we randomly chose 35 clusters for a complete listing until reaching 4,000 enterprises. In a second step, we randomly drew a sample of 514 firms from predefined industry sectors. From the trade sector, we randomly selected 200 enterprises, oversampling the two more homogeneous sub-sectors "retail/wholesale of phones, electrical and household appliances" and "retail/wholesale of clothes and second-hand clothes". We randomly sampled 200 enterprises from the manufacturing sector, oversampling "textile and wearing apparel manufacture", "manufacture of furniture" and "manufacture of wood and cork". In addition, we amended the sample by randomly selecting 50 enterprises from the "hairdressing and beauty" service sector. Furthermore, we stratified the sample according to whether a firm is a branch. In order to have a meaningful sample of branch firms, we went beyond the above (sub-)sectors and sampled all branches of a firm, whenever possible.

Our data offer several options to define credit-constrained firms. Our primary differentiation follows Shoji et al. (2012) and defines all entrepreneurs as formally creditconstrained who have applied for a formal loan and have not been granted it or have not been granted the full amount that they applied for. Additionally, all entrepreneurs who have never applied for a formal loan out of other reasons than no need are coded as credit-constrained. 
Entrepreneurs are asked these questions in each survey year so that this measure can vary over time for the same individual. Figure 3 illustrates the coding of the credit-constrained variable.

Figure 3: Definition of variable measuring formal credit constraints

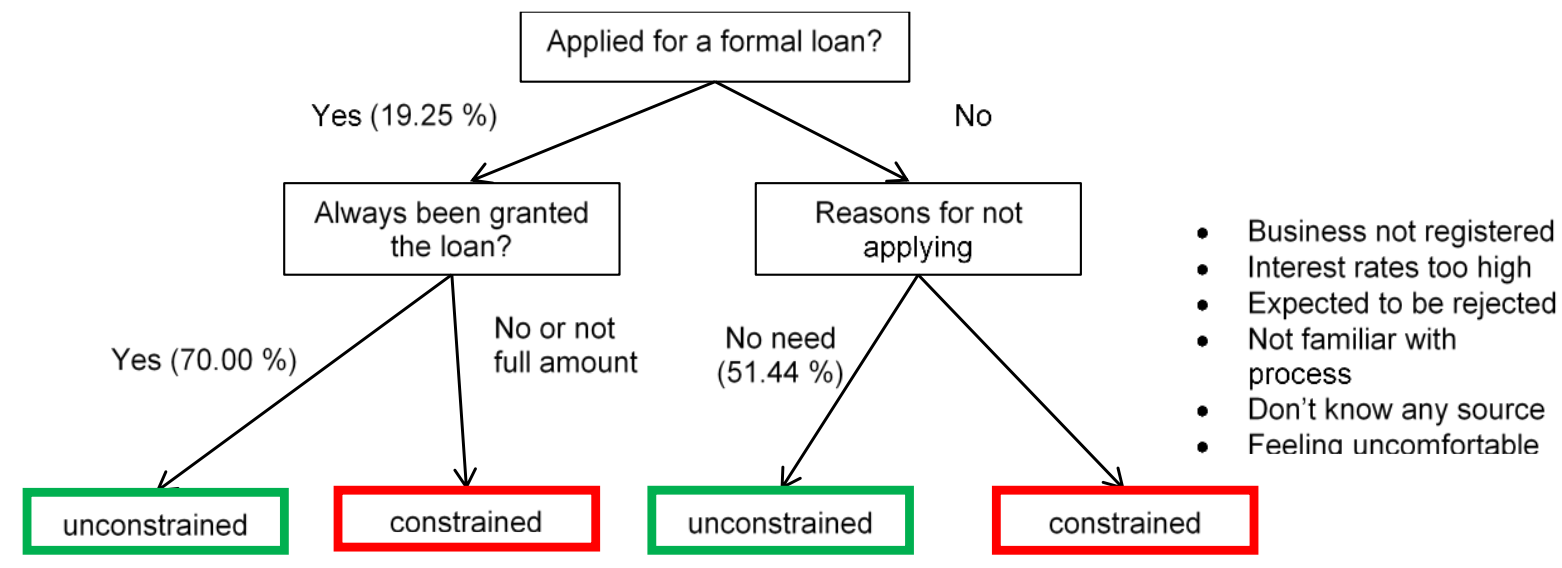

Source: Authors' own illustration.

We partition the sample into credit-constrained and unconstrained entrepreneurs and present some key characteristics of the entrepreneurs and their firms in Table 7. The median selfreported monthly profit is about Rs. 29,500 ( $\approx$ Int. \$ 663). The sampled entrepreneurs report owning a median physical capital stock of Rs. 73,147 (valued at replacement cost), equal to Int. \$ 1,644. The measure of physical capital includes machines, furniture, vehicles and tools but excludes land and buildings 9 . The distributions of capital stock and profits are heavily skewed. Median values are much smaller than the respective means. Median investment, measured as the difference in capital stock between the current and the previous year, is actually negative, implying that the median entrepreneur is liquidating his/her business assets. However, respondents are asked to state the replacement value of each business asset in every survey wave and intra-item variance is quite pronounced. Changes in the physical capital stock over time might therefore also reflect differences in the respondent's valuation of his/her business assets rather than actual acquisitions or sales.

Credit-constrained und unconstrained entrepreneurs and their firms differ from each other along various characteristics. Credit-unconstrained entrepreneurs are on average better educated and manage larger firms, measured by the number of employees. Differences in firm capital stocks and profits are very large between both groups. The mean capital stock (incl.

\footnotetext{
${ }^{9}$ Land and buildings are excluded because of high measurement error in the data.
} 
inventories) and profits of an unconstrained business are more than twice the amount of the average values for a credit-constrained firm. Examining the sector composition of our sample, we find a larger number of the credit-constrained firms manufacturing wood and furniture while unconstrained firms are more often active in services.

Table 7: Basic sample characteristics by access to capital

\begin{tabular}{|c|c|c|c|}
\hline & $\begin{array}{l}\text { Not credit- } \\
\text { constrained }\end{array}$ & $\begin{array}{c}\text { Credit- } \\
\text { constrained }\end{array}$ & T-test \\
\hline & Mean & Mean & Difference \\
\hline \multicolumn{4}{|l|}{ Individual characteristics } \\
\hline Entrepreneur's age & 44.3 & 44.8 & -0.6 \\
\hline $\begin{array}{l}\text { Share of entrepreneurs that have not } \\
\text { completed primary education }\end{array}$ & 0.0 & 0.1 & $-0.0 * * *$ \\
\hline $\begin{array}{l}\text { Share of entrepreneurs with completed } \\
\text { primary education }\end{array}$ & 0.2 & 0.3 & $-0.1 * * *$ \\
\hline $\begin{array}{l}\text { Share of entrepreneurs with completed } \\
\text { secondary education }\end{array}$ & 0.4 & 0.4 & $0.1 * *$ \\
\hline $\begin{array}{l}\text { Share of entrepreneurs with completed } \\
\text { tertiary education }\end{array}$ & 0.3 & 0.2 & $0.1 * * *$ \\
\hline Entrepreneur's experience & 13.0 & 13.2 & -0.2 \\
\hline Entrepreneur is male & 0.8 & 0.8 & -0.0 \\
\hline \multicolumn{4}{|l|}{ Firm characteristics } \\
\hline MSE age & 14.4 & 14.9 & -0.5 \\
\hline No. of employees (excl. the entrepreneur) & 1.7 & 1.1 & $0.6^{* * *}$ \\
\hline Monthly profit (in $2012 \mathrm{Rs}$ ) & $89,088.4$ & $46,107.9$ & $42,980.4 * *$ \\
\hline $\begin{array}{l}\text { Owned capital stock, excl. land and } \\
\text { buildings (in } 2012 \mathrm{Rs} \text { ) }\end{array}$ & $1,243,613.6$ & $729,970.7$ & $513,642.9^{*}$ \\
\hline $\begin{array}{l}\text { Owned capital stock, excl. inventories, land } \\
\text { and buildings (in } 2012 \mathrm{Rs} \text { ) }\end{array}$ & $612,000.3$ & $237,462.4$ & $374,537.9 * *$ \\
\hline \multicolumn{4}{|l|}{ Industry sectors } \\
\hline Manufacture of textiles & 0.1 & 0.1 & -0.0 \\
\hline Manufacture of wood and furniture & 0.2 & 0.3 & $-0.1 * * *$ \\
\hline Other manufacturing & 0.1 & 0.1 & -0.0 \\
\hline Wholesale and retail of food and beverages & 0.1 & 0.1 & -0.0 \\
\hline Wholesale and retail of electronics & 0.1 & 0.1 & 0.0 \\
\hline Wholesale and retail of wearing apparel & 0.1 & 0.1 & $0.0^{*}$ \\
\hline Other wholesale and retail & 0.3 & 0.3 & -0.0 \\
\hline Hairdressing and beauty & 0.1 & 0.1 & $0.0^{*}$ \\
\hline Other services & 0.1 & 0.1 & $0.1 * * *$ \\
\hline Observations & 793 & 675 & 1468 \\
\hline
\end{tabular}

Notes: ${ }^{*} p<0.10,{ }^{* *} p<0.05,{ }^{* * *} p<0.01$

It can be argued that entrepreneurs who have never applied for a formal loan because they have no need for it are substantially different from those who have applied and been granted a loan. 
Then, defining the two groups jointly as credit-unconstrained would result in wrong conclusions. We experiment with an alternative definition of credit constraints that follows Bigsten et al. (2003b). Besides those entrepreneurs who have always been granted bank loans (unconstrained) and those who have not been granted loans or were discouraged from applying (constrained), we create a third group of entrepreneurs which consists of all those who state that they have no need for a loan (no demand). However, unlike Bigsten et. al. we code entrepreneurs who have not applied for a loan due to high interest rates as credit-constrained. We assume that screening and monitoring costs make credit too expensive for them and therefore, these entrepreneurs are indeed suffering the consequences of market imperfections. In addition, they are more similar in their average number of employees, profits and capital stock to the constrained group than to the no demand group. According to this definition, about 13 per cent of entrepreneurs in our sample would be in the unconstrained group, 46 per cent would be coded as credit-constrained and 41 per cent would be in the no demand group. Comparing the unconstrained group with the entrepreneurs declaring no demand for credit, we indeed find significant differences in firm characteristics. Firms in the no demand group are significantly smaller, both in terms of employees and capital stock (see Table A. 1 in the Appendix). They are more often engaged in wholesale and retail of electronics and less often involved in manufacturing of wood and furniture compared to those entrepreneurs who have always been granted the loan.

So far, we have only focused on formal loans. Yet, informal loans by business partners, relatives or moneylenders play an important role for micro and small entrepreneurs in Sri Lanka. About 60 per cent of formally credit-constrained entrepreneurs also do not have access to informal credit. That is, 28 per cent of our sampled entrepreneurs are both formally and informally credit-constrained. Only 19 per cent of those without demand for formal credit have applied for credit from informal sources.

Our sampled entrepreneurs rely largely on own savings as source of business finance. 87 per cent cover their expenditures for raw materials and finished goods by their business savings/profits and over 43 per cent of the entrepreneurs financed the start-up of their business completely through their own savings. Yet, formal and informal sources of capital play an important role for business investments (see Table 8). Almost one fourth of all entrepreneurs received capital from family members to set up their business. Formal (comprising bank and microfinance loans) and trade loans (from suppliers or customers) are the most prevalent credit sources for our sample of micro and small entrepreneurs in Colombo, Sri Lanka. Among those borrowing, the average number of loans is 1.4 per entrepreneur. Entrepreneurs obtain much 
higher loan amounts with longer repayment periods from formal than from informal credit sources. The fact that despite the high mean annual nominal interest rate of 63 per cent for loans from moneylenders, more than 6 per cent of entrepreneurs in our sample have such a loan indicates that marginal rates of return to capital must be very high, at least for some of the entrepreneurs. Entrepreneurs that pay interest on trade loans or loans from family and friends are also confronted with rather high mean annual nominal interest rates ranging from 28 per cent (for loans from friends) to 53 per cent (for trade loans).

Table 8: Business loan statistics by type of loan

\begin{tabular}{lccccc}
\hline \hline & Family loan & Formal loan & Trade loan & $\begin{array}{c}\text { Loan } \\
\text { from } \\
\text { friends }\end{array}$ & $\begin{array}{c}\text { Loan from } \\
\text { moneylender }\end{array}$ \\
\hline $\begin{array}{l}\text { \% of entrepreneurs who received } \\
\text { capital to start business }\end{array}$ & 24.31 & 4.68 & 1.90 & 4.05 & 1.77 \\
$\begin{array}{l}\text { \% of entrepreneurs who currently } \\
\text { have a loan }\end{array}$ & 3.28 & 18.06 & 18.56 & 8.40 & 6.44 \\
Mean value of loan (in Rs) & 152,302 & $1,418,813$ & 258,000 & 160,078 & 159,569 \\
Median value of loan (in Rs) & 50,000 & 350,000 & 75,000 & 100,000 & 50,000 \\
Mean payback period (in years) & 1.07 & 4.10 & 0.87 & 1.31 & 0.95 \\
Mean annual nominal interest (\%) & 21.18 & 18.54 & 15.00 & 13.84 & 62.81 \\
\% of zero interest loans & 35.19 & 0.98 & 72.34 & 45.64 & 1.72 \\
\hline Observations & 54 & 307 & 376 & 149 & 116 \\
\hline \hline
\end{tabular}

Table 9: Business loan statistics by credit constraint status

\begin{tabular}{lcccccc}
\hline \hline & \multicolumn{3}{c}{$\begin{array}{c}\text { Not credit-constrained } \\
\text { (obs. = 833) }\end{array}$} & \multicolumn{2}{c}{ Credit-constrained (obs. = 701) } \\
\hline & Obs. & Mean & S.D. & Obs. & Mean & S.D. \\
\hline Family loans (Rs.) & 25 & 224,080 & 316,399 & 28 & 88,214 & 125,976 \\
Annual nominal interest (\%) & 15 & 31.98 & 54.70 & 23 & 14.14 & 20.92 \\
Formal loans (Rs.) & 211 & $1,475,062$ & $2,791,704$ & 92 & $1,308,967$ & $4,214,628$ \\
Annual nominal interest (\%) & 192 & 20.11 & 74.39 & 82 & 15.07 & 16.10 \\
Trade loans (Rs.) & 184 & 352,270 & $1,878,702$ & 189 & 164,546 & 374,675 \\
Annual nominal interest (\%) & 174 & 10.25 & 35.31 & 180 & 19.00 & 56.08 \\
Loans from friends (Rs.) & 66 & 189,700 & 204,026 & 81 & 137,858 & 248,220 \\
Annual nominal interest (\%) & 60 & 10.33 & 27.81 & 72 & 16.14 & 22.53 \\
Loans from moneylender (Rs.) & 29 & 200,724 & 287,564 & 86 & 145,221 & 258,986 \\
Annual nominal interest (\%) & 26 & 44.04 & 47.94 & 76 & 69.75 & 78.06 \\
\hline
\end{tabular}

Table 9 displays some loan characteristics for credit-constrained and unconstrained entrepreneurs separately. As expected, credit-constrained entrepreneurs have significantly fewer formal loans and rely more on informal loans. The loan amount in the constrained group is smaller than in the unconstrained group for all credit sources. However, the mean annual 
nominal interest rate paid by credit-constrained borrowers for family and, surprisingly, for formal loans is lower than in the unconstrained sample.

If we compare the use of different funding sources by capital quartiles (Table A. 2 in the Appendix), we see that firms in the highest capital quartile (with a capital stock of Int. \$3,969-1,577,761) rely most on own savings or retained profits for their investments. Yet, looking at the importance of funding sources as measured by their percentage contribution to total finance (Table A. 3 in the Appendix), own savings constitute the largest part of start-up capital for firms with the lowest capital stock. Firms in the lowest capital quartile more often use loans from moneylenders to finance start-up costs or inventory despite their high interest rates, suggesting a lack of alternative funding sources. Surprisingly, the use of family loans and their portion in the aggregate amount is the smallest for low-capital enterprises. As this group comprises the highest share of formally capital-constrained entrepreneurs, we would have expected that they rely more heavily on family loans. The use and importance of formal loans increases with the firms' capital stock for start-up finance but not so for inventory investments.

\subsection{Empirical analysis}

We aim to show that differences in access to finance affect the level of capital employed in the business as well as the production technologies by testing empirically the following specification:

$$
y_{i t}=\beta_{0}+\beta_{1} \text { familyfinance }_{i t}+\beta_{2} \text { familylabour }_{i t}+\beta_{3} X_{i t}+u_{i t}
$$

where $y_{i t}$ is either log capital stock, log capital-output ratio or log capital-labour ratio. The capital-output ratio is defined as the total capital invested in the firm divided by gross sales in the month before the survey. The vector of exogenous control variables $\mathrm{X}_{\mathrm{it}}$ includes education of the entrepreneur, firm age and its squared term, a 1-year lag of the standardized household asset index, a 1-year lag of log monthly self-reported profits as well as sector and year dummies. $\mathrm{u}_{\mathrm{it}}$ is the error term that captures all omitted variables and random errors. We split the sample into credit-constrained and unconstrained entrepreneurs and estimate the above equation separately for each sample. We take this approach because we have reason to believe that the underlying model for the two groups is substantially different.

Whereas the degree of access to finance varies between entrepreneurs, we assume all firms face the same labour constraints. This assumption is likely to hold true in a developing country context where all firms are confronted with problems of limited contract enforceability and a frequent mismatch in labour supply and demand. 
The variable of interest in this specification is a dummy variable equal to one if (part of) the money required to start or take over the business came from gifts/inheritances/loans made by household members or other relatives or if the entrepreneur has a current loan from a family member. This variable measures whether the entrepreneur has access to family finance. In a world with perfect capital and labour markets, the source of finance should not affect business outcomes. However, if family finance alleviates credit constraints, it may have a positive impact on business outcomes. Thus, we expect to find a positive and significant correlation between access to family finance and our dependent variables only for the creditconstrained sample. Similarly, the credit-constrained entrepreneurs can use their non-business assets and retained profits to finance investments and move towards their optimal capital stock/production technology.

The second variable of interest is the share of family labour in total labour in terms of working hours ${ }^{10}$. If family employees are relatively inexpensive and easy to recruit, entrepreneurs may decide to shift towards a more labour-intensive production. Consequently, we expect a negative relationship between family labour and the capital-labour ratio. This effect is likely to be stronger for firms who face difficulties obtaining capital.

Table 10 reports the estimates of the above-mentioned specifications using pooled OLS for credit-constrained and unconstrained firms, respectively ${ }^{11}$. Due to the use of lagged explanatory variables, we lose a significant number of observations, i.e. the total sample size drops from 1,483 to 771 observations for logged capital stock as the dependent variable. For one, we lose all information from the 2012 survey wave. In addition, all firms that participated only in one survey year are dropped.

For credit-constrained firms we find a large, positive and significant correlation between access to family finance and the capital stock, the capital-output-ratio and the capital-labour ratio. Keeping all other variables constant, receiving finance from the family increases the geometric mean of the capital stock by 26 per cent, the capital-output-ratio by 23 per cent and the capital-labour ratio by 26 per cent for credit-constrained entrepreneurs. In contrast, access to family finance has no effect on the unconstrained firms. Against our expectations, the

\footnotetext{
${ }^{10}$ The entrepreneur's own labour input is not included in family labour. Hence, the share of family labour over total labour equals 0 if the entrepreneur is an own-account worker.

${ }^{11}$ In all regressions, we drop influential outliers from our sample (and sub-samples) that we identify by the DFITS-statistic. As suggested by Belsley et al. (1980), we use a cutoff-value $|D F I T S|_{i h j}>2 \sqrt{k / N}$ with $k$, the degrees of freedom (plus 1), and $N$, the number of observations. As a robustness check, we estimate the same models as in Table 10 but use an alternative method of controlling for outliers. We drop all observations for which the absolute and relative difference in the business outcome variables and their lagged terms fall above the 99th percentile. Again, we see a positive correlation between family finance and the business outcome variables for credit-constrained but not for credit-unconstrained firms (table not reported).
} 
correlation between lagged profit and capital stock is positive and significant for creditconstrained and unconstrained firms. Similarly, the coefficient on the household asset index is positive and significant in all specifications. Whereas credit-constrained firms have to finance investments from retained profits, unconstrained firms should be indifferent between internal and external finance. Hence, we would expect the coefficient on profit and assets to turn out insignificant for the unconstrained sample.

Table 10: Family finance and credit constraints

\begin{tabular}{|c|c|c|c|c|c|c|}
\hline & \multicolumn{3}{|c|}{ Constrained } & \multicolumn{3}{|c|}{ Unconstrained } \\
\hline & $\begin{array}{l}\text { Capital } \\
\text { stock }\end{array}$ & $\begin{array}{c}\text { Capital- } \\
\text { output } \\
\text { ratio }\end{array}$ & $\begin{array}{c}\text { Capital- } \\
\text { labour } \\
\text { ratio }\end{array}$ & Capital stock & $\begin{array}{l}\text { Capital-output } \\
\text { ratio }\end{array}$ & $\begin{array}{c}\text { Capital- } \\
\text { labour ratio }\end{array}$ \\
\hline $\begin{array}{l}\text { Family } \\
\text { finance }\end{array}$ & $\begin{array}{l}0.260^{* *} \\
(0.115)\end{array}$ & $\begin{array}{l}0.226^{*} \\
(0.119)\end{array}$ & $\begin{array}{l}0.259^{* *} \\
(0.107)\end{array}$ & $\begin{array}{l}-0.064 \\
(0.111)\end{array}$ & $\begin{array}{c}0.028 \\
(0.108)\end{array}$ & $\begin{array}{c}0.077 \\
(0.108)\end{array}$ \\
\hline $\begin{array}{l}\text { Family } \\
\text { Labour }\end{array}$ & $\begin{array}{c}0.422^{*} \\
(0.247)\end{array}$ & $\begin{array}{c}0.174 \\
(0.244)\end{array}$ & $\begin{array}{l}-0.504^{* *} \\
(0.246)\end{array}$ & $\begin{array}{l}0.733^{* *} \\
(0.299)\end{array}$ & $\begin{array}{c}0.415 \\
(0.307)\end{array}$ & $\begin{array}{l}-0.046 \\
(0.313)\end{array}$ \\
\hline $\begin{array}{l}\text { Primary } \\
\text { education }\end{array}$ & $\begin{array}{c}0.371^{*} \\
(0.190)\end{array}$ & $\begin{array}{l}-0.010 \\
(0.213)\end{array}$ & $\begin{array}{l}0.325^{*} \\
(0.195)\end{array}$ & $\begin{array}{c}0.315 \\
(0.278)\end{array}$ & $\begin{array}{l}0.574^{* * * *} \\
(0.199)\end{array}$ & $\begin{array}{c}0.128 \\
(0.236)\end{array}$ \\
\hline $\begin{array}{l}\text { Secondary } \\
\text { education } \\
\text { (O-Level) }\end{array}$ & $\begin{array}{l}0.801^{* * * *} \\
(0.192)\end{array}$ & $\begin{array}{l}0.397^{*} \\
(0.219)\end{array}$ & $\begin{array}{l}0.737^{* * * *} \\
(0.189)\end{array}$ & $\begin{array}{l}0.656^{* *} \\
(0.268)\end{array}$ & $\begin{array}{l}0.628^{* * *} \\
(0.190)\end{array}$ & $\begin{array}{l}0.515^{* *} \\
(0.220)\end{array}$ \\
\hline $\begin{array}{l}\text { Secondary } \\
\text { education } \\
\text { (A-Level) }\end{array}$ & $\begin{array}{l}0.913^{* * *} \\
(0.216)\end{array}$ & $\begin{array}{c}0.685^{* * *} \\
(0.244)\end{array}$ & $\begin{array}{c}0.893^{* * * *} \\
(0.207)\end{array}$ & $\begin{array}{c}0.759^{* * * *} \\
(0.283)\end{array}$ & $\begin{array}{c}0.806^{* * * *} \\
(0.210)\end{array}$ & $\begin{array}{l}0.525^{* *} \\
(0.234)\end{array}$ \\
\hline Firm age & $\begin{array}{l}-0.014 \\
(0.011)\end{array}$ & $\begin{array}{l}-0.023^{*} \\
(0.011)\end{array}$ & $\begin{array}{c}-0.033^{* * *} \\
(0.011)\end{array}$ & $\begin{array}{l}0.016^{* *} \\
(0.007)\end{array}$ & $\begin{array}{l}-0.001 \\
(0.011)\end{array}$ & $\begin{array}{c}0.011^{*} \\
(0.006)\end{array}$ \\
\hline \multirow{2}{*}{$\begin{array}{l}\text { Firm age } \\
\text { squared }\end{array}$} & 0.000 & $0.000^{*}$ & $0.001^{* * * *}$ & $-0.000^{* *}$ & 0.000 & -0.000 \\
\hline & $(0.000)$ & $(0.000)$ & $(0.000)$ & $(0.000)$ & $(0.000)$ & $(0.000)$ \\
\hline $\begin{array}{l}\text { Lagged } \\
\text { asset } \\
\text { index }\end{array}$ & $\begin{array}{l}0.721^{\text {**** }} \\
(0.080)\end{array}$ & $\begin{array}{c}0.266^{* * * *} \\
(0.081)\end{array}$ & $\begin{array}{l}0.527^{* * * *} \\
(0.074)\end{array}$ & $\begin{array}{l}0.401^{* * *} \\
(0.069)\end{array}$ & $\begin{array}{l}0.173^{* * *} \\
(0.059)\end{array}$ & $\begin{array}{c}0.252^{* * *} \\
(0.063)\end{array}$ \\
\hline $\begin{array}{l}\text { Lagged } \\
\text { monthly } \\
\text { profits }\end{array}$ & $\begin{array}{l}0.138^{* * * *} \\
(0.030)\end{array}$ & $\begin{array}{l}-0.049^{* * *} \\
(0.024)\end{array}$ & $\begin{array}{c}0.089^{* * * *} \\
(0.024)\end{array}$ & $\begin{array}{c}0.208^{* * *} \\
(0.032)\end{array}$ & $\begin{array}{c}0.016 \\
(0.025)\end{array}$ & $\begin{array}{c}0.086^{* * *} \\
(0.022)\end{array}$ \\
\hline $\mathrm{N}$ & 374 & 375 & 376 & 394 & 392 & 394 \\
\hline $\mathrm{R}^{2}$ & 0.457 & 0.244 & 0.435 & 0.448 & 0.153 & 0.335 \\
\hline
\end{tabular}

Notes: Robust standard errors in parentheses. The reference category for the education variables is "no education'. Controls for sectors and years are included. ${ }^{*} p<0.10,{ }^{* *} p<0.05,{ }^{* * *} p<0.01$

For both credit-constrained and unconstrained firms, the coefficient of the share of family labour is positive and significant in the case of capital stock, possibly suggesting some complementarities between labour and capital. Yet, the share of family labour is negatively and significantly correlated with the capital-labour ratio for credit-constrained firms. On average, a 
1 per cent increase in the share of family labour leads to a 0.5 per cent decrease in the capitallabour ratio. To validate this finding, we have replaced the share of family labour in total labour with a dummy equal to one if the firm employs any family member. Moreover, we added total labour hours and a dummy indicating whether the entrepreneur is an own account worker as controls. The coefficient on family labour remained negative and significant for the constrained but not for the unconstrained sample (table not reported).

Taken together, these results suggest important allocative inefficiencies. Access to production factors significantly determine how much a firm will invest. This is in obvious contrast to the neoclassical model where the allocation of capital is guided entirely by its marginal product in alternative uses. From the empirical literature, we know that creditconstrained firms operate with suboptimal capital stocks and therefore their capital-labour ratios are probably already too low. If an increased use of family labour is correlated with further diminishing capital-labour ratios this indicates even higher efficiency losses. However, using a different definition of capital stock that excludes the value of inventories affects the estimates considerably. Access to family finance and the share of family labour are not significant for the constrained entrepreneurs anymore.

As expected, the level of education of the entrepreneur is positively correlated with all three business outcome variables. The coefficients for firm age and its squared term are only significant for the unconstrained sample. Thus, we do not find evidence of capital accumulation through retained profits among credit-constrained firms. Unconstrained entrepreneurs seem to accumulate capital over time until they reach their optimal stock.

We can confirm the findings depicted in Table 10 when dropping all entrepreneurs who state they have no demand for a formal loan from the unconstrained sample. The coefficients on family finance remain insignificant for entrepreneurs who received formal loans for all three dependent variables (Table A.4 in the Appendix). As before, the coefficient on family labour is negative and significant for the constrained group but negative and insignificant for both the narrowly defined unconstrained and the no demand group in the regressions with capital-labour ratio as dependent variable. However, the sample size drops to 88 observations for the unconstrained sample, which is why these results should be interpreted with caution.

Including only a binary variable indicating whether the firm was established with startup money from the family instead of the combined family finance variable (start-up finance and/or family loan) gives similar results as described above (table not reported). When using a binary variable equal to one if the entrepreneur has a family loan, we see a positive correlation 
between this variable and business outcomes for credit-unconstrained firms. However, only $3 \%$ of entrepreneurs have a family loan.

There are several potential biases associated with the regression results presented above. First, there is reason to believe that the regressors are correlated with the error term. Unobserved owner and firm characteristics, such as entrepreneurial ability, may determine the capital stock and are not adequately captured by the independent variables included in our model. A BreuschPagan Lagrange multiplier test rejects the null hypothesis that there are no significant differences across units and hence, pooled OLS is inappropriate. As we have panel data, we would usually estimate the above specifications using fixed or random effects. However, our variable of interest, access to family finance, shows no variation over time and thus, would be absorbed by the intercept when using fixed effects. Yet, a Hausman test indicates that using random effects is also inappropriate since it rejects the null hypothesis that the individual error terms are uncorrelated with the independent variables.

Another key concern is the simultaneity of credit demand and supply, which jointly determine credit constraints. Estimating a causal relationship would require an exogenous determinant of credit supply. Yet, we partition the sample based on the endogenous criterion of whether the entrepreneur is credit-constrained or not. Credit constraints are likely to be determined by omitted variables that simultaneously influence other independent variables. For instance, entrepreneurial ability will affect access to formal credit. At the same time, ability might be positively correlated with wealth, as more able individuals are likely to be in a better position to accumulate wealth through other means than entrepreneurial activity. In addition, more able entrepreneurs may be capable of managing larger enterprises and therefore find it easier to accumulate capital. In terms of differences in accumulation paths between enterprises that are credit-constrained and those that are not, these biases should lead us to observe (even) higher average capital stocks for firms that are not constrained.

To alleviate this endogeneity problem, we intended to use exogenous variation in family size as an instrument for informal credit supply. The data contain information about the number of living parents, siblings, cousins and cross-cousins. These kinship variables are significant predictors of the probability and the amount of financial assistance given and received by the entrepreneur (results not shown here). However, there seems to be no correlation between the number of living family members and our family finance variable. Table 11 shows the first stage of a two-stage least squares estimation (2SLS) regression using the kinship variables for the sample of credit-constrained entrepreneurs. 
Table 11: First-stage regression (2SLS) using kinship variables

\begin{tabular}{lc}
\hline \hline & Access to family finance \\
\hline Number of parents (+ in-laws) living outside the entrepreneur's hh & 0.009 \\
& $(0.177)$ \\
Number of parents (+ in-laws) living inside the entrepreneur's hh & 0.016 \\
Entrepreneur has 1-3 siblings & $(0.030)$ \\
& -0.051 \\
Entrepreneur has 4-7 siblings & $(0.120)$ \\
& -0.162 \\
Entrepreneur has 8 or more siblings & $(0.122)$ \\
Entrepreneur has 1-3 cousins & -0.185 \\
& $(0.138)$ \\
Entrepreneur has 4-7 cousins & -0.093 \\
Entrepreneur has 8-13 cousins & $(0.111)$ \\
$\mathrm{R}^{2}$ & 0.089 \\
\hline Entrepreneur has 14 or more cousins & $(0.112)$ \\
\hline
\end{tabular}

Notes: Standard errors in parentheses. The reference categories for the kinship variables are no siblings and no cousins, respectively. Firm and entrepreneur characteristics, sector and year dummies are included. ${ }^{*} p<0.10,{ }^{* *}$ $p<0.05,{ }^{* * *} p<0.01$

Thus, variables measuring family size do not seem to be appropriate instruments for access to family finance. It may be the quality rather than the quantity of the kin network that affects business outcomes.

While we are not aware of suitable instruments to alleviate this endogeneity problem, we use alternative definitions of credit constraints for sensitivity analysis. First, we use household wealth as a proxy for access to financial resources (Cabral \& Mata, 2003; Evans \& Jovanovic, 1989). We construct the 1-year lag of wealth quartiles using a standardized wealth index from principal component analysis and compare entrepreneurs from households in the first with those from households in the fourth wealth quartile. Otherwise, the specifications remain the same as above. We can largely confirm the patterns of Table 10. In Table 12, we see that family finance is positively and significantly correlated with the capital stock and capital- 
output ratio for entrepreneurs in the first asset quartile but not for entrepreneurs in the fourth asset quartile.

Table 12: Family finance and asset groups

\begin{tabular}{|c|c|c|c|c|c|c|}
\hline & \multicolumn{3}{|c|}{ Asset quartile 1} & \multicolumn{3}{|c|}{ Asset quartile 4} \\
\hline & $\begin{array}{l}\text { Capital } \\
\text { stock }\end{array}$ & $\begin{array}{c}\text { Capital- } \\
\text { output ratio }\end{array}$ & $\begin{array}{c}\text { Capital- } \\
\text { labour ratio }\end{array}$ & $\begin{array}{l}\text { Capital } \\
\text { stock }\end{array}$ & $\begin{array}{c}\text { Capital- } \\
\text { output ratio }\end{array}$ & $\begin{array}{c}\text { Capital- } \\
\text { labour } \\
\text { ratio }\end{array}$ \\
\hline Family finance & $\begin{array}{l}0.304^{*} \\
(0.174)\end{array}$ & $\begin{array}{l}0.382^{* *} \\
(0.170)\end{array}$ & $\begin{array}{c}0.173 \\
(0.162)\end{array}$ & $\begin{array}{l}-0.162 \\
(0.180)\end{array}$ & $\begin{array}{c}0.026 \\
(0.153)\end{array}$ & $\begin{array}{c}0.133 \\
(0.162)\end{array}$ \\
\hline Family labour & $\begin{array}{c}1.107^{* * *} \\
(0.376)\end{array}$ & $\begin{array}{c}0.188 \\
(0.386)\end{array}$ & $\begin{array}{l}-0.075 \\
(0.390)\end{array}$ & $\begin{array}{c}0.555 \\
(0.507)\end{array}$ & $\begin{array}{l}1.286^{* *} \\
(0.517)\end{array}$ & $\begin{array}{l}-0.474 \\
(0.417)\end{array}$ \\
\hline $\begin{array}{l}\text { Primary } \\
\text { education }\end{array}$ & $\begin{array}{c}0.640^{* * *} \\
(0.237)\end{array}$ & $\begin{array}{c}0.277 \\
(0.222)\end{array}$ & $\begin{array}{l}0.520^{* *} \\
(0.235)\end{array}$ & $\begin{array}{c}0.185 \\
(0.263)\end{array}$ & $\begin{array}{c}0.000 \\
(.)\end{array}$ & $\begin{array}{l}-0.189 \\
(0.219)\end{array}$ \\
\hline $\begin{array}{l}\text { Secondary } \\
\text { education } \\
\text { (O-Level) }\end{array}$ & $\begin{array}{l}1.285^{* * *} \\
(0.242)\end{array}$ & $\begin{array}{l}0.424^{*} \\
(0.238)\end{array}$ & $\begin{array}{c}0.791^{\text {**** }} \\
(0.237)\end{array}$ & $\begin{array}{c}0.000 \\
(.)\end{array}$ & $\begin{array}{c}0.299 \\
(0.226)\end{array}$ & $\begin{array}{c}0.000 \\
(.)\end{array}$ \\
\hline $\begin{array}{l}\text { Secondary } \\
\text { Education } \\
\text { (A-Level) }\end{array}$ & $\begin{array}{l}1.636^{* * *} \\
(0.284)\end{array}$ & $\begin{array}{l}1.456^{* * * *} \\
(0.292)\end{array}$ & $\begin{array}{l}1.025^{* * *} \\
(0.260)\end{array}$ & $\begin{array}{c}0.213 \\
(0.198)\end{array}$ & $\begin{array}{l}0.416^{*} \\
(0.217)\end{array}$ & $\begin{array}{l}-0.066 \\
(0.165)\end{array}$ \\
\hline Firm age & $\begin{array}{c}0.002 \\
(0.020)\end{array}$ & $\begin{array}{l}-0.000 \\
(0.018)\end{array}$ & $\begin{array}{l}-0.003 \\
(0.020)\end{array}$ & $\begin{array}{c}0.036^{* * *} \\
(0.011)\end{array}$ & $\begin{array}{c}0.009 \\
(0.010)\end{array}$ & $\begin{array}{c}0.025^{* * *} \\
(0.009)\end{array}$ \\
\hline $\begin{array}{l}\text { Firm age } \\
\text { squared }\end{array}$ & $\begin{array}{l}-0.000 \\
(0.000)\end{array}$ & $\begin{array}{c}0.000 \\
(0.000)\end{array}$ & $\begin{array}{c}0.000 \\
(0.000)\end{array}$ & $\begin{array}{c}-0.000^{* * * *} \\
(0.000)\end{array}$ & $\begin{array}{l}-0.000 \\
(0.000)\end{array}$ & $\begin{array}{c}-0.000^{* * *} \\
(0.000)\end{array}$ \\
\hline $\begin{array}{l}\text { Lagged } \\
\text { monthly profits }\end{array}$ & $\begin{array}{c}0.254^{* * *} \\
(0.055)\end{array}$ & $\begin{array}{c}0.038 \\
(0.028)\end{array}$ & $\begin{array}{c}0.166^{* * *} \\
(0.040)\end{array}$ & $\begin{array}{c}0.210^{* * *} \\
(0.039)\end{array}$ & $\begin{array}{l}-0.059^{*} \\
(0.032)\end{array}$ & $\begin{array}{c}0.043 \\
(0.028)\end{array}$ \\
\hline $\mathrm{N}$ & 188 & 192 & 189 & 180 & 178 & 176 \\
\hline $\mathrm{R}^{2}$ & 0.403 & 0.237 & 0.345 & 0.363 & 0.210 & 0.295 \\
\hline
\end{tabular}

Notes: Robust standard errors in parentheses. The reference category for the education variables is 'no education'. Controls for sectors and years are included. ${ }^{*} p<0.10,{ }^{* *} p<0.05,{ }^{* * *} p<0.01$

Further, we expect that formal firms, which are defined as those that are registered with the tax authority, face lower barriers to obtaining formal credit than informally operating firms. Hence, we divide the sample into informal and formal firms to check robustness. Again, we can confirm the findings of Table 10. In Table 13, we see that family finance is positively and highly significantly correlated with all three business outcome variables for informal firms but not for formal firms. 
Table 13: Family finance and formality

\begin{tabular}{|c|c|c|c|c|c|c|}
\hline & \multicolumn{3}{|c|}{ Informal } & \multicolumn{3}{|c|}{ Formal } \\
\hline & $\begin{array}{l}\text { Capital } \\
\text { stock }\end{array}$ & $\begin{array}{c}\text { Capital- } \\
\text { output } \\
\text { ratio }\end{array}$ & $\begin{array}{c}\text { Capital- } \\
\text { labour } \\
\text { ratio }\end{array}$ & $\begin{array}{l}\text { Capital } \\
\text { stock }\end{array}$ & $\begin{array}{c}\text { Capital- } \\
\text { output } \\
\text { ratio }\end{array}$ & $\begin{array}{c}\text { Capital- } \\
\text { labour ratio }\end{array}$ \\
\hline Family finance & $\begin{array}{c}0.225^{* * *} \\
(0.085)\end{array}$ & $\begin{array}{c}0.241^{* * * *} \\
(0.086)\end{array}$ & $\begin{array}{c}0.230^{* * * *} \\
(0.082)\end{array}$ & $\begin{array}{l}-0.039 \\
(0.162)\end{array}$ & $\begin{array}{c}-0.152 \\
(0.188)\end{array}$ & $\begin{array}{c}0.149 \\
(0.182)\end{array}$ \\
\hline Family labour & $\begin{array}{c}0.692^{* * * *} \\
(0.194)\end{array}$ & $\begin{array}{c}0.051 \\
(0.204)\end{array}$ & $\begin{array}{l}-0.315 \\
(0.197)\end{array}$ & $\begin{array}{l}-0.121 \\
(0.541)\end{array}$ & $\begin{array}{c}0.635 \\
(0.537)\end{array}$ & $\begin{array}{l}-0.237 \\
(0.551)\end{array}$ \\
\hline $\begin{array}{l}\text { Primary } \\
\text { education }\end{array}$ & $\begin{array}{c}0.320^{*} \\
(0.164)\end{array}$ & $\begin{array}{c}0.134 \\
(0.172)\end{array}$ & $\begin{array}{c}0.108 \\
(0.165)\end{array}$ & $\begin{array}{c}0.000 \\
(.)\end{array}$ & $\begin{array}{c}0.000 \\
(.)\end{array}$ & $\begin{array}{l}-0.306 \\
(0.262)\end{array}$ \\
\hline $\begin{array}{l}\text { Secondary } \\
\text { education } \\
\text { (O-Level) }\end{array}$ & $\begin{array}{c}0.710^{* * * *} \\
(0.160)\end{array}$ & $\begin{array}{l}0.306^{*} \\
(0.172)\end{array}$ & $\begin{array}{c}0.483^{* * *} \\
(0.161)\end{array}$ & $\begin{array}{l}0.570^{* * *} \\
(0.260)\end{array}$ & $\begin{array}{c}0.137 \\
(0.293)\end{array}$ & $\begin{array}{l}-0.062 \\
(0.203)\end{array}$ \\
\hline $\begin{array}{l}\text { Secondary } \\
\text { education } \\
\text { (A-Level) }\end{array}$ & $\begin{array}{c}1.044^{* * *} \\
(0.174)\end{array}$ & $\begin{array}{c}0.672^{* * * *} \\
(0.192)\end{array}$ & $\begin{array}{c}0.702^{* * * *} \\
(0.174)\end{array}$ & $\begin{array}{c}0.544^{*} \\
(0.285)\end{array}$ & $\begin{array}{c}0.235 \\
(0.313)\end{array}$ & $\begin{array}{c}0.000 \\
(.)\end{array}$ \\
\hline Firm age & $\begin{array}{c}-0.026^{* * *} \\
(0.009)\end{array}$ & $\begin{array}{c}-0.014^{* * *} \\
(0.007)\end{array}$ & $\begin{array}{c}-0.027^{* * * *} \\
(0.009)\end{array}$ & $\begin{array}{c}0.013 \\
(0.014)\end{array}$ & $\begin{array}{c}0.002 \\
(0.016)\end{array}$ & $\begin{array}{l}0.027^{* *} \\
(0.013)\end{array}$ \\
\hline $\begin{array}{l}\text { Firm age } \\
\text { squared }\end{array}$ & $\begin{array}{c}0.000^{* * * *} \\
(0.000)\end{array}$ & $\begin{array}{l}0.000^{* * *} \\
(0.000)\end{array}$ & $\begin{array}{c}0.000^{* * * *} \\
(0.000)\end{array}$ & $\begin{array}{l}-0.000 \\
(0.000)\end{array}$ & $\begin{array}{l}-0.000 \\
(0.000)\end{array}$ & $\begin{array}{c}-0.000^{* * *} \\
(0.000)\end{array}$ \\
\hline $\begin{array}{l}\text { Lagged } \\
\text { asset index }\end{array}$ & $\begin{array}{c}0.433^{* * *} \\
(0.059)\end{array}$ & $\begin{array}{c}0.221^{* * * *} \\
(0.055)\end{array}$ & $\begin{array}{c}0.377^{* * *} \\
(0.056)\end{array}$ & $\begin{array}{c}0.404^{* * * *} \\
(0.089)\end{array}$ & $\begin{array}{c}0.032 \\
(0.081)\end{array}$ & $\begin{array}{l}-0.000 \\
(0.093)\end{array}$ \\
\hline $\begin{array}{l}\text { Lagged } \\
\text { monthly } \\
\text { profit }\end{array}$ & $\begin{array}{c}0.147^{* * *} \\
(0.021)\end{array}$ & $\begin{array}{l}-0.023 \\
(0.018)\end{array}$ & $\begin{array}{c}0.090^{* * * *} \\
(0.019)\end{array}$ & $\begin{array}{l}0.153^{* * * *} \\
(0.030)\end{array}$ & $\begin{array}{c}0.020 \\
(0.041)\end{array}$ & $\begin{array}{l}0.073^{* *} \\
(0.037)\end{array}$ \\
\hline $\mathrm{N}$ & 605 & 606 & 611 & 167 & 167 & 169 \\
\hline $\mathrm{R}^{2}$ & 0.382 & 0.199 & 0.334 & 0.425 & 0.151 & 0.219 \\
\hline
\end{tabular}

Notes: Robust standard errors in parentheses. The reference category for the education variables is 'no education'. Controls for sectors and years are included. ${ }^{*} p<0.10,{ }^{* *} p<0.05,{ }^{* * * *} p<0.01$

Finally, we rely on the subjective assessment of entrepreneurs to identify credit-constrained firms. We construct a dummy variable which is equal to 1 if the entrepreneur confirms that lack of finance has constrained the performance of his/her business in the past. With this measure of credit constraints, we cannot confirm our previous findings. The correlation between access to family finance and the business outcome variables is stronger and more significant for entrepreneurs who state that lack of finance does not constrain their business than for those who confirm that lack of finance is a problem (table not reported).

Table 14 shows the pairwise correlations between the different proxies for credit constraints. Correlations between the first three measures are highly significant with coefficients between 14 and 21 per cent. Credit-constrained entrepreneurs are likely to be in the lowest asset quartile and to operate an informal firm. Likewise, entrepreneurs in the lowest asset 
quartile are likely to operate an informal firm. Although mostly significant, the correlation coefficients of perceived credit constraints and the other measures are much smaller suggesting that self-perception does not reflect objective credit constraints.

Table 14: Correlation matrix for measures of credit constraints

\begin{tabular}{lcccc}
\hline \hline & $\begin{array}{c}\text { Constrained } \\
\text { (as defined in Figure 3) }\end{array}$ & $\begin{array}{c}\text { Asset } \\
\text { quartile 1 }\end{array}$ & Informal & $\begin{array}{c}\text { Self- } \\
\text { perception }\end{array}$ \\
\hline $\begin{array}{l}\text { Constrained } \\
\text { (as defined in Figure 3) }\end{array}$ & 1.0000 & & & \\
Asset quartile 1 & 0.1500 & 1.0000 & & \\
& $(0.0000)$ & & & \\
& 0.1418 & 0.2172 & 1.0000 & \\
Informal & $(0.0000)$ & $(0.0000)$ & & \\
& & & & \\
Self-perception & 0.0981 & 0.0445 & 0.0736 & 1.0000 \\
& $(0.0004)$ & $(0.1035)$ & $(0.0078)$ & \\
\hline
\end{tabular}

Notes: Standard errors in parentheses.

We visualize the development of capital stock, capital-output ratio and capital-labour ratio over time using nonparametric regressions in Figure 4, Figure 5 and Figure 6. For this, the logarithm of each measure is regressed on a full set of sector dummies. We then use local polynomial smoothing based on an Epanechnikov kernel to plot the residual of this regression plus the mean value against firm age ${ }^{12}$. We distinguish between firms that are credit-constrained and do not have access to family finance, firms that are credit-constrained with access to family finance and credit-unconstrained firms. Credit-constrained firms without access to family finance start out with the lowest level of capital stock, capital-output ratio and capital-labour ratio. All three measures increase with firm age but never catch up to the level of firms in the other two categories. Still, this suggests that firms are able to accumulate capital over time despite binding credit constraints. Credit-constrained firms older than 10 years seem to decrease their stock and use of capital again. The level of capital stock, capital-output ratio and capital-labour ratio is remarkably similar between firms with either access to informal or formal credit. Creditconstrained firms act the most dynamic in adapting their capital stock and factor inputs over time. In contrast, all three outcome variables show little adjustment over time for the unconstrained sample. This may indicate that unconstrained entrepreneurs are able to start close to their optimal capital stock and factor inputs and thus reach their steady state outcomes quickly.

\footnotetext{
${ }^{12}$ More precisely, we use the number of years the firm has been run by the entrepreneur. This measure can be different from firm age, if an established firm was taken over by an entrepreneur. We only include firms that have been run up to 14 years by an entrepreneur.
} 
Yet, we cannot exclude the possibility that the increase in capital stock of creditconstrained entrepreneurs may in part be driven by selective firm mortality. If firms with suboptimal capital stocks are more likely to exit and thus drop out of our sample, the increase of capital with firm age may simply be the result of selective firm exit.

Figure 4: Capital stock and firm age
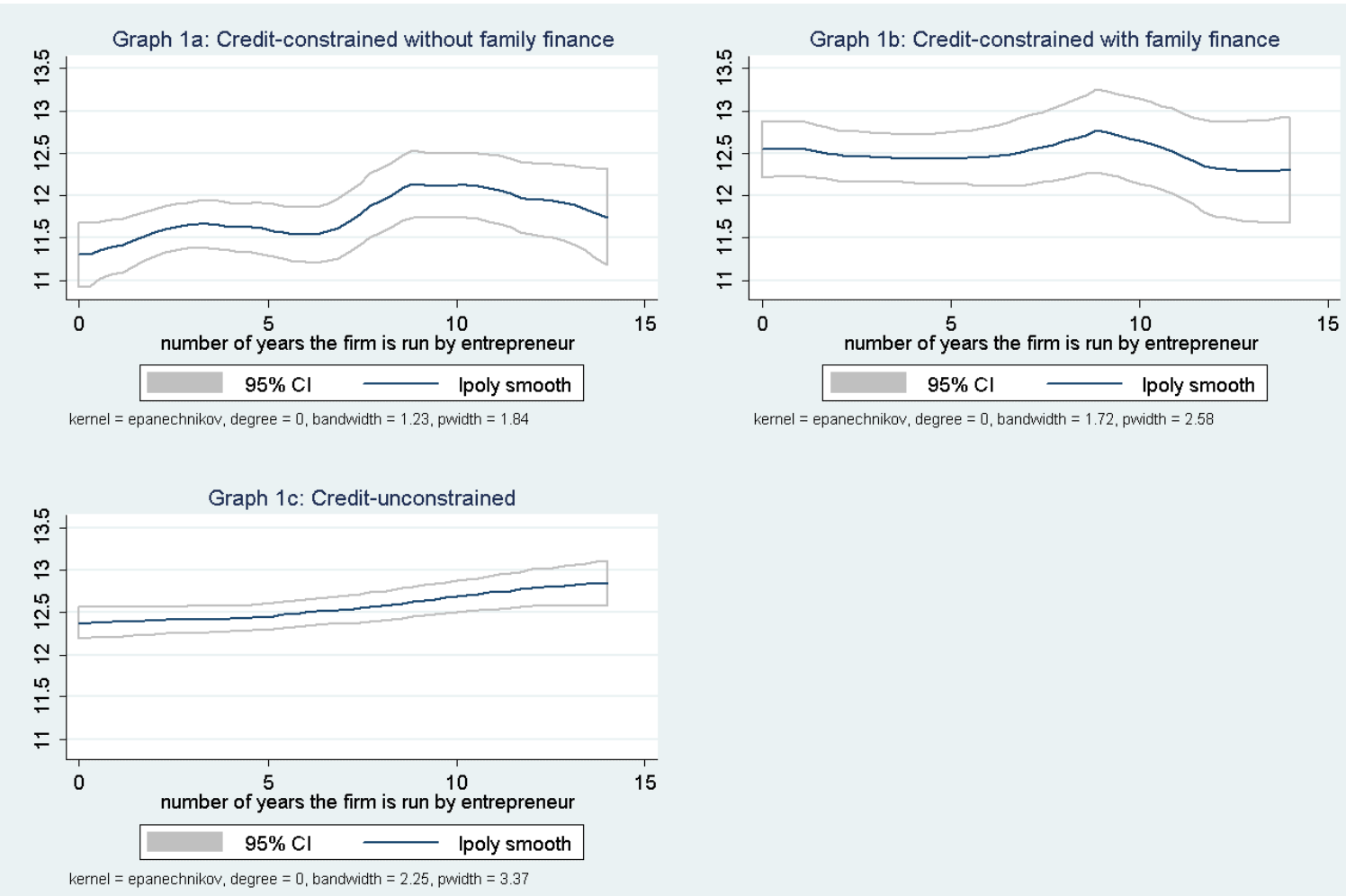

With increasing capital stock, credit-constrained firms use more capital in the production process. Yet, they still show the lowest capital intensity of production. At the same time, they seem to use capital more efficiently. Thus, efficiency losses would be reduced if capital could be shifted from unconstrained to credit-constrained firms. 
Figure 5: Capital-output ratio and firm age
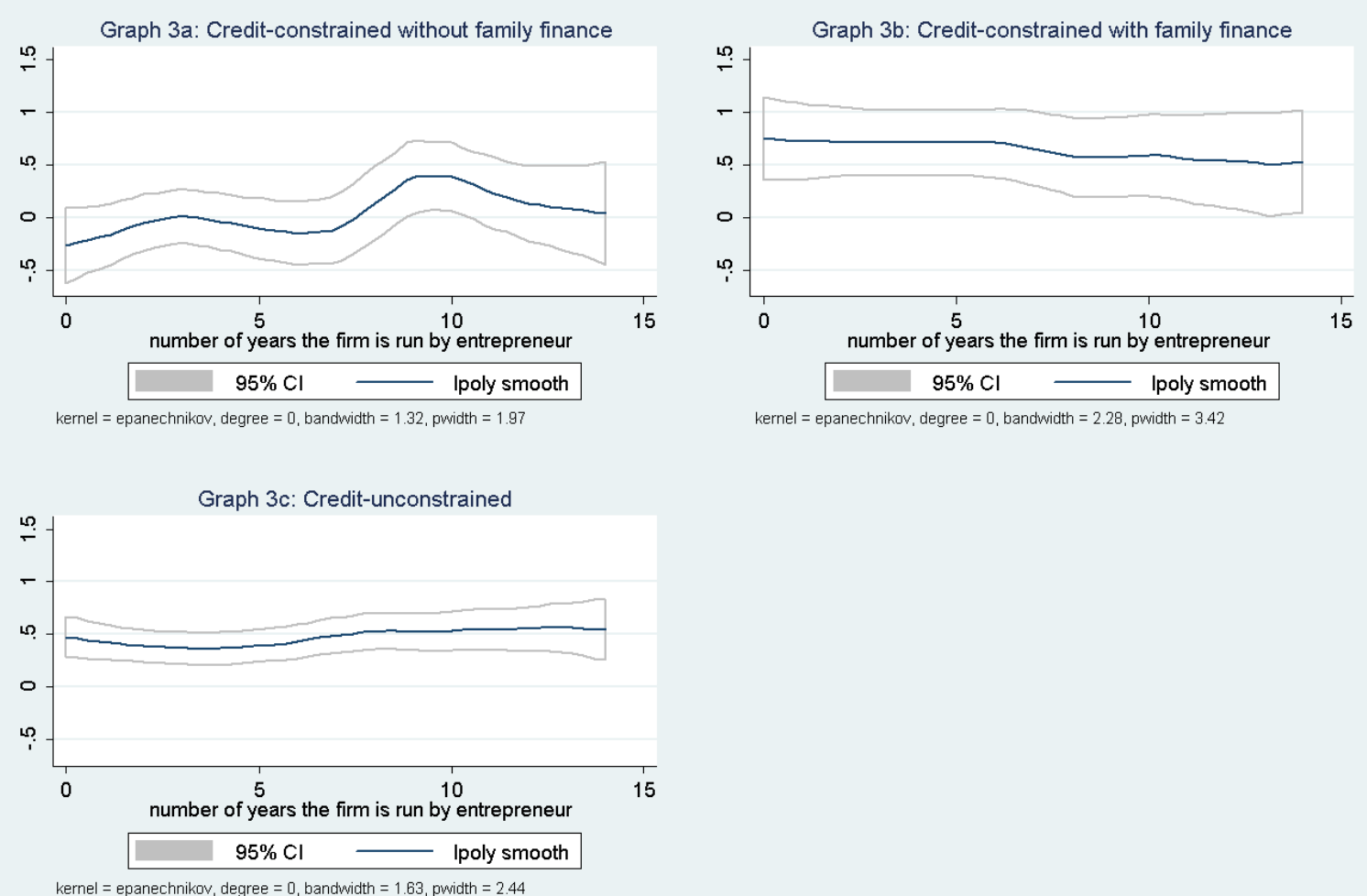

Figure 6: Capital-labour ratio and firm age
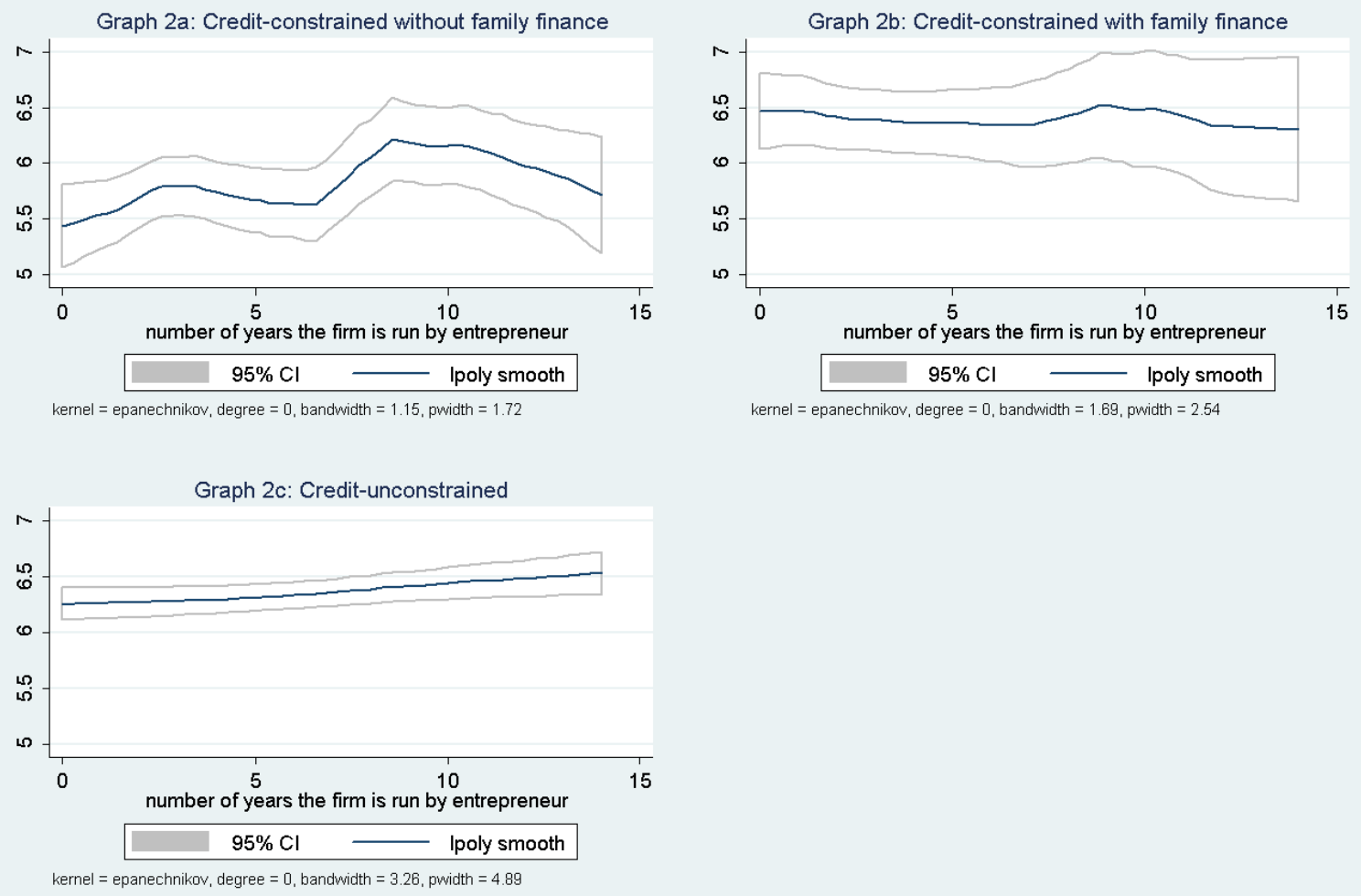


\subsection{Conclusion}

We show for the case of Sri Lankan small-scale entrepreneurs that having access to finance from the social network strongly and significantly increases the level of capital stock and the capital intensity of production. Moreover, this positive effect only holds formally creditconstrained entrepreneurs. We hence present empirical evidence for the positive effect of social capital on access to credit. Further, we visualize the development of capital stock and capital intensity of production over time for three groups of firms: those that are credit-constrained without access to family finance, those that are credit-constrained and have access to family finance, and formally credit-unconstrained firms. We find that firms with access to informal finance fare remarkably similar to firms with access to formal finance while firms without access to either formal or informal finance never catch up to the level of capital stock or capital intensity of firms in the other two groups.

The implication of our findings, however, cannot be to strengthen social capital so that it can act as a substitute to the formal credit market. This would lead to an exclusion problem of all those who cannot rely on their social network to help equip them with finance. The fact that firms without access to formal and informal finance operate with much lower capital stocks and do not manage to catch up to firms with access to finance over time underlines this point. Moreover, there may be a problem of reversed causality, namely that credit-constrained firms cannot invest as much in social capital formation as credit-unconstrained firms. Hence, they stay credit-constrained. This is shown by Shoji et al. (2012) for the case of Sri Lanka.

In a perfectly functioning credit market, social capital would not be needed to obtain credit. Those entrepreneurs in our study who are formally credit-unconstrained can be regarded as the benchmark case. For them, family finance does not have any effect on capital stock or capital intensity of production. Consequently, policy should be directed towards strengthening the formal credit market and improving access to credit for small, informally operating entrepreneurs or for those with little collateral. 


\title{
CHAPTER 5
}

\section{Firm performance and workers' wages: Evidence from micro enterprises in Uganda}

\author{
Natascha Haitz and Sarah Wiegel
}

\begin{abstract}
Micro and small enterprises (MSEs) provide income and employment for a large share of the population in developing countries. Yet, many people working in MSEs earn less than the living wage. This paper analyses whether workers in micro enterprises benefit from higher profitability of firms using longitudinal matched employer-employee data on Ugandan micro enterprises and all their workers.

Firm characteristics are found to play an important role in the determination of wages. This is inconsistent with a perfectly competitive labour market. A 1 per cent increase in hourly profits ceteris paribus increases wages by 0.218 per cent. This finding is robust to changes in the profit measure, different estimation methods and samples. Three different explanations for the observed profit-wage relationship are explored: rent sharing, risk sharing and efficiency wage models. We find no evidence for rent sharing using the educational difference between employer and worker as a measure for bargaining power. The profit-wage relationship seems to be stronger for firms experiencing high profit risk - indicating risk sharing - albeit the effect is very small. Finally, our results show that larger firms pay higher wages - consistent with efficiency wage models - but this effect does not seem to work through profits.
\end{abstract}

Acknowledgements: We thank the Volkswagen foundation and the Lower Saxony Ministry for Science and Culture for research funding through the "Volkswagen Vorab" programme. In addition, the authors gratefully acknowledge funding by the Federal Ministry for Economic Cooperation and Development (BMZ) within the framework of the project "Employment, Empowerment and Living Standards", implemented in cooperation with the German Development Bank (KfW). The authors thank Jann Lay and participants of the internal GIGA seminar for helpful comments. 


\subsection{Introduction}

Micro and small enterprises account for a large share of economic activity and employment in lower- and middle-income countries. In Ghana, firms with fewer than 10 workers provide 57 per cent (60 per cent) of employment in the manufacturing (services) sector. In Ethiopia, these figures are well above 90 per cent (World Bank, 2012). Yet, most MSEs are not able to provide productive employment and a decent livelihood for their owners and workers (ILO, 2019b). Based on household surveys from 18 developing countries, Banerjee and Duflo (2011) found that 44 per cent of urban dwellers working in a non-agricultural business live on less than US \$ 1 a day. So far, many policies targeting MSEs aimed at promoting firm growth, but little is known on determinants of wages and whether workers benefit from the intended higher growth (and profits) of these firms. A better understanding of the economics of wage setting and subsequent wage movements is crucial to alleviate working poverty.

This paper examines the effect of firm performance (i.e. profits) on wages using longitudinal matched employer-employee data on Ugandan micro enterprises and all their workers. We first test for the existence of firm wage differentials between equally skilled workers. We find that firm-fixed effects alone account for 47 per cent of the explained variation in wages in our sample. Next, we focus on the effect of firm profits and find a robust correlation between profits and workers' wages. This result is set into context to three distinct theories of the profit wage relation: rent sharing, risk sharing and efficiency wages. The analysis finds no evidence of rent sharing or the payment of efficiency wages. Firms facing high profit risk pay higher wages, but the effect is very small. The inconclusive results regarding the channels of the profit-wage relation reflect the difficulties in operationalizing these mechanisms empirically and the large measurement error inherent in MSE data from developing countries.

With its' particularly dynamic urban informal sector, growing at an annual rate of over 10 per cent, Uganda provides a suitable framework for analysing micro and small enterprises. The sector is comprised of over 800,000 micro enterprises, employing approximately 3 million people, which is 90 per cent of the non-agricultural, private sector workforce (Republic of Uganda, 2010). Almost half of the people being employed in MSEs are wageworkers. The majority of people working in MSEs earn less than the living wage ${ }^{13}$ (Besamusca \& Tijdens, 2012).

\footnotetext{
13 The Living Wage is an approximate income needed to meet a family's basic needs including food, housing, transport, health, education, tax deductions and other necessities. The monthly net living wage for a single adult in 2018 was 376,700629,800 UGX (Int. \$ 146-244) and 771,053-1,235,368 UGX (Int. \$ 299-479) for a typical Ugandan family (WageIndicator.org, 2018).
} 
The paper is structured as follows: The subsequent chapter presents the theoretical framework and reviews the relevant literature on wage differentials and the profit wage relation. Chapter 5.3 introduces the dataset, explains variable definitions and provides the reader with summary statistics. Then, chapter 5.4 describes the empirical strategy while chapter 5.5 presents the main empirical findings as well as their robustness. Finally, chapter 5.6 concludes with final remarks about the relevance of the results for policy-making and future research.

\subsection{Literature review}

\subsubsection{The profit-wage relation}

In a perfectly competitive labour market, supply and demand for each type of worker result in a single wage rate (i.e. price) paid to all employees with the same set of characteristics (Martins, 2007). In this setting, firms take market wages as given and heterogeneity of firms influences which workers are hired, but not the wage level of any particular worker. The main driver of wage differentials between workers is hence the market-level skill price and wages reflect skills rather than anything else (Acemoglu \& Autor, 2011; Goldin \& Katz, 2009; Katz \& Autor, 1999).

This is at odds with the vast empirical literature presenting evidence for inter- as well as intra-industry wage differentials among workers with similar qualities (e.g. Krueger and Summers, 1986; Groshen, 1991; Abowd, Kramarz and Margolis, 1999 for developed countries; and Taira, 1966; Gatica, Mizala and Romaguera, 1995 for low- and middle-income countries), indicating that firm level factors are indeed not negligible in determining workers' wages. Abowd et al. (1999) use longitudinal matched employer-employee data for France to estimate a wage regression that includes both worker- and firm-fixed effects. They find that firm-fixed effects account for about 20 per cent of the wage dispersion. This result has been confirmed in subsequent studies using the same methodology for a set of different countries (Abowd \& Kramarz, 2004; Abowd et al., 2002). The existence of wage differentials among workers with similar characteristics is consistent with imperfectly competitive labour market models.

One dimension of firm-wage differences across workers that has attracted particular interest is the relationship between firm profitability and wages. Recent studies that focus on firm-specific productivity shocks and control for the non-random sorting of workers to more or less productive firms typically find that a 10 per cent increase in value added per worker leads to an increase in wages of 0.5 to 1.5 per cent (Arai, 2003; Card et al., 2018; Cardoso \& Portela, 2009). The positive correlation between firm profits and workers' wages has also been found in labour markets in developing economies(Arbache, 2001; Bigsten et al., 2003; Teal, 1996; 
Velenchik, 1997). Yet, these studies almost exclusively focus on large, formal (manufacturing) firms. To the best of our knowledge, there is no empirical evidence on the relation between firm profits and workers' wages and the related transmission channels for micro and small enterprises in developing countries.

At the same time, there is reason to believe that wage setting in large firms is not comparable to that in micro enterprises. First, MSEs have fundamentally different characteristics than large firms. Second, many labour market institutions (e.g. minimum wages, unions, social security benefits) may not apply to (informal) MSEs. Therefore, we test whether the empirical findings presented above can be replicated with a sample of micro enterprises in a developing country context.

Proposition 1: Firm wage differentials exist between equally skilled workers.

Proposition 2: Profits have a significantly positive effect on workers' wages.

Moreover, the channels through which profits may affect wages in MSEs in developing countries are largely unexplored. The literature identifies three mechanisms through which firm profits may affect workers' wages: (i) rent sharing, (ii) risk sharing and (iii) efficiency wages.

\subsubsection{Rent sharing}

Rent sharing is referring to a situation in which rents (= profits after paying all production factors at their market rates) are shared by the firm, at least in some part, with the workers of that firm (Martins, 2007). Wages result from a bargaining process between employer and employees. This generates a long-run positive relation between wages and profits. Given that workers have bargaining power and are able to punish "unfair" employers, they might perceive it fair to receive wage gains following productivity improvement (Kar \& Datta, 2015).

The following bargaining model by Blanchflower et al. (1996) describes an optimization problem in which both employer and employees try to maximize their outcome:

$$
\max \phi \log \{[u(w)-u(\bar{w})] n\}+(1-\phi) \log \pi
$$

$\phi$ is the bargaining power of employees, $u(w)$ is the workers utility from wage $w, \bar{w}$ is the outside option. $n$ is employment (and, by the choice of units, also the probability of employment) and $\pi$ profits, which are defined as the following concave revenue function:

$$
\pi=f(n)-w n
$$

It is assumed that in case bargaining fails, the firm earns zero profit and the workers receive $\overline{\mathrm{w}}$. Solving equation (5) for an interior optimum results in: 


$$
w \cong \bar{w}+\left(\frac{\phi}{1-\phi}\right) \frac{\pi}{n}
$$

$\frac{\phi}{1-\phi}$ is the workers relative bargaining power. The equilibrium wage is determined by the reservation wage $\bar{w}$, the relative bargaining power of the employer and the employee, and the level of profit per employee. Since the firm will loose $\frac{\pi}{n}$ if bargaining fails, it is optimal for the employer to share some part of the profit in order to let the employee increase his or her wage over the wage of the outside option.

Proposition 3: The positive effect of profit on wages significantly increases with greater bargaining power of the workers.

While unions, minimum wages and unemployment benefits (factors that increase the workers' relative bargaining power) are mainly observed in industrialized countries, social norms may influence bargaining power both in developed as well as in developing countries. If workers can easily observe firm profits, social norms regarding solidarity could force the entrepreneur to share the enterprise rents with his or her workers (Grimm et al., 2013). Yet, kinship networks could also play a role in providing help during unemployment.

Plenty of evidence for rent sharing is found in developed countries (e.g. Arai, 2003; Blanchflower et al., 1996; Hicks, 1935; Hildreth \& Oswald, 1997). Research on developing countries is rare. Teal (1996) finds strong effects from profitability (as a potential source of rents) on earnings for firms in the Ghanaian manufacturing sector. He uses a drop in the exchange rate to proxy profit shocks exogenous to the firm. His results imply that moving from the 10th to the 90th percentile of the firm profit distribution increases workers' earnings by 58 per cent. Velenchik (1997) finds that value added per worker, sales per worker and profits per worker are all positively correlated with earnings in a sample of Zimbabwean manufacturing firms. By contrast, Martins and Esteves (2006) find no evidence of rent sharing for a sample of formal manufacturing firms in Brazil, using macroeconomic shocks as exogenous variation in profits.

\subsubsection{Risk sharing}

In the presence of risk and uncertain output, labour contracts can be used to efficiently distribute the risk between the employer and the employee by specifying the appropriate wage scheme (Gutierrez, 2013). Under risk sharing, changes in value added are absorbed by the firm and the workers when the firm is exposed to shocks, so that profits and wages change in the same 
direction. In this way, workers provide insurance to their employers. Workers accept the volatility in wages in exchange for a wage premium and higher job security.

The following model based on Blanchflower et al. (1996) poses a maximization problem in which employees and employers share the risk of demand shocks:

$$
\int v(\pi) g(\mu) d \mu
$$

Equation (8) represents the expected utility of the firm. $v(\pi)$ is a concave function, indicating that the firm's utility depends on profits. $g(\mu)$ is the probability density function of demand shocks. Equation (8) is maximized subject to:

$$
\begin{gathered}
\int[n u(w)+(1-n) u(b)] g(\mu) d \mu \geq \bar{u} \\
\pi \equiv \mu f(n)-w n
\end{gathered}
$$

where $u(w)$ is the utility of the worker when employed and $u(b)$ when unemployed, whereas the probability of being employed is $n$ and that of being unemployed is $1-n$. Therefore, workers maximize their expected utility derived from either wages $u(w)$ or from unemployment benefits $u(b)$. The model assumes that employers have to supply at least a market level of expected utility $\bar{u}$. For simplicity, the production function only depends on labour. The solution of the maximization problem is a wage function $w(\mu)$ defined on demand shocks. The key first order conditions are:

$$
\begin{gathered}
w(\mu):-v^{\prime}(\pi)+\lambda u^{\prime}(w) \stackrel{!}{=} 0 \\
n(\mu): v^{\prime}(\pi)\left[\mu f^{\prime}(n)-w\right]+\lambda[u(w)-u(b)] \stackrel{!}{=} 0
\end{gathered}
$$

Differentiating equation (11) results in

$$
\frac{d w}{d \pi}=\frac{v^{\prime \prime}(\pi)}{\lambda u^{\prime \prime}(w)}
$$

This function is strictly positive if both the employer and the employee are strictly risk averse, hence profits and wages will move together. It is often assumed that employers are risk-neutral (e.g. Gutierrez, 2013) due to better access to financial markets. In this case, the optimal contract would result in a constant wage. If the employee is risk neutral, the function is undefined.

Assume that the employer's relative risk aversion is $\Omega$ while the employee's relative risk aversion is $r$. After combining (10) and (12), this results in

$$
\frac{d w}{d \pi} \frac{\pi}{w}=\frac{\Omega}{r}
$$


The elasticity of wages with respect to profits therefore equals the ratio of the employer's relative risk aversion to the worker's relative risk aversion.

Proposition 4.1: The positive effect of profit on wages significantly increases with the employer's risk aversion (holding the employee's risk aversion constant).

Proposition 4.2: The positive effect of profit on wages significantly increases with the level of risk the firm is exposed to.

As Baily (1974) and Cardoso and Portela (2009) argue, there are alternatives to risk sharing. Financial markets could, for instance, provide an opportunity for firms to diversify their risk and act as a credit and insurance facility, rather than workers. Fakhfakh and FitzRoy (2004) emphasize the importance of inventories and liquid assets, while Bigsten et al. (2003a) mention networks as an opportunity for risk sharing. Gutierrez (2013) states the importance of a welldiversified portfolio, the firms' size and product diversification as determinants of wages under risk. All these factors are likely to influence the risk aversion $\Omega$ and hence the elasticity of wages with respect to profits.

In the case of Uganda, formal insurance or formal credit markets are often not accessible for micro entrepreneurs. At the same time, firms in developing countries in general and (informal) micro enterprises in particular are exposed to high risk (due to unreliable infrastructure, poor contract enforcement, lack of legal protection, etc.). High risk and weak financial markets let risk sharing appear very plausible in this specific setting.

Using panel data for four African countries, Bigsten et al. (2003b) find that firms, when hit by temporary shocks, cushion the effect on profits by risk sharing with their workers. They examine rent and risk sharing in one model, by creating a measure for long-term shocks (indicating rent sharing) and short-term shocks (indicating risk sharing). The authors find only evidence for risk sharing.

\subsubsection{Efficiency wages}

A third theory that suggests that wages and profit are correlated is the payment of efficiency wages. Efficiency wages refer to wages paid above the market-clearing level of productivity in a competitive market (Shapiro \& Stiglitz, 1984). If worker productivity depends positively on wages, firms may find it profitable to pay efficiency wages. In contrast to the rent and risk sharing theories, the causal relationship between wages and profit in the efficiency wage theory runs from higher wages to higher productivity and hence profit. Several conceptually distinct mechanisms have been put forward in the literature to explain the payment of efficiency wages. 
A first model of efficiency wages postulates that they are paid in order to minimize turnover costs (Salop, 1979). If firms must bear part of the costs of turnover and if turnover is a decreasing function of the wages firms pay, there may be an incentive to raise wages in order to minimize turnover costs (Krueger and Summers, 1988).

A second mechanism presumes that efficiency wages are paid to raise workers' effort level under imperfect information (Shapiro \& Stiglitz, 1984). In a competitive labour market, a rise in the real wage of workers will lower the aggregate demand for labour. This creates an unemployment pressure leading to a lowered incidence of shirking at the workplace. Therefore, without increasing internal monitoring costs or implementing punishments, firms can extract higher productivity from their workers. Workers being fired due to shirking will find it more difficult to regain employment than before the wages were raised, given the lower demand for workers under these circumstances. Wage dispersion for identical workers arises in both models because of firm-specific differences in the cost of turnover, the cost of monitoring and the cost of employee shirking.

A third theory is based on selection rather than incentive efforts. If workers are heterogeneous in ability and if ability and reservation wages are positively correlated, firms that offer higher wages will attract higher-quality job applicants (Katz, 1986).

Lastly, firms may pay efficiency wages to improve workers' morale and loyalty to their firm (Akerlof, 1982). Improved morale and loyalty, in turn, may have a direct, positive effect on workers' productivity. In Akerlof's partial gift exchange model, the firm can succeed in raising group work norms and average effort by paying workers a gift of wages in excess of the reservation wage, in return for their gift of higher effort.

Solow (1979) shows in a simple model how increased wages directly affect productivity through an increase in worker effort. Assuming labour is the only production factor, identical, perfectly competitive firms aim at profit maximization:

$$
\pi=Y-w L
$$

where $Y$ is the firm's output, $w$ the wage it pays and $L$ the amount of labour it hires. Firm's output is not only a function of the number of workers, but also their effort.

$$
Y=F(e L), \quad F^{\prime}(\cdot)>0 \quad F^{\prime \prime}(\cdot)<0
$$

Wage is the only determinant of effort.

$$
e=e(w), \quad e^{\prime}(\cdot)>0
$$

We assume there are $L$ identical workers. Every worker supplies one unit of labour inelastically. The problem of the firm may then be rewritten as 


$$
\max _{L, w} F(e(w) L-w L
$$

Unconstrained firms chose $L$ and $w$ according to the first-order conditions:

$$
\begin{gathered}
F^{\prime}(e(w) L) e(w)-w=0 \\
F^{\prime}(e(w) L) L e^{\prime}(w)-L=0
\end{gathered}
$$

We can rewrite equation (19) as:

$$
F^{\prime}(e(w) L)=\frac{w}{e(w)}
$$

Substituting equation (21) into equation (20), and dividing by $L$ yields:

$$
\frac{e^{\prime}\left(w^{*}\right) w^{*}}{e\left(w^{*}\right)}=1
$$

The optimal wage $w^{*}$ satisfies the condition that the elasticity of effort with respect to the wage is unity (Solow condition). The wage $w^{*}$ is known as the efficiency wage since it minimizes wage costs per efficiency unit of labour. Because here $e$ (and thus $\left.e^{\prime}\left(w^{*}\right)\right)$ only depends on $w$, equation (22) implies that all firms pay the same wage. Inter-firm wage differentials exist if firms face different costs of turnover and supervision ${ }^{14}$.

The efficiency wage theories presented above are additive. Firms may pay noncompetitive wages with the intention to reduce shirking and turnover, to attract a high-quality labour force and to increase workers' feeling of loyalty. When looking at efficiency wages from the view of implicit contract theory, there is a trade-off between risk sharing and the payment of efficiency wages. Asymmetric information and moral hazard (and hence the offering of efficiency wages) set a limit to the use of labour contracts as a risk sharing instrument. A labour contract that fully (or even partly) insures the worker against risk may reduce the workers incentives to exert effort at work.

The more employees the firm has, the more difficult is it to monitor each of them. Hence, efficiency wages are expected to increase in firm size. Thus, the literature frequently uses firm size and the ratio of supervisor to employees as controls to test for efficiency wages. For instance, Oi and Idson (1999) find that the organization of work tasks and the selection of workers (whose productivity is not always observable) are responsible for the positive relation between wages and firm size.

Velenchik (1997) examines different explanations for the wage premium associated with working for larger firms in the Zimbabwean manufacturing sector. The results support the

\footnotetext{
${ }^{14}$ As can be shown in a more general model of efficiency wages, where supervision matters for workers' effort (Fafchamps \& Söderbom, 2006).
} 
idea that larger firms may use higher wages to increase the quality of their applicant pools, to reduce employee turnover, and to enhance worker loyalty. Evidence for efficiency wages is also found by Arbache (2001), Esteves (2006) and Menezes and Raposo (2014) for the case of Brazil. Fafchamps and Söderbom (2006) conclude that larger firms in nine SSA countries and Morocco pay a wage premium to motivate their workers to exert effort and initiative.

Proposition 5: The positive effect of profit on wages significantly increases in firm size.

\subsection{Data}

The analysis uses a matched employer-employee dataset on micro and small enterprises in Kampala, Uganda, For the purpose of our analysis we constrict the sample to micro enterprises (enterprises with five or less regular workers). This definition only considers regular workers, therefore firm size can, for a small number of cases, exceed five workers if firms hire several casual workers, apprentices or non-paid workers. Fifty-one per cent of our sampled micro enterprises are own-account workers and therefore not included in the analysis.

Data were collected in Kampala, Uganda, in nine survey waves from 2012 to 2018. The sampling strategy followed a two-stage procedure. In a first step, 16 out of 220 geographical business zones of Kampala were randomly selected in 2012. Since many businesses are informal and an official list of businesses does not exist, the sample population was created by going from business to business and collecting basic information about the business. In a second step, out of this sample population, a sample of 450 (500 for 2015-2018) firms was randomly drawn. Firms that dropped out over the years were replaced with firms in the same industry and district if possible.

While firms have a unique identification code, this is not the case for workers. Hence, they could not be tracked over time. This yields a firm panel, with the corresponding information on workers coming in the shape of a repeated cross-section. Reported data cover the firm and all workers engaged in the firm, whether regular worker, casual worker, unpaid family member or business partner. As the analysis focusses on the determinants of workers' wages, non-paid employees and business partners (who receive a share of the firm's profit rather than a fixed wage) are excluded from the analysis.

The questionnaire covers firm characteristics and performance measures, personal characteristics and attitudes as well as the household composition of the entrepreneur. Table 15, Table 16 and Table 17 show the summary statistics of the key variables for the sample of observations described above. Education is the only worker characteristic for which we have 
information for all waves. Information on the age and tenure of the worker is only available for 2012; information on the workers' gender and contract type is available for 2012, 2013 and 2014. Information on the days worked per week of each worker is missing in 2012. Since this information is needed to calculate an hourly wage, the year 2012 is not included in the regression analysis. However, since some information on the employees is only available in 2012, descriptive statistics on workers depicted in Table 17 include data from the 2012 wave.

Most firms (33.6 per cent) are in the 'Manufacturing (remaining)' industry. Wages are highest in the 'Manufacture of printing/paper products and related services' industry with a median hourly wage of UGX 887 and lowest in the 'Retail electric, phones, household appliances and related services' industry (UGX 526 median hourly wage). The printing industry is also the sector with the by far largest capital stock and highest reported profits (UGX 1,322,000 per month), while the 'Hair dressing and beauty' and the 'manufacture of textile/wearing apparel industry' has the lowest average self-reported profit (UGX 394,000 and UGX 389,000, respectively). The distributions of profits, value added, and capital stock are heavily skewed. Median values are much smaller than the respective means. In terms of monthly hours worked, the industries do not differ largely with an average of 500 total working hours per month. Regarding firm size and firm age, the 'Manufacturing (remaining)' industry stands out with an average of 14.25 years in operation and 3.1 workers per firm.

When looking at worker characteristics (Table 17), one can see that 85 per cent of the workers are regular employees, 12 per cent are casual employees while the remaining 2 per cent are apprentices. More than half of the workers have completed secondary education, while 34 per cent only have completed primary education. Seventy-seven per cent of the workers are not related to the entrepreneur. The remaining 23 per cent are direct or extended family members. Thirty per cent of the employees are female (with only 23 per cent of the entrepreneurs being female). Most workers have only an oral (54 per cent) or even no contract (41 per cent). Average tenure is 2 to 5 years while the average worker age is 19-25. Compared to the workers, education of entrepreneurs is more dispersed with about 40 per cent of entrepreneurs having no or only primary education, 43 per cent having completed secondary and 15 per cent having completed tertiary education. 


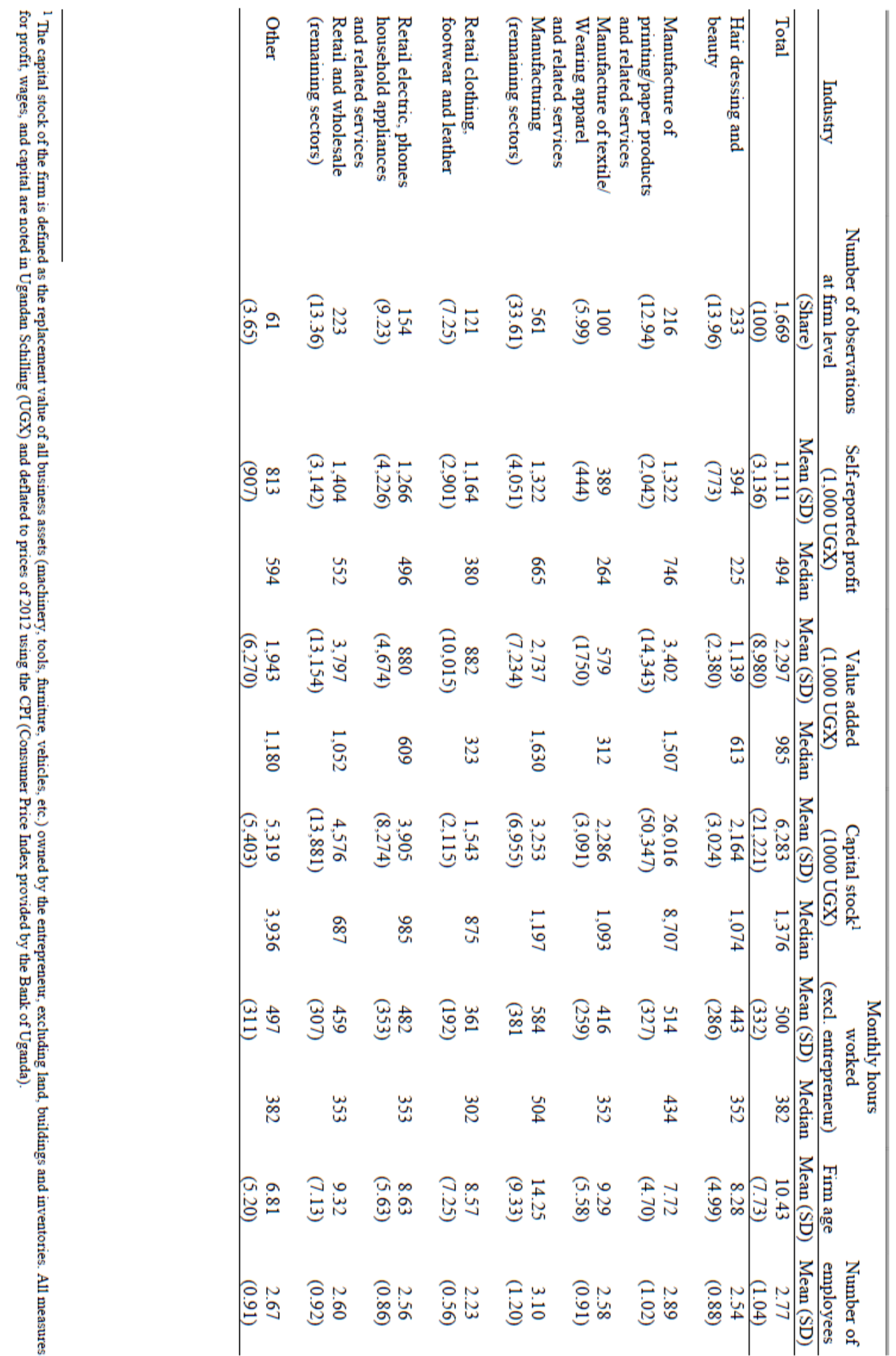


Table 16: Wages by industry

\begin{tabular}{lcc}
\hline \hline & $\begin{array}{c}\text { Mean } \\
\text { (SD) }\end{array}$ & Median \\
\hline All industries & $\begin{array}{c}1,197.35 \\
(2,719.09)\end{array}$ & 711.16 \\
\hline Hair dressing and beauty & $1,200.78$ & 555.95 \\
& $(3,053.47)$ & \\
Manufacture of printing and paper products & $1,291.81$ & 886.93 \\
and related services & $(1,825.01)$ & \\
Manufacture of textile/wearing apparel & 782.42 & \\
and related services & $(907.35)$ & 650.65 \\
& & \\
Manufacturing (remaining sectors) & $1,260.34$ & 807.16 \\
& $(1,990.54)$ & \\
Retail clothing, footwear and leather & 590.61 & 547.82 \\
& $(343.63)$ & \\
Retail electric phones, household appliances & 743.30 & 526.04 \\
and related services & $(920.96)$ & \\
Retail and wholesale (remaining sectors) & $1,767.67$ & 577.70 \\
Other & $(5,844.72)$ & \\
\hline Number of observations & 673.50 & 558.77 \\
\hline
\end{tabular}

Table 17: Worker and entrepreneur characteristics

\begin{tabular}{lcc}
\hline \hline Worker status - Total & $\begin{array}{c}\text { Number of } \\
\text { observations }\end{array}$ & Percentage \\
\hline Employee/ worker regular & $\mathbf{2 , 9 5 0}$ & $\mathbf{1 0 0}$ \\
Employee/ worker casual & 2,519 & 85.39 \\
Apprentice & 370 & 12.54 \\
\hline Relationship to entrepreneur - Total & 61 & 2.07 \\
Non-family member & $\mathbf{2 , 3 8 1}$ & $\mathbf{1 0 0}$ \\
Direct family (siblings, parents) & 1,844 & 77.45 \\
Extended family (cousins, relatives) & 263 & 11.05 \\
\hline Gender of the employees - Total ${ }^{1}$ & 274 & 11.51 \\
Male & $\mathbf{8 1 7}$ & $\mathbf{1 0 0}$ \\
Female & 570 & 69.77 \\
\hline
\end{tabular}

\footnotetext{
${ }^{1}$ Information on the workers' gender and contract type is only available for 2013 and 2014 (2012 not shown).
} 


\begin{tabular}{lcc} 
Contract type - Total & $\mathbf{8 1 6}$ & $\mathbf{1 0 0}$ \\
No contract & 339 & 41.54 \\
Written contract & 32 & 3.92 \\
Oral contract & 445 & 54.53 \\
\hline Workers' tenure - Total ${ }^{2}$ & $\mathbf{3 5 1}$ & $\mathbf{1 0 0}$ \\
0 years & 35 & 9.97 \\
1 year & 108 & 40.74 \\
2-5 years & 159 & 45.30 \\
6-10 years & 42 & 11.96 \\
> 10 years & 7 & 1.99 \\
\hline Age of the employee - Total & $\mathbf{3 7 1}$ & $\mathbf{1 0 0}$ \\
14-18 & 18 & 4.85 \\
19-25 & 180 & 48.52 \\
26-30 & 124 & 33.42 \\
31-54 & 49 & 13.21 \\
\hline Worker education - Total & $\mathbf{2 , 2 4 1}$ & $\mathbf{1 0 0}$ \\
No education & 87 & 3.88 \\
Primary education & 759 & 33.87 \\
Secondary education (O-Level, A-Level) & 1,198 & 53.46 \\
Tertiary education (university) & 197 & 8.79 \\
\hline Entrepreneurs' education - Total & $\mathbf{3 , 0 0 4}$ & $\mathbf{1 0 0}$ \\
No education & 408.58 \\
Primary education & 840 & 27.96 \\
Tertiary education (university) & 30.78 \\
Other & & 14.68 \\
\hline \hline & & 1.00 \\
\hline
\end{tabular}

\subsection{Estimation Model}

When analysing the relationship between firm profits and workers' wages a methodological challenge arises from the multilevel structure of the data. Multilevel data structures exist when some units of analysis are considered as subsets of other units, while data for both units are available. In our data, there are two levels of analysis, the worker level (level 1) and the firm level (level 2), with workers being nested into firms. When estimating multilevel data, one has to account for variance in the dependent variable that is measured at the lowest level of analysis while considering information from the higher level of analysis as well. Ignoring the multilevel

\footnotetext{
${ }^{2}$ Information on the workers' tenure and the age of the employer is only available for 2012.
} 
data structure creates both conceptual and statistical problems. If the contextual levels, i.e. firms, are dropped, the arenas for wage determination are ignored. Aggregating the data to the firm level and ignoring the individual level opens for the ecological fallacy". Through "naive pooling" (Burton et al., 1998) and thereby ignoring the multilevel data structure, it appears as if all individuals are independent observations. However, in this context, error terms are likely to be correlated in a nested way. First, worker observations are not independently distributed among and within firms. Similar workers might be hired into the same firms and therefore build homogenous clusters. Second, workers could be commonly affected by unobserved firm effects. Third, it is very likely that a large share of workers is employed in the same firm for multiple waves, leading to correlated worker observations within firms over time. These problems may lead to incorrect standard errors, inflated Type 1 error rates and biased parameter estimates (Peugh, 2010).

Therefore, we estimate the multilevel model using the estimated dependent variable (EDV) approach (Hanushek, 1974; Lewis \& Linzer, 2005). This is a two-stage approach: In the first step, a separate model for individuals nested within each level 2 unit is estimated. In the second step, the estimates obtained in the first step are used as the dependent variable to be explained by a set of aggregate predictors. That is, first, individual wages are regressed on workers' human capital and a firm-fixed effect. The estimated firm-level fixed effect is an unambiguous measure of the firm-specific wage premium, which is then regressed on firm characteristics to explain differences in firm wage policies (Cardoso, 2000).

The first-stage model looks as follows:

$$
w_{i j t}=\beta_{1} I_{i j t}+F E_{j t}+\varphi_{i j t}+\varepsilon_{i j t}
$$

where the dependent variable $w_{i j t}$ is the individual wage of worker $i$ in firm $j$ at time $t, I_{i j t}$ is a vector of controls for worker productivity, $\varphi_{i j t}$ is unobserved worker heterogeneity, $\varepsilon_{i j t}$ is the error term, $F E_{j t}$ is a firm-fixed effect allowed to vary over time. By using firm- and timefixed effects, we eliminate bias from unobservables that change over time but are constant over firms and unobservable factors that differ across firms but are constant over time. The estimated firm-time-fixed effect $F E_{j t}$ is used as dependent variable $\widehat{w}_{j t}$ in the stage 2 model, given by

$$
\widehat{\mathrm{w}}_{\mathrm{jt}}=\beta_{0}+\beta_{1} \mathrm{~F}_{\mathrm{jt}}+\beta_{2} \pi_{\mathrm{jt}}+\mathrm{y}_{\mathrm{t}}+\mathrm{e}_{\mathrm{jt}}
$$

where $\widehat{w}_{j t}$ is the estimated dependent variable representing the firm wage premium, $F_{j t}$ is a vector of firm controls (capital intensity, firm age, firm size, the entrepreneurs' education,

\footnotetext{
${ }^{3}$ Ecological fallacy is referring to the bias stemming from deducing inferences about individuals from the group they belong to (Steenbergen \& Jones, 2002).
} 
industry), $\pi_{j t}$ is the firms' profit per working hour, $y_{t}$ are year dummies and $e_{j t}$ represents the error term.

Since the dependent variable of the stage 2 regression is based on estimates, the regression residual can be thought of as having two components (Lewis \& Linzer, 2005). The first component is the usual random shock that is part of every regression. The second component is the sampling error, which is the difference between the true and the estimated value of the dependent variable. If the sampling variance differs across observations, the second component will be heteroscedastic. The first component, the random shock, however, could well be homoscedastic. When running a simple Ordinary Least Squares (OLS) regression, heteroscedasticity of the second error component is ignored. A weighted least squares regression (WLS), on the other hand, assumes that the entire residual (the first and second component) is heteroscedastic. Both, OLS and WLS are inefficient and might produce inconsistent estimates of the error term. Lewis and Linzer (2005) argue to use a Feasible Generalized Least squares (FGLS) estimator which uses the variance-covariance matrix from the standard errors of the first stage to generate a weight, which can be used to adjust the second stage regression. The weights (adjusted for a panel dimension) are calculated as follows:

$$
\text { weight }_{j t}=\frac{1}{\sqrt{S E \widehat{w_{l j}}{ }^{2}+{\widehat{\sigma_{J t}}}^{2}}}
$$

where $S E \widehat{w_{l j}}$ are the standard errors of the dependent variable from the first stage and $\widehat{\sigma_{J} t}$ is an estimate of the variance of the error term in the second stage that is not due to the sampling error of the dependent variable (ibid.). To account for the special structure of the error term, we estimate the second stage model using OLS with robust standard errors and using FGLS.

The estimation may further be biased due to the possibility of worker sorting, meaning that more productive workers sort into higher paying firms. A correlation between profits and wages would hence rather be driven by productivity differences between workers than by different firm wage policies. As we have panel data for the firm but only repeated crosssectional observations for their employees, it is not possible to control for unobserved heterogeneity in workers across firms. By regressing wages on workers' human capital and a firm-level fixed effect, wages are purged from (some) observed differences between workers (and unobservable differences correlated with them) (Fafchamps \& Söderbom, 2006). Brown and Medoff (2003), Criscuolo (2000), Arai (2003) and Söderbom et al. (2005) examine the relationship between firm size and wages for a variety of countries and conclude that omitting controls for worker heterogeneity yields a bias of relatively moderate magnitude. 


\subsection{Empirical Analysis}

\subsubsection{Firm wage differentials}

Table 18 presents the results of the wage regression estimated with fixed effects.

Table 18: Worker level vs. firm-level wage determinants

\begin{tabular}{|c|c|c|c|c|}
\hline \multirow[t]{2}{*}{ Dependent variable } & \multicolumn{4}{|c|}{ Log of hourly wages } \\
\hline & (I) & (II) & (III) & (IV) \\
\hline No education & $\begin{array}{c}-0.506 * * * \\
(0.134)\end{array}$ & $\begin{array}{c}-0.737 * * * \\
(0.132)\end{array}$ & $\begin{array}{l}-0.0917 \\
(0.130)\end{array}$ & $\begin{array}{l}-0.143 \\
(0.108)\end{array}$ \\
\hline Primary education & $\begin{array}{c}-0.428 * * * \\
(0.0993)\end{array}$ & $\begin{array}{c}-0.643 * * * \\
(0.0960)\end{array}$ & $\begin{array}{c}-0.0814 \\
(0.0937)\end{array}$ & $\begin{array}{c}-0.116 \\
(0.0813)\end{array}$ \\
\hline Secondary education & $\begin{array}{c}-0.330^{* * *} \\
(0.0882)\end{array}$ & $\begin{array}{c}-0.469 * * * \\
(0.0894)\end{array}$ & $\begin{array}{c}-0.0200 \\
(0.0834)\end{array}$ & $\begin{array}{c}-0.0733 \\
(0.0761)\end{array}$ \\
\hline Casual worker & $\begin{array}{c}0.567 * * * \\
(0.0823)\end{array}$ & $\begin{array}{c}0.397 * * * \\
(0.0762)\end{array}$ & $\begin{array}{c}0.337 * * * \\
(0.0817)\end{array}$ & $\begin{array}{l}-0.0767 \\
(0.131)\end{array}$ \\
\hline Apprentice & $\begin{array}{c}-0.818^{* * *} \\
(0.148)\end{array}$ & $\begin{array}{c}-0.859 * * * \\
(0.140)\end{array}$ & $\begin{array}{c}-0.747 * * * \\
(0.181)\end{array}$ & $\begin{array}{c}-0.501 * * \\
(0.229)\end{array}$ \\
\hline Hourly pay & & $\begin{array}{c}2.424 * * * \\
(0.152)\end{array}$ & $\begin{array}{c}2.579 * * * \\
(0.179)\end{array}$ & $\begin{array}{c}2.789 * * * \\
(0.354)\end{array}$ \\
\hline Daily pay & & $\begin{array}{c}0.542 * * * \\
(0.0589)\end{array}$ & $\begin{array}{c}0.563 * * * \\
(0.0813)\end{array}$ & $\begin{array}{c}1.305 * * * \\
(0.217)\end{array}$ \\
\hline Weekly pay & & $\begin{array}{c}0.243^{* *} \\
(0.103)\end{array}$ & $\begin{array}{c}0.191 \\
(0.148)\end{array}$ & $\begin{array}{c}0.797 * * \\
(0.363)\end{array}$ \\
\hline Constant & $\begin{array}{c}6.822 * * * \\
(0.0936)\end{array}$ & $\begin{array}{c}6.598 * * * \\
(0.104)\end{array}$ & $\begin{array}{c}6.148 * * * \\
(0.115)\end{array}$ & $\begin{array}{c}5.902 * * * \\
(0.140)\end{array}$ \\
\hline Time fixed effects & Yes & Yes & Yes & No \\
\hline Firm fixed effects & No & No & Yes & No \\
\hline Firm-time fixed effects & No & No & No & Yes \\
\hline Observations & 2,102 & 2,102 & 2,102 & 1,424 \\
\hline Adjusted R-squared levels & 0.0833 & 0.275 & 0.636 & 0.893 \\
\hline
\end{tabular}

Notes: The baseline category of the worker status variables (casual worker, apprentice) is regular workers. Tertiary education is the baseline category for the worker education variables. Monthly pay is the reference category for the dummies that signal the periodicity of pay. All standard errors (in parenthesis) are clustered at the firm level. R-squared level is the R-squared obtained from the model where the fixed effects are captured by means of dummy variables. Significance levels: *** $\mathrm{p}<0.01, * * \mathrm{p}<0.05, * \mathrm{p}<0.1$

Specification (I) and (II) include wave dummies. In specification (III), we add firm effects to the time effects model to have a time- and firm-fixed effects regression model. Finally, specification (IV) ${ }^{4}$ includes interactions between firm- and wave dummies (firm-time fixed effects). Firm-time fixed effects explain most of the variation in logarithmized hourly wages. Together with the observed characteristics they explain 89 per cent of the variation in the

\footnotetext{
${ }^{4}$ The introduction of firm-time-fixed effects in specification (IV) reduces the number of observations by 678 because singleton groups (firm-year groups with only one observation) are dropped. Maintaining singleton groups in linear regressions where fixed effects are nested within clusters can overstate statistical significance and lead to incorrect inference (Correia, 2015).
} 
dependent variable. The firm-fixed effects alone account for about 40 per cent of the explained variation in wages ${ }^{5}$. That is, time-invariant firm characteristics as well as firm characteristics that vary over time each account for a substantial part of the variation in workers' wages. This result presents first evidence that competitive labour market theory does not apply for micro enterprises in developing countries.

Education and worker status are the only observable worker characteristics for which data are available for all survey periods. In the first and second specification, low education has the expected negative effect on wages. When adding firm-fixed effects to the regression in specification (III) and firm-time fixed effects in specification (IV), education loses its significance and the coefficients' sizes decrease largely. This result may indicate that workers sort into specific firms: while the level of education matters for the determination of wages in general, differences in education within the firm do not affect wages. However, one has to keep in mind that the variation in education and wages within firms is rather low, which might partly be responsible for the results.

In specification (I) to (III), casual workers earn significantly more than regular workers do. Controlling for the periodicity of pay reduces the size of the coefficient (casual workers are more frequently paid on an hourly or daily basis; their wage may reflect more accurately their productive working time than the common monthly pay of regular workers). Introducing firmtime fixed effects renders the coefficient insignificant. Apprentices earn significantly less than regular workers do. Yet, it has to be noted that the number of apprentices is very small in the sample and that the coefficient size could be driven by some other factor correlated with the apprentice status but not caused by it (for example the age of apprentices).

The constant in model (III) shows the average value of the firm-fixed effects (Angrist \& Pischke, 2009). It is highly significant, which indicates an important influence of firms on wages. This finding sets the stage for the next step, which investigates the specific firm characteristics that drive these results and whether firm profits are part of these drivers.

\subsubsection{Profit-wage relation}

In the second stage estimation, the dependent variable is the previously estimated firm-time fixed effect, which is purged of differences in observable worker productivity and unobservable characteristics correlated with them. This fixed effect represents the firm-specific wage premium paid to the employee, gives his or her observable worker characteristics. Table 19 subsequently adds a stricter conditioning on the estimation of the profit-wage relation. In

\footnotetext{
${ }^{5}$ Regressing firm dummies on wages resulted in an adjusted $\mathrm{R}^{2}$ of 0.420 .
} 
column (I), profit is regressed on the wage premium with the capital-labour ratio as only control. Then, in column (II), industry and year controls are added. In columns (III) to (V), further firm controls are added successively: first firm age, then firm size and lastly the entrepreneurs' educational level. Column (V) is the preferred specification. Throughout all specifications, the coefficient of profit remains highly significant. A 1 per cent increase in the hourly profit of a firm increases the average hourly wage ceteris paribus by 0.218 per cent. This is considerably higher than the mean rent sharing elasticities found in the most recent papers for developed countries (Card et al. (2018) estimate a mean profit elasticity of 0.08 per cent).

When looking at the remaining controls in the regression, only some factors seem to have an impact on wages. Capital intensity significantly and positively affects wages. This result is in line with the literature on wage determinants (e.g. Arai, 2003; Fafchamps \& Söderbom, 2006). Arai (2003) provides several explanations for this finding: first, the workers bargaining power for rent extraction is declining with the relative importance of labour costs to capital costs. Entrepreneurs might be less resistant to higher wage demands when labour costs are a minor part of the firms' costs than in cases where the expenses for labour represent the major part of firm costs. Second, a higher capital-labour ratio should raise the marginal productivity of the workers; hence increase turnover costs or costs of poor performance. In line with the efficiency wage theory, entrepreneurs pay wage premia in order to decrease the incidence of these costs. A third explanation is that a higher capital-labour ratio may be an indicator of considerable fixed costs for the firm. This might result in high barriers to entry and hence greater market concentration, which will finally be reflected by product market rents.

The positive effect of firm size on wages can also be explained with the efficiency wage theory. In large firms, problems of incomplete information are more prevalent and supervision is more costly. Therefore, employers pay higher wages to incentivize their workers. Employers with no or secondary education pay lower wages than those with tertiary education. This may reflect the fact that owners with high education run more productive firms. In line with this argumentation, no significant industry wage differentials remain once all firm and employer characteristics are included in the regression. 
Table 19: Firm-level wage determinants (EDV approach using firm-time fixed effects from Table 18)

\begin{tabular}{|c|c|c|c|c|c|}
\hline \multirow[t]{2}{*}{ Dependent variable } & \multicolumn{5}{|c|}{ Hourly wage premium (firm-time fixed effects) } \\
\hline & (I) & (II) & $\begin{array}{c}\text { (III) } \\
\text { Pooled OLS }\end{array}$ & (IV) & $(\mathrm{V})$ \\
\hline Log of hourly profit & $\begin{array}{l}0.228 * * * \\
(0.0330)\end{array}$ & $\begin{array}{l}0.221 * * * \\
(0.0341)\end{array}$ & $\begin{array}{l}0.221 * * * \\
(0.0343)\end{array}$ & $\begin{array}{l}0.219 * * * \\
(0.0336)\end{array}$ & $\begin{array}{l}0.218 * * * \\
(0.0339)\end{array}$ \\
\hline Log of capital labour ratio & $\begin{array}{l}0.104 * * * \\
(0.0200)\end{array}$ & $\begin{array}{l}0.101 * * * \\
(0.0227)\end{array}$ & $\begin{array}{c}0.0977 * * * \\
(0.0229)\end{array}$ & $\begin{array}{c}0.0899 * * * \\
(0.0227)\end{array}$ & $\begin{array}{c}0.0793 * * * \\
(0.0227)\end{array}$ \\
\hline Firm age & & & $\begin{array}{l}0.00895 \\
(0.0128)\end{array}$ & $\begin{array}{l}0.00740 \\
(0.0126)\end{array}$ & $\begin{array}{l}0.00482 \\
(0.0126)\end{array}$ \\
\hline Firm age squared & & & $\begin{array}{l}-0.000143 \\
(0.000346)\end{array}$ & $\begin{array}{l}-0.000145 \\
(0.000339)\end{array}$ & $\begin{array}{l}-5.45 \mathrm{e}-05 \\
(0.000339)\end{array}$ \\
\hline Firm size & & & & $\begin{array}{l}0.135 * * * \\
(0.0338)\end{array}$ & $\begin{array}{l}0.134 * * * \\
(0.0353)\end{array}$ \\
\hline $\begin{array}{l}\text { Education employer: } \\
\text { No education }\end{array}$ & & & & & $\begin{array}{c}-0.340 * * \\
(0.143)\end{array}$ \\
\hline $\begin{array}{l}\text { Education employer: } \\
\text { Completed primary } \\
\text { education }\end{array}$ & & & & & $\begin{array}{l}-0.0545 \\
(0.0998)\end{array}$ \\
\hline $\begin{array}{l}\text { Education employer: } \\
\text { Completed secondary } \\
\text { education }\end{array}$ & & & & & $\begin{array}{c}-0.264 * * * \\
(0.0895)\end{array}$ \\
\hline $\begin{array}{l}\text { Manufacturing of printing/ } \\
\text { paper products }\end{array}$ & & $\begin{array}{l}0.296^{*} \\
(0.159)\end{array}$ & $\begin{array}{l}0.306^{*} \\
(0.159)\end{array}$ & $\begin{array}{l}0.279^{*} \\
(0.158)\end{array}$ & $\begin{array}{c}0.226 \\
(0.157)\end{array}$ \\
\hline $\begin{array}{l}\text { Manufacturing of textile/ } \\
\text { wearing apparel }\end{array}$ & & $\begin{array}{l}0.283 * \\
(0.162)\end{array}$ & $\begin{array}{l}0.295^{*} \\
(0.161)\end{array}$ & $\begin{array}{l}0.283^{*} \\
(0.158)\end{array}$ & $\begin{array}{c}0.171 \\
(0.156)\end{array}$ \\
\hline $\begin{array}{l}\text { Manufacturing } \\
\text { (remaining sectors) }\end{array}$ & & $\begin{array}{l}0.0433 \\
(0.130)\end{array}$ & $\begin{array}{l}0.0174 \\
(0.135)\end{array}$ & $\begin{array}{l}-0.0328 \\
(0.136)\end{array}$ & $\begin{array}{l}-0.0867 \\
(0.139)\end{array}$ \\
\hline $\begin{array}{l}\text { Retail clothing, footwear } \\
\text { and leather }\end{array}$ & & $\begin{array}{c}0.289 \\
(0.200)\end{array}$ & $\begin{array}{l}0.308 \\
(0.199)\end{array}$ & $\begin{array}{c}0.302 \\
(0.203)\end{array}$ & $\begin{array}{l}0.318 \\
(0.211)\end{array}$ \\
\hline $\begin{array}{l}\text { Retail electric, phones, } \\
\text { household appliances }\end{array}$ & & $\begin{array}{c}0.365^{* *} \\
(0.179)\end{array}$ & $\begin{array}{l}0.344^{*} \\
(0.181)\end{array}$ & $\begin{array}{l}0.330^{*} \\
(0.178)\end{array}$ & $\begin{array}{c}0.244 \\
(0.182)\end{array}$ \\
\hline $\begin{array}{l}\text { Retail and wholesale } \\
\text { (remaining sectors) }\end{array}$ & & $\begin{array}{c}0.273 \\
(0.214)\end{array}$ & $\begin{array}{c}0.283 \\
(0.214)\end{array}$ & $\begin{array}{c}0.272 \\
(0.225)\end{array}$ & $\begin{array}{c}0.214 \\
(0.216)\end{array}$ \\
\hline Other & & $\begin{array}{l}-0.0954 \\
(0.169)\end{array}$ & $\begin{array}{l}-0.0980 \\
(0.168)\end{array}$ & $\begin{array}{r}-0.0986 \\
(0.168)\end{array}$ & $\begin{array}{l}-0.148 \\
(0.169)\end{array}$ \\
\hline Constant & $\begin{array}{l}-0.0626 \\
(0.0386)\end{array}$ & $\begin{array}{c}-0.235 \\
(0.148)\end{array}$ & $\begin{array}{l}-0.294 * \\
(0.153)\end{array}$ & $\begin{array}{c}-0.760 * * * \\
(0.203)\end{array}$ & $\begin{array}{c}-0.536 * * \\
(0.229)\end{array}$ \\
\hline Wave dummies & & & Yes & & \\
\hline Observations & 501 & 501 & 500 & 500 & 493 \\
\hline Adjusted R-squared & 0.192 & 0.228 & 0.227 & 0.246 & 0.262 \\
\hline
\end{tabular}

Notes: "Tertiary education" is the baseline category for the entrepreneur education variables. The baseline category for the industry controls is industry 1 ("Hair dressing and beauty"). The baseline category for the year controls is the year 2013. Robust standard errors in parentheses. Significance levels: *** $\mathrm{p}<0.01, * * \mathrm{p}<0.05, * \mathrm{p}<0.1$

To account for the two components of the error term in the estimated dependent variable approach, the model is also estimated using FGLS. The results are very similar to those reported 
in Table 19 (see Appendix, Table B. 1) and emphasize the robustness of the results. Thus, we can conclude that firms do matter in the determination of wages. Profit has a significant effect on workers' wages in our sample of Ugandan SMEs.

We also estimate these regressions using the firm-fixed effect from specification (III) in Table 18. This has the advantage that the estimations are based on a larger sample because firms with only one observation per wave remain in the sample. The results are presented in Table 20. The profit coefficient remains highly significant but reduces in size to 0.144 . We can confirm our earlier results also with regard to the other covariates. The coefficient sizes decrease slightly but their significance remains the same. The only contrasting results are the significant positive coefficients for firm age and firms in the printing and paper products industry. 
Table 20: Firm-level wage determinants (EDV approach using firm-fixed effects from Table 18)

Dependent variable

Log of hourly profit

Log of capital labour ratio

Firm age

Firm age squared

Firm size

(I)

$$
\text { Hourly wage premium (firm fixed effect) }
$$

$\begin{array}{lll}\text { (II) (III) } & \text { (IV) }\end{array}$

Pooled OLS

$\begin{array}{ccccc}0.149 * * * & 0.146 * * * & 0.144 * * * & 0.150 * * * & 0.144 * * * \\ (0.0146) & (0.0149) & (0.0150) & (0.0150) & (0.0150)\end{array}$

$\begin{array}{ccccc}0.0748 * * * & 0.0539 * * * & 0.0499 * * * & 0.0450 * * * & 0.0402 * * * \\ (0.00951) & (0.0109) & (0.0109) & (0.0106) & (0.0107) \\ & & 0.0182 * * * & 0.0141 * * & 0.0131 * * \\ & & (0.00613) & (0.00611) & (0.00609) \\ & & -0.000355 * * & -0.000291 * & -0.000261 \\ & (0.000161) & (0.000161) & (0.000159) \\ & & 0.101 * * * & 0.0988 * * * \\ & & & (0.0172) & (0.0177)\end{array}$

Education employer:

No education

$-0.292 * * *$

(0.0694)

Education employer:

$-0.0122$

Completed primary education

$(0.0546)$

Education employer:

$-0.0827 *$

Completed secondary

education

Manufacturing of printing/

paper products

$\begin{array}{cccc}0.278 * * * & 0.293 * * * & 0.262 * * * & 0.260 * * * \\ (0.0605) & (0.0609) & (0.0607) & (0.0640) \\ -0.0544 & -0.0626 & -0.0659 & -0.0596 \\ (0.0722) & (0.0738) & (0.0701) & (0.0736) \\ 0.103 * * & 0.0666 & 0.0162 & 0.0208 \\ (0.0519) & (0.0543) & (0.0560) & (0.0559)\end{array}$

Manufacturing of textile/

wearing apparel

Manufacturing

(remaining sectors)

(0.0519)

(0.0543)

(0.0560)

$-0.131$

-0.129
$(0.0990)$

$-0.105$

$-0.126$

(0.101)

and leather

$-0.00999$

(0.0985)

(0.0967)

$-0.0287$

(0.0743)

$-0.0157$

$-0.0219$

(0.0738)

Retail electric, phones,
household appliances

$-0.161 \%$

(0.0734)

(0.0716)

$-0.135$

(0.0830)

$-0.156^{*}$

(0.0833)

$-0.129$

(0.0843)

(remaining sectors)

$-0.0858$

(0.0649)

$-0.0830$

(0.0828)

$-0.103$

(0.0649)

(0.0657)

(0.0696)

\begin{tabular}{lccccc} 
Constant & $-0.168 * * *$ & $-0.172 * * *$ & $-0.275 * * *$ & $-0.517 * * *$ & $-0.431 * * *$ \\
& $(0.0180)$ & $(0.0557)$ & $(0.0625)$ & $(0.0754)$ & $(0.0961)$ \\
\hline Wave dummies & \multicolumn{5}{c}{ Yes } \\
\hline Observations & 1,129 & 1,129 & 1,128 & 1,128 & 1,117 \\
Adjusted R-squared & 0.168 & 0.201 & 0.209 & 0.236 & 0.252 \\
\hline
\end{tabular}

Notes: "Tertiary education" is the baseline category for the entrepreneur education variables. The baseline category for the industry controls is industry 1 ("Hair dressing and beauty"). The baseline category for the year controls is the year 2013. Robust standard errors in parentheses. Significance levels: *** $\mathrm{p}<0.01, * * \mathrm{p}<0.05, * \mathrm{p}<0.1$ 


\subsubsection{Robustness checks}

We test the robustness of the results to different estimation techniques, changes in the profit measure, and sample choice.

The previously conducted two-step approach may suffer from the small number of workers per firm, which may affect the estimated fixed effect. Therefore, we estimate the model in one single step instead of two steps. This can yield potential efficiency gains from "borrowing strength" (Lewis \& Linzer, 2005), especially in this case where the amount of information available to estimate the level 1 (worker) effects in each level 2 unit (firm) is small relative to the number of level 2 units. Worker and firm controls are included into one single regression and the model is estimated in one single stage estimation. To model the data structure correctly and account for unobserved firm effects, a multilevel model with a random intercepts and random coefficients is applied. The model looks as follows:

$$
\text { wage }_{i j t}=\beta_{0}+\left(\beta_{1}+\xi_{2 j}\right) \pi_{j t}+\beta_{3} F_{j t}+\beta_{4} I_{i j t}+\gamma_{t}+\xi_{1 j}+\epsilon_{i j t}
$$

where the dependent variable wage $_{i j t}$ is the $\log$ of the hourly wage for worker $i$ at firm $j$ in year $t$, which is explained by a vector of observable firm characteristics $F_{j t}$, a vector of worker specific characteristics $I_{i j t}$, and the main explanatory variable of interest, firm profit $\pi_{j t}$, which varies over firms. $\xi_{2 j}$ is the firm-specific random deviation from the slope $\beta_{1}$, which is fixed for all micro enterprises. The firm-specific intercept is given by $\beta_{0}+\xi_{1 j}$, while $\xi_{1 j}+\xi_{2 j}+$ $\epsilon_{i j t}$ denotes the full error term. Leaving out $\left(\beta_{1}+\xi_{2 j}\right)$ and estimating $\pi_{i t}$ as part of the firm characteristics $F_{i t}$ specifies the random intercept model. Both multilevel models are estimated using the Maximum-Likelihood-Estimator (MLE). In order to allow for endogenous firm effects, we further estimate a fixed effects model (FE). Robust standard errors are applied to control for the serial correlation of worker observations. Table 21 shows regression results of the model estimated via (I) pooled OLS with cluster-robust standard errors, (II) a multilevel model with random intercept, (III) a multilevel model with random intercept and random coefficient for profit and (IV) a fixed effects model. In all models, the profit coefficient is significant and positive, albeit of a smaller size as in the main specification.

\footnotetext{
${ }^{6}$ i.e. level 1 estimates "borrow" information from the full sample (Lewis and Linzer, 2005)
} 
Table 21: Robustness check: Multilevel model

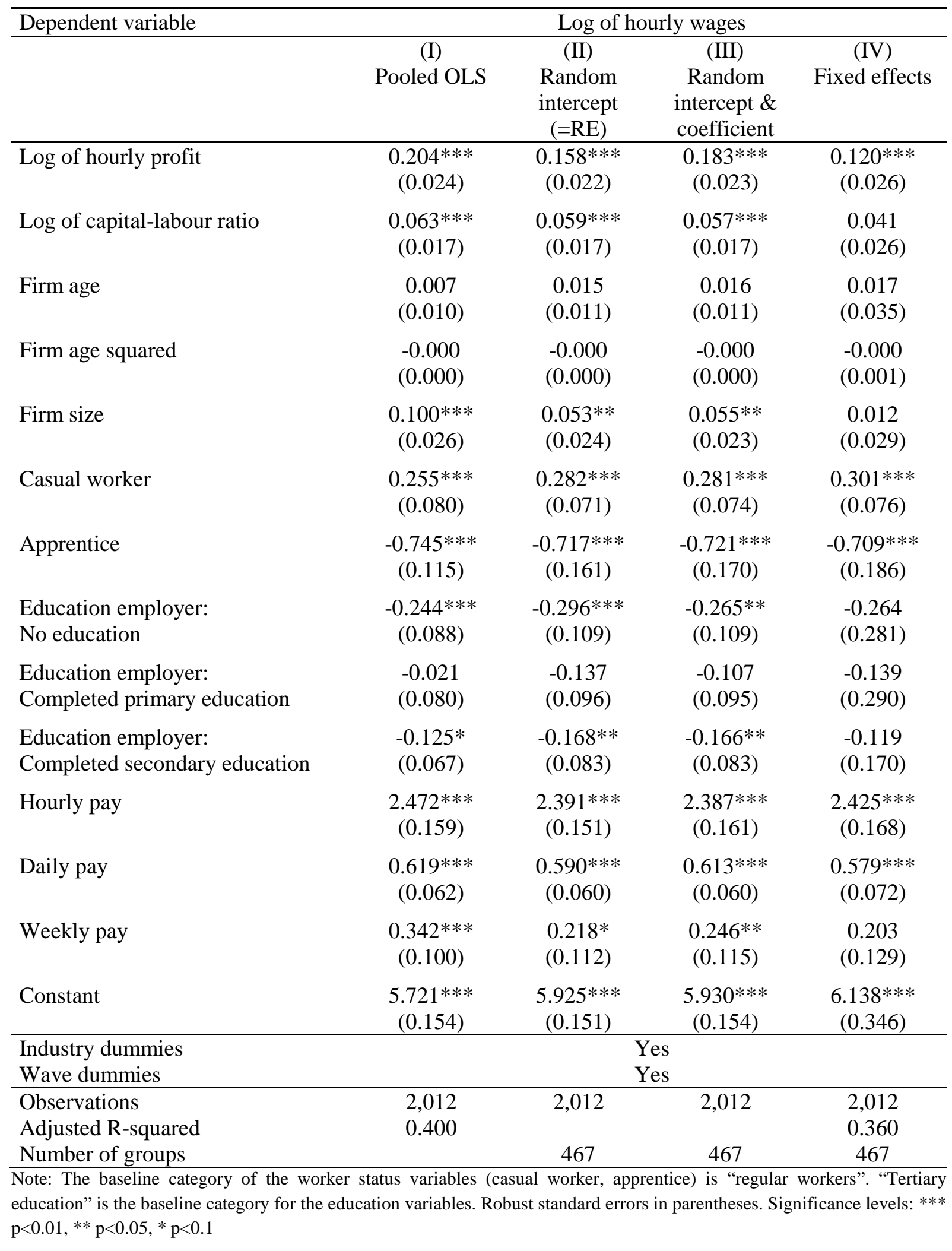

Another challenge in the analysis is the possible endogeneity of profits. Two econometric problems arise when using current profits as an explanatory variable: The first one is the accounting relationship between current profits and wages. Profits are defined as the firms' value added minus the remuneration of labour. Therefore, when wages increase, profits 
automatically decrease. This might result in downward-biased estimates of the relationship between profits and wages. One could argue that value added, which is defined as the firm's sales minus intermediate expenditures (except for raw materials and finished goods), is a more appropriate measure for firm performance as it ignores the wage component. However, de Mel et al. (2009) show that asking firm owners directly for their profits gives a more reasonable and less noisy measure for firm performance than asking for detailed revenue and expenses. Even though true profit levels tend to be understated, self-revealed profit levels seem to be in a reasonable range. In contrast, value added tends to be noisy and results in many negative values. Thus, to avoid the accounting problem of profits by using value added as a performance measure, one would have to accept a potentially much higher measurement error resulting in inconsistent estimates. In our data, value added displays four times more negative values than profits and the standard deviation is about two and a half times larger than the one for profits. We repeat the estimations presented in Table 21 with the logarithmized value added per working hour as explanatory variable. The results are very similar to those presented above using self-reported profits (table not reported).

The second source of endogeneity is in line with efficiency wage theories arguing that higher wages may motivate workers to step up their effort, resulting in higher profits (and accordingly value added). This reversed causality relationship would lead to an upward-biased estimation of the profit coefficient. In order to tackle this simultaneity problem between wages and current profits, the regressions are run with lagged profits instead of current profits.

When using firm-time-fixed effects the sample size decreases to only 272 observations. In these specifications, the coefficient size for the profit variable decreases considerably and loses its significance when introducing further covariates (table not shown here). Due to the small sample size, the statistical power may be insufficient to detect the effect of profit on wages. Therefore, we estimate the regressions using the saved firm-fixed effects (to not lose all observations with only one employee) from the first-step regression as dependent variable and lagged logarithmized profit as explanatory variable. The results are presented in Table 22. 
Table 22: Robustness check, EDV approach, lagged profit

\begin{tabular}{|c|c|c|c|c|c|}
\hline \multirow[t]{2}{*}{ Dependent variable } & \multicolumn{5}{|c|}{ Log of hourly wage premium } \\
\hline & (I) & (II) & $\begin{array}{c}\text { (III) } \\
\text { Pooled OLS }\end{array}$ & (IV) & (V) \\
\hline Lag of log hourly profit & $\begin{array}{c}0.121 * * * \\
(0.020)\end{array}$ & $\begin{array}{c}0.120 * * * \\
(0.021)\end{array}$ & $\begin{array}{c}0.119^{* * * *} \\
(0.021)\end{array}$ & $\begin{array}{c}0.120 * * * \\
(0.021)\end{array}$ & $\begin{array}{c}0.114 * * * \\
(0.021)\end{array}$ \\
\hline Log of capital labour ratio & $\begin{array}{c}0.092 * * * \\
(0.013)\end{array}$ & $\begin{array}{c}0.066 * * * \\
(0.014)\end{array}$ & $\begin{array}{c}0.064 * * * \\
(0.014)\end{array}$ & $\begin{array}{c}0.062 * * * \\
(0.014)\end{array}$ & $\begin{array}{c}0.056 * * * \\
(0.014)\end{array}$ \\
\hline Firm age & & & $\begin{array}{l}0.016^{*} \\
(0.008)\end{array}$ & $\begin{array}{c}0.012 \\
(0.008)\end{array}$ & $\begin{array}{c}0.011 \\
(0.008)\end{array}$ \\
\hline Firm age squared & & & $\begin{array}{l}-0.000 * \\
(0.000)\end{array}$ & $\begin{array}{l}-0.000 \\
(0.000)\end{array}$ & $\begin{array}{l}-0.000 \\
(0.000)\end{array}$ \\
\hline Firm size & & & & $\begin{array}{c}0.083 * * * \\
(0.020)\end{array}$ & $\begin{array}{c}0.084 * * * \\
(0.020)\end{array}$ \\
\hline $\begin{array}{l}\text { Education employer: } \\
\text { No education }\end{array}$ & & & & & $\begin{array}{c}-0.308 * * * \\
(0.096)\end{array}$ \\
\hline $\begin{array}{l}\text { Education employer: } \\
\text { Completed primary } \\
\text { education }\end{array}$ & & & & & $\begin{array}{c}0.005 \\
(0.075)\end{array}$ \\
\hline $\begin{array}{l}\text { Education employer: } \\
\text { Completed secondary } \\
\text { education }\end{array}$ & & & & & $\begin{array}{l}-0.066 \\
(0.061)\end{array}$ \\
\hline Constant & $\begin{array}{c}-0.134 * * * \\
(0.024)\end{array}$ & $\begin{array}{c}-0.157 * * \\
(0.063)\end{array}$ & $\begin{array}{c}-0.247 * * * \\
(0.081)\end{array}$ & $\begin{array}{c}-0.448 * * * \\
(0.096)\end{array}$ & $\begin{array}{c}-0.396 * * * \\
(0.125)\end{array}$ \\
\hline Industry dummies & No & Yes & Yes & Yes & Yes \\
\hline Wave dummies & No & Yes & Yes & Yes & Yes \\
\hline $\begin{array}{l}\text { Observations } \\
\text { Adiusted R-squared }\end{array}$ & $\begin{array}{c}636 \\
0.155\end{array}$ & $\begin{array}{c}636 \\
0.186\end{array}$ & $\begin{array}{c}636 \\
0.188\end{array}$ & $\begin{array}{c}636 \\
0205\end{array}$ & $\begin{array}{c}630 \\
0225\end{array}$ \\
\hline
\end{tabular}

Notes: "No education" is the baseline category for the entrepreneur education variable. Robust standard errors in parentheses. Significance levels: $* * * \mathrm{p}<0.01, * * \mathrm{p}<0.05, * \mathrm{p}<0.1$

Using firm-fixed effects as a measure of the wage premium results in a positive and highly significant profit coefficient across all specifications. The size of the coefficient of lagged profits is about half the size of the coefficient when using current profits ${ }^{7}$. This finding might reflect the dynamic nature of micro enterprises. The characteristics of micro enterprises tend to change fast; therefore, profits lagged by one year might not be the best proxy for present values. The coefficient size of capital intensity has increased, which may stem from the fact that current capital intensity may also reflect current profitability of firms and therefore capture some of the profit effect.

\footnotetext{
${ }^{7}$ Similar results are found for the regression estimated via FGLS (table not shown). Here the coefficient size for the profit variable decreases even further to 0.066 and is only significant at the 10 per cent level. However, one has to keep in mind the small sample size of only 182 observations.
} 
By logarithmizing profits and value added, only firms exhibiting positive values for those performance measures were considered in the regressions. A selection bias would result if negative values for profits present genuine observations that are then not accounted for. In order to address this issue, the model is run using profits/value added calculated with the logmodulus transformation (John \& Draper, 1980). The previous results are robust to this transformation (table not reported here).

There is a risk that worker characteristics, for which we cannot control, bias the estimates. To get a better idea about the potential extent of this bias we estimate the wage regression using only data from 2012. For this year, we additionally have information on worker's tenure, age and gender. Results of this regression are shown in Table B. 2 in the appendix. They can only be indicative, as this estimation is likely to suffer from small sample size, nested error terms and unobserved worker characteristics correlated with the controls. Besides education, the gender of the worker is correlated with wages. Female workers earn significantly less than their male colleagues do. The included worker characteristics can explain about 36 per cent of the variation in logarithmized hourly wages, whereas the education variables alone account for only about 4 per cent of the variation when using the same sample. Thus, the additional worker characteristics may be relevant predictors of workers' wages.

As a last robustness check, the multilevel model is run with a sample excluding influential outliers. The outliers are identified by the DFITS-statistic obtained from a precedent OLS regression (Belsley et al., 1980). The cut-off-value is set at $|D F I T S|=2 \sqrt{k / N}$, with $\mathrm{k}$, the degrees of freedom (plus 1) and $\mathrm{N}$, the number of observations. This reduces the sample by 5 per cent. Yet, the results remain largely unchanged. The estimated profit coefficients are still positive and highly significant (table not shown here).

During the survey period 2012-2018, firms exited the survey and were replaced by new firms. To test for non-random selection, we create a lagged response indicator, which equals one if the firm is observed in the subsequent wave and zero otherwise. We then include the response indicator in the first step regression and test whether it helps to explain the firmspecific wage premium while controlling for other observable firm-level characteristics. The coefficient for the response indicator is not significant, indicating that non-response is not informative. As a second test, we compare the results from our previous estimations using the unbalanced panel (see Table 21) with those using a balanced sub-panel. Using a generalized Hausman test, we cannot reject the hypothesis that the estimated coefficients for the profit variables are equal in both samples. We therefore conclude that non-random selection does not bias our estimation results. 
In summary, the significantly positive relationship between profits and wages is robust to different estimation models, profit measures and sample sizes.

\subsubsection{Profit-wage relation: mechanisms}

The previous results have led to the conclusion that profit is robustly linked to wages. In the first part of this paper, three potential reasons for this correlation have been discussed: rent sharing, risk sharing and efficiency wage theories. In order to investigate the channels through which profits have an effect on wages, the interaction of specific factors with profit are analysed.

\section{Rent sharing}

Previous studies show that workers benefitting the most from increased firm profits are those that are perceived to have higher bargaining power, e.g. men, more tenured workers, more qualified workers (Black \& Strahan, 2001; Fakhfakh \& Fitzroy, 2004; Gartner, 2006; Martins, 2007; Nekby, 2003; Rycx \& Tojerow, 2004). Following the literature (Andreoni et al., 2003; Beegle et al., 2001), bargaining power is measured here as the difference between the educational level of the employer and the employee. The higher the difference between the employer's and the worker's education, the lower the bargaining power of the worker and the easier is it to replace him or her.

Column I and II of Table 23 show the results of the multilevel regression of profits on hourly wages including a measure for the bargaining power of workers, estimated via cluster robust OLS (specification I) and fixed effects (specification II). As expected, the sign of the bargaining power coefficient is negative, indicating that the higher the education of the entrepreneur compared to the worker, the lower is the wage level and the lower is the effect of profit on wages. However, the coefficients are only significant in the OLS specification. This could stem from the fact that the difference in educational levels of entrepreneurs and workers is rather low, as almost half of the workers have the same level of education than their employers. 
Table 23: Profit wage channel - rent sharing

\begin{tabular}{|c|c|c|c|c|}
\hline Dependent variable & & Log of ho & rly wages & \\
\hline & (I) & (II) & (IIII) & (IV) \\
\hline & Pooled OLS & Fixed effects & Pooled OLS & Fixed effects \\
\hline Log of hourly profit & $0.201 * * *$ & $0.123^{* * *}$ & $0.227 * * *$ & $0.125^{* * *}$ \\
\hline & $(0.025)$ & $(0.030)$ & $(0.034)$ & $(0.034)$ \\
\hline Difference in education between & $-0.161 * * *$ & -0.043 & & \\
\hline entrepreneur and worker (continuous) & $(0.040)$ & $(0.044)$ & & \\
\hline Log of hourly profit $x$ difference & -0.009 & -0.016 & & \\
\hline in education & $(0.019)$ & $(0.024)$ & & \\
\hline Entrepreneur has higher education & & & 0.023 & 0.021 \\
\hline than employee & & & $(0.096)$ & $(0.096)$ \\
\hline Log of hourly profit $x$ higher & & & -0.058 & -0.030 \\
\hline education & & & $(0.047)$ & $(0.046)$ \\
\hline Entrepreneur has lower education & & & -0.105 & -0.073 \\
\hline than employee & & & $(0.086)$ & $(0.098)$ \\
\hline Log of hourly profit $x$ lower & & & -0.043 & 0.025 \\
\hline education & & & $(0.044)$ & $(0.044)$ \\
\hline Education employer: & $-0.680 * * *$ & -0.372 & -0.081 & -0.146 \\
\hline No education & $(0.148)$ & $(0.370)$ & $(0.185)$ & $(0.348)$ \\
\hline Education employer: & $-0.286 * *$ & -0.294 & 0.118 & -0.147 \\
\hline Completed primary education & $(0.114)$ & $(0.378)$ & $(0.148)$ & $(0.358)$ \\
\hline Education employer: & $-0.261 * * *$ & -0.177 & -0.071 & -0.118 \\
\hline Completed secondary education & $(0.079)$ & $(0.208)$ & $(0.091)$ & $(0.203)$ \\
\hline Education employee: & -0.055 & 0.004 & 0.121 & 0.062 \\
\hline Completed primary education & $(0.077)$ & $(0.082)$ & $(0.099)$ & $(0.107)$ \\
\hline Education employee: & -0.068 & 0.043 & $0.312 * * *$ & 0.179 \\
\hline Completed secondary education & $(0.065)$ & $(0.070)$ & $(0.119)$ & $(0.134)$ \\
\hline Education employee: & & & $0.581 * * *$ & 0.212 \\
\hline Completed tertiary education & & & $(0.180)$ & $(0.202)$ \\
\hline Constant & $5.941 * * *$ & $6.265^{* * *}$ & $5.387 * * *$ & $6.098 * * *$ \\
\hline & $(0.170)$ & $(0.403)$ & $(0.219)$ & $(0.425)$ \\
\hline Industry dummies & & & & \\
\hline Wave dummies & & & & \\
\hline Observations & 1,949 & 1,949 & 1,949 & 1,949 \\
\hline Adjusted R-squared & 0.413 & 0.653 & 0.413 & 0.653 \\
\hline
\end{tabular}

Notes: Other firm, employer and worker characteristics included but coefficients not shown. "Tertiary education" is the baseline category for the entrepreneur's education variables. "No education" is the baseline category for the employee's education variables. Robust standard errors in parentheses. Significance levels: $* * * p<0.01, * * p<0.05, * p<0.1$ 
The measure for the difference in education between the entrepreneur and the worker is constructed as a continuous variable. However, education is an ordinal variable and the difference between the different education levels may not be equal. To address this problem, we also run the regressions using dummies indicating whether the entrepreneur has a higher or lower education, with same education as baseline category. The results are shown in column III and IV of Table 23. Again, the signs of the coefficients are intuitive, but remain insignificantly different from zero. Using educational differences as a proxy for worker bargaining power may be insufficient. As the analysis of company characteristics has shown, the educational level of the entrepreneur does not play a major role in wage determination. Rather, a suitable measure of bargaining power could be linked to factors such as the experience of the employee or the skill intensity of the respective sector, as it better reflects how relevant the worker is to the firm.

\section{Risk sharing}

To test for risk sharing, we include a measure of the entrepreneur's risk aversion in the wage regression. This measure is based on the answer to the question of how willing the entrepreneur is to take business risks. If risk sharing takes place, we would expect that the positive effect of profit on wages significantly increases with the employer's risk aversion. The results are shown in Table 24, specification (I) and (II). Including a dummy variable equal to one if the employer is risk-averse has no significant effect on wages. Our data contain no information about the employees' risk aversion. Since we cannot track workers over time, the employee's risk aversion may not be constant.

Second, we look at the level of risk the firm is exposed to (Table 24, specification (III) and (IV)). According to the risk-sharing model, the profit-wage relationship should be stronger for firms operating in a high-risk environment. Measuring profit risk as the self-reported maximum profit minus the minimum profit of an ordinary week divided by the firm's monthly profit, we find a significant and positive effect of profit risk on wages. Yet, the effect size is very small. At the 90th percentile of the profit risk distribution, a one per cent increase in firm hourly profits increases the average hourly wage by 0.277 per cent (compared to 0.229 per cent at the 10th percentile). 
Table 24: Profit-wage channel - risk sharing

\begin{tabular}{|c|c|c|c|c|}
\hline \multirow[t]{3}{*}{ Dependent variable } & \multicolumn{4}{|c|}{ Log of hourly wages } \\
\hline & (I) & (II) & (III) & (IV) \\
\hline & \multicolumn{4}{|c|}{ Pooled OLS } \\
\hline Log of hourly profit & $\begin{array}{c}0.195 * * * \\
(0.024)\end{array}$ & $\begin{array}{c}0.120 * * * \\
(0.031)\end{array}$ & $\begin{array}{c}0.212 * * * \\
(0.025)\end{array}$ & $\begin{array}{l}0.128 * * * \\
(0.032)\end{array}$ \\
\hline Entrepreneur is risk averse & $\begin{array}{l}-0.061 \\
(0.071)\end{array}$ & $\begin{array}{l}-0.098 \\
(0.077)\end{array}$ & & \\
\hline Log of hourly profit $\mathrm{x}$ risk aversion & $\begin{array}{c}0.060 \\
(0.068)\end{array}$ & $\begin{array}{c}0.020 \\
(0.075)\end{array}$ & & \\
\hline Profit risk & & & $\begin{array}{l}3.35 \mathrm{e}-04 * * * \\
(8.09 \mathrm{e}-05)\end{array}$ & $\begin{array}{r}2.51 \mathrm{e}-04 * * \\
(1.10 \mathrm{e}-04)\end{array}$ \\
\hline Log of hourly profit $x$ profit risk & & & $\begin{array}{l}7.46 \mathrm{e}-05 * * * \\
(2.12 \mathrm{e}-05)\end{array}$ & $\begin{array}{r}6.24 \mathrm{e}-05^{* *} \\
(2.78 \mathrm{e}-05)\end{array}$ \\
\hline Constant & $\begin{array}{c}5.459 * * * \\
(0.187)\end{array}$ & $\begin{array}{c}6.162 * * * \\
(0.416)\end{array}$ & $\begin{array}{c}5.368 * * * \\
(0.182)\end{array}$ & $\begin{array}{c}5.982 * * * \\
(0.406)\end{array}$ \\
\hline $\begin{array}{l}\text { Industry dummies } \\
\text { Wave dummies }\end{array}$ & & & & \\
\hline Observations & 1,947 & 1,947 & 1,942 & 1,942 \\
\hline Adjusted R-squared & 0.414 & 0.653 & 0.423 & 0.656 \\
\hline
\end{tabular}

Notes: Firm, employer and worker characteristics included but coefficients not shown. Robust standard errors in parentheses. Significance levels: $* * * \mathrm{p}<0.01, * * \mathrm{p}<0.05, * \mathrm{p}<0.1$

\section{Efficiency wages}

According to the efficiency wage model, the positive effect of profit on wages should increase with firm size since it is increasingly difficult to supervise and observe the effort of the worker. The employer hence pays a wage premium to motivate the worker, disincentive shirking and keep productivity high. We already included firm size as a control variable in previous specifications and the coefficient was usually positive and significant. In Table 25 we centre the firm size variable and present the major specifications.

As before, firm size has a positive and significant effect on wages in the pooled OLS specifications. Yet, the interaction term with hourly profit is insignificant across all specifications. Using firm size as a control to test efficiency wage theories is problematic. As Schmidt and Zimmermann (1991) argue, firm size could as well proxy numerous unobserved determinants such as job satisfaction, monitoring costs or more complex technologies. Moreover, the amount of monitoring, supervisors and salaries are simultaneously determined by the firm (Esteves, 2006), rendering firm size endogenous. Therefore, using firm size as a proxy for efficiency wages provides at best indicative results. 
Table 25: Profit-wage channels - efficiency wages

\begin{tabular}{lccc}
\hline \hline Dependent variable & Wage premium & $\begin{array}{c}\text { Log of hourly } \\
\text { wages }\end{array}$ & $\begin{array}{c}\text { Log of hourly } \\
\text { wages }\end{array}$ \\
\hline & $\begin{array}{c}\text { (I) } \\
\text { EDV approach: } \\
\text { Pooled OLS }\end{array}$ & $\begin{array}{c}\text { (II) } \\
\text { Multilevel } \\
\text { model: Pooled } \\
\text { OLS }\end{array}$ & $\begin{array}{c}\text { (III) } \\
\text { Multilevel } \\
\text { model: Fixed } \\
\text { effects }\end{array}$ \\
\hline Log of hourly profit & $0.182^{* * *}$ & $0.186^{* * *}$ & $0.102^{* * *}$ \\
& $(0.0426)$ & $(0.022)$ & $(0.030)$ \\
Centred firm size & $0.171^{* *}$ & $0.139^{* * *}$ & 0.032 \\
& $(0.0760)$ & $(0.038)$ & $(0.048)$ \\
Log of hourly profit x & 0.0419 & 0.022 & 0.022 \\
centred firm size & $(0.0290)$ & $(0.019)$ & $(0.016)$ \\
Centred firm size squared & & & -0.006 \\
& -0.00850 & -0.012 & $(0.008)$ \\
Constant & $(0.0162)$ & $(0.010)$ & $6.172^{* * *}$ \\
& & & $(0.404)$ \\
\hline Industry dummies & $-0.361^{* *}$ & $5.738^{* * *}$ & \\
Wave dummies & $(0.159)$ & $(0.151)$ & 1,949 \\
\hline Observations & & Yes & 0.653 \\
Adjusted R-squared & 501 & 1,949 & Yes \\
\hline \hline
\end{tabular}

Notes: Firm, employer and worker characteristics included but coefficients not shown. Robust standard errors in parentheses. Significance levels: $* * * \mathrm{p}<0.01, * * \mathrm{p}<0.05, * \mathrm{p}<0.1$

\subsection{Conclusions}

The purpose of this paper was to test whether profits have a significantly positive effect on wages in Ugandan micro enterprises. A significant and robust relationship between profit and wages was found. A one per cent increase in hourly profits increases wages by $0.114-0.218$ per cent. This finding contrasts with a perfectly competitive labour market model. It confirms empirical evidence for large firms in developed and developing countries. The results are set into context to three distinct theories of the profit wage relation: rent sharing, risk sharing and the efficiency wage model. We find no evidence for rent sharing using the educational difference between employer and worker as a measure for bargaining power. The profit-wage relationship seems to be stronger for firms experiencing high profit risk - indicating risk sharing - albeit the effect is very small. Finally, our results show that larger firms pay higher wages consistent with efficiency wage models - but this effect does not seem to work through profits. These findings may also be due to the fact that the mechanisms are difficult to operationalize empirically and that many variables - from profits to wages - are measured with a lot of error. 
One of the main difficulties about testing the relationship between profit and wages is worker sorting. Thereby, any observed relationship between profits and wages can potentially be attributed to systematic differences in worker characteristics across firms. By constructing the measure for the wage premium, a firm-specific wage measure that is purged of all observable differences across employees, the likely magnitude of this bias is reduced. However, the set of variables available indicating workers' human capital is small and information on tenure, age and gender of the workers would increase the precision of the estimated wage premium. Systematic differences in unobservable worker characteristics may remain, and therefore this approach certainly does not completely eradicate possible selection bias. Panel data on workers allowing to control for time-invariant differentials in worker productivity would add to the reliability of the results. Yet, one could argue that the firms studied in this paper use dated equipment and work tasks are relatively straightforward. It is unclear why large differences in productivity across firms would evolve due to unobservable worker traits.

Overall, the significantly positive effect of firm performance on workers' wages suggests that when aiming at increasing workers' wages, policymakers should proceed to aim at MSE growth and improve the business environment of MSEs in developing countries. However, further research is needed to get a deeper understanding of the specific mechanisms through which profits are shared with the workers, as the consequential policy implications differ largely. For instance, evidence for efficiency wages can be interpreted as a sign for labour management problems: issues may arise from poor enforcement of labour contracts (shirking) or from difficulties in organizing the workers in the firms, such as task assignment (Fafchamps \& Söderbom, 2006). On the other hand, risk sharing would indicate a need for an expansion of financial institutions accessible for micro entrepreneurs, such as loans and insurance (Bigsten et al., 2003). Moreover, rent sharing due to bargaining power may have important implications for inequality. Previous studies show that workers benefitting the most from firms' profits are also those that are perceived to have higher bargaining power, i.e. men, more tenured and more qualified workers (Fakhfakh \& Fitzroy, 2004; Gartner, 2006; Martins, 2007; Nekby, 2003). In light of this fact, rent sharing might increase gender and other types of inequality. In order to design policies that specifically benefit workers, future research should extend the analysis of these mechanisms to micro enterprises in developing countries. 


\section{REFERENCES}

Abowd, J. \& Kramarz, F. (2004). Are Good Workers Employed by Good Firms? A Simple Test of Positive Assortative Matching Models (Vol. 385). Presented at the Econometric Society 2004 North American Winter Meetings 385, Econometric Society. Retrieved from https://EconPapers.repec.org/RePEc:ecm:nawm04:385

Abowd, J.M., Creecy, R.H. \& Kramarz, F. (2002). Computing Person and Firm Effects Using Linked Longitudinal Employer-Employee Data. Longitudinal Employer-Household Dynamics Technical Papers 2002-06. Retrieved from https://ideas.repec.org/p/cen/tpaper/2002-06.html

Abowd, J.M., Kramarz, F. \& Margolis, D.N. (1999). High Wage Workers and High Wage Firms. Econometrica 67(2): 251-333.

Acemoglu, D. \& Autor, D. (2011). Chapter 12 - Skills, Tasks and Technologies: Implications for Employment and Earnings. In D. Card \& O. Ashenfelter (eds.), Handbook of Labor Economics (Vol. 4, Part B). Amsterdam, Netherlands: Elsevier. Retrieved from http://www.sciencedirect.com/science/article/pii/S0169721811024105

Akerlof, G.A. (1982). Labor Contracts as Partial Gift Exchange. The Quarterly Journal of Economics 97(4): 543-569.

Aldrich, H.E. \& Waldinger, R. (1990). Ethnicity and entrepreneurship. Annual Review of Sociology 16: 111-135.

Ali, M. \& Peerlings, J. (2011). Ethnic Ties in Trade Relationships and the Impact on Economic Performance: The Case of Small-Scale Producers in the Handloom Sector in Ethiopia. Journal of Development Studies 47(8): 1241-1260.

Aliaga-Isla, R. \& Rialp, A. (2013). Systematic review of immigrant entrepreneurship literature: previous findings and ways forward. Entrepreneurship \& Regional Development 25(910): 819-844.

Anderson, S. \& Baland, J.-M. (2002). The Economics of Roscas and Intrahousehold Resource Allocation. The Quarterly Journal of Economics 117(3): 963-995.

Andreoni, J., Brown, E. \& Rischall, I. (2003). Charitable Giving by Married Couples: Who Decides and Why Does It Matter? The Journal of Human Resources 38(1): 111-133.

Angrist, J. \& Pischke, J.-S. (2009). Mostly Harmless Econometrics: An Empiricist's Companion. Princeton, USA: Princeton University Press.

Arai, M. (2003). Wages, Profits, and Capital Intensity: Evidence from Matched Worker-Firm Data. Journal of Labor Economics 21(3): 593-618.

Arbache, J.S. (2001). Wage Differentials in Brazil: Theory and Evidence. Journal of Development Studies 38(2): 109-130. 
Aterido, R., Hallward-Driemeier, M. \& Pagés, C. (2011). Big Constraints to Small Firms' Growth? Business Environment and Employment Growth across Firms. Economic Development and Cultural Change 59(3): 609-647.

Azevedo, J.P., Inchauste, G., Olivieri, S., Saavedra, J. \& Winkler, H. (2013). Is labor income responsible for poverty reduction? a decomposition approach. Policy Research Working Paper (6414). Retrieved from http://papers.ssrn.com/sol3/papers.cfm?abstract_id=2253784

Baily, M.N. (1974). Wages and Employment under Uncertain Demand. Review of Economic Studies 41(1): 37-50.

Baland, J.-M., Bonjean, I., Guirkinger, C. \& Ziparo, R. (2016). The economic consequences of mutual help in extended families. Journal of Development Economics 123: 38-56.

Baland, J.-M., Guirkinger, C. \& Mali, C. (2011). Pretending to Be Poor: Borrowing to Escape Forced Solidarity in Cameroon. Economic Development and Cultural Change 60(1): 116.

Banerjee, A. \& Munshi, K. (2004). How Efficiently is Capital Allocated? Evidence from the Knitted Garment Industry in Tirupur. Review of Economic Studies 71: 19-42.

Banerjee, A.V. \& Duflo, E. (2005). Chapter 7 - Growth Theory through the Lens of Development Economics. In P. Aghion \& S. N. Durlauf (eds.), Handbook of Economic Growth (Vol. 1). Elsevier. Retrieved from http://www.sciencedirect.com/science/article/pii/S1574068405010075

Banerjee, A.V. \& Duflo, E. (2011). Poor Economics: A Radical Rethinking of the Way to Fight Global Poverty. New York, NY: Public Affairs.

Banerjee, A.V. \& Duflo, E. (2014). Do Firms Want to Borrow More? Testing Credit Constraints Using a Directed Lending Program. The Review of Economic Studies 81(2): 572-607.

Banerjee, A.V. \& Newman, A.F. (1993). Occupational Choice and the Process of Development. Journal of Political Economy 101(2): 274-298.

Barr, A.M. (2000). Social capital and technical information flows in the Ghanaian manufacturing sector. Oxford Economic Papers 52: 539-559.

Barr, A.M. (2002). The functional diversity and spillover effects of social capital. Journal of African Economies 11(1): 90-113.

Bates, T. (2011). Minority entrepreneurship. Foundations and Trends in Entrepreneurship Vol. 7(Nos. 3-4): 151-311.

Bates-Earner, N., Carin, B., Lee, M.H., Lim, W. \& Kapila, M. (2012). Post-2015 Development Agenda: Goals, Targets and Indicators - Special Report. Waterloo: CIGI, KDI. Retrieved from https://www.cigionline.org/sites/default/files/MDG_Post_2015v3.pdf

Beegle, K., Frankenberg, E. \& Thomas, D. (2001). Bargaining Power within Couples and Use of Prenatal and Delivery Care in Indonesia. Studies in Family Planning 32(2): 130-146. 
Belsley, D.A., Kuh, E. \& Welsch, R.E. (1980). Regression Diagnostics: Identifying Influential Data and Sources of Collinearity. New York, NY: John Wiley.

Besamusca, J. \& Tijdens, K. (2012). Wages in Uganda. Wage Indicator Survey 2012. Wage Indicator Data Report.

Beveridge, A.A. (1974). Economic Independence, Indigenization, and the African Businessman: Some Effects of Zambia's Economic Reforms. African Studies Review 17(3): 477-490.

Bhowan, K. \& Tewari, D.D. (1997). Indian Entrepreneurs in South Africa: Challenges and Achievements during the Apartheid Era. Journal of Entrepreneurship 6(2): 165-178.

Bierwirth, C. (1999). The Lebanese Communities of Côte d'Ivoire. African Affairs 98(390): 79-99.

Biggs, T., Raturi, M. \& Srivastava, P. (2002). Ethnic networks and access to credit: evidence from the manufacturing sector in Kenya. Journal of Economic Behavior \& Organization 49(4): 473-486.

Biggs, T. \& Shah, M.K. (2006). African SMES, networks, and manufacturing performance. Journal of Banking \& Finance 30(11): 3043-3066.

Bigsten, A., Collier, P., Dercon, S., Fafchamps, M., Gauthier, B., Gunning, J.W., ... Zeufack, A. (2003a). Risk Sharing in Labor Markets. The World Bank Economic Review 17(3): 349-366.

Bigsten, A., Collier, P., Dercon, S., Fafchamps, M., Gauthier, B., Gunning, J.W., ... Zeufack, A. (2003b). Credit constraints in manufacturing enterprises in Africa. Journal of African Economies 12(1): 104-125.

Black, S.E. \& Strahan, P.E. (2001). The Division of Spoils: Rent-Sharing and Discrimination in a Regulated Industry. The American Economic Review 91(4): 814-831.

Blanchflower, D., Oswald, A. \& Sanfey, P. (1996). Wages, Profits, and Rent-Sharing. The Quarterly Journal of Economics 111(1): 227-251.

Bloom, D. \& McKenna, M. (2015). Population, Labour Force and Unemployment: implications for the Creation of (Decent) Jobs, 1990-2030. UNDP Report Office.

Böhme, M.H. \& Thiele, R. (2014). Informal-Formal Linkages and Informal Enterprise Performance in Urban West Africa. The European Journal of Development Research 26(4): 473-489.

Bonacich, E. (1973). A Theory of Middleman Minorities. American Sociological Review 38(5): 583.

Borjas, G.J. (1987). Self-Selection and the Earnings of Immigrants. American Economic Review 77(4): 531-553.

Bräutigam, D. (2003). Close encounters: Chinese business networks as industrial catalysts in Sub-Saharan Africa. African Affairs 102(408): 447-467. 
Breaugh, J.A. (1981). Relationships between Recruiting Sources and Employee Performance, Absenteeism, and Work Attitudes. Academy of Management Journal 24(1): 142-147.

Brown, C. \& Medoff, J.L. (2003). Firm Age and Wages. Journal of Labor Economics 21(3): 677-697.

Bruhn, M. \& McKenzie, D. (2014). Entry Regulation and the Formalization of Microenterprises in Developing Countries. The World Bank Research Observer 29: 186-201.

Buchan, N., T. A. Croson, R. \& M Dawes, R. (2002). Swift Neighbors and Persistent Strangers: A Cross-Cultural Investigation of Trust and Reciprocity in Social Exchange. American Journal of Sociology 108(1): 168-206.

Burchell, B., Sehnbruch, K., Piasna, A. \& Agloni, N. (2014). The quality of employment and decent work: definitions, methodologies, and ongoing debates. Cambridge Journal of Economics 38(2): 459-477.

Burton, P., Gurrin, L. \& Sly, P. (1998). Extending the simple linear regression model to account for correlated responses: An introduction to generalized estimating equations and multilevel mixed modelling. Statistics in Medicine 17(11): 1261-1291.

Cable, V. (1969). The Asians of Kenya. African Affairs 68(272): 218-231.

Cabral, L.M.B. \& Mata, J. (2003). On the Evolution of the Firm Size Distribution: Facts and Theory. American Economic Review 93(4): 1075-1090.

Card, D., Cardoso, A.R., Heining, J. \& Kline, P. (2018). Firms and Labor Market Inequality: Evidence and Some Theory. Journal of Labor Economics 36(S1): S13-S70.

Cardoso, A.R. (2000). Wage Differentials across Firms: An Application of Multilevel Modelling. Journal of Applied Econometrics 15(4): 343-354.

Cardoso, A.R. \& Portela, M. (2009). Micro Foundations for Wage Flexibility: Wage Insurance at the Firm Level. Scandinavian Journal of Economics 111(1): 29-50.

Carney, M. (2007). Minority family business in emerging markets: Organization forms and competitive advantage. Family Business Review 20(4): 289-300.

Carter, M.R. \& Castillo, M. (2005). Coping with disaster. In C. Brendan Barrett (ed.), The Social Economics of Poverty: on Identities, Communities, Groups, and Networks. London; New York: Routledge.

Carter, S. \& Jones-Evans, D. (eds.). (2009). Enterprise and Small Business: Principles, Practice and Policy (2nd ed.). Harlow, United Kingdom: Pearson Education Limited. Retrieved from https://doi.org/10.1108/sd.2009.05625eae.001

Chi, N. \& Nordman, C.J. (2018). Household Entrepreneurship and Social Networks: Panel Data Evidence from Vietnam. The Journal of Development Studies 54(4): 594-618.

Chirinko, R.S., Fazzari, S.M. \& Meyer, A.P. (1999). How responsive is business capital formation to its user cost?: An exploration with micro data. Journal of Public Economics 74(1): 53-80. 
Chua, A. (2003). World on fire: How exporting free market democracy breeds ethnic hatred and global instability. New York, USA: Anchor Books.

Correia, S. (2015). Singletons, Cluster-Robust Standard Errors and Fixed Effects: A Bad Mix. Retrieved from http://scorreia.com/research/singletons.pdf

Court, J., Hyden, G. \& Mease, K. (2003). The Judiciary and Governance in 16 Developing Countries. World Governance Survey Discussion Paper 9: 28.

Crawford, D. (2000). Chinese capitalism: cultures, the Southeast Asian region and economic globalisation. Third World Quarterly 21(1): 69-86.

Criscuolo, C. (2000). Employer Size - Wage Effect: A Critical Review and an Econometric Analysis. University of Siena Economics Working Paper 227. Retrieved from https://papers.ssrn.com/abstract=223546

De Mel, S., McKenzie, D. \& Woodruff, C. (2008). Returns to capital in microenterprises: evidence from a field experiment. The Quarterly Journal of Economics 123(4): 13291372 .

De Mel, S., McKenzie, D.J. \& Woodruff, C. (2009). Measuring microenterprise profits: Must we ask how the sausage is made? Journal of Development Economics 88(1): 19-31.

Deaton, A. (2005). Measuring poverty in a growing world (or measuring growth in a poor world). Review of Economics and Statistics 87(1): 1-19.

Di Falco, S. \& Bulte, E. (2011). A Dark Side of Social Capital? Kinship, Consumption, and Savings. Journal of Development Studies 47(8): 1128-1151.

Dinh, Q.H., Dufhues, T. \& Buchenrieder, G. (2012). Do Connections Matter? Individual Social Capital and Credit Constraints in Vietnam. The European Journal of Development Research 24(3): 337-358.

Dobler, G. (2009). Chinese Shops and the Formation of a Chinese Expatriate Community in Namibia. The China Quarterly 199: 707-727.

Dodlova, M., Göbel, K., Grimm, M. \& Lay, J. (2015). Constrained firms, not subsistence activities: Evidence on capital returns and accumulation in Peruvian microenterprises. Labour Economics 33: 94-110.

Duflo, E., Kremer, M. \& Robinson, J. (2011). Nudging Farmers to Use Fertilizer: Theory and Experimental Evidence from Kenya. American Economic Review 101(6): 2350-90.

ECOSOC. (2014). Millennium Development Goals and post-2015 Development Agenda. Retrieved 13 June 2014, from http://www.un.org/en/ecosoc/about/mdg.shtml

Egbert, H., Fischer, G. \& Bredl, S. (2011). Different Background- Similar Strategies: Recruitment in Tanzanian-African and Tanzanian-Asian Companies. The Journal of Entrepreneurship 20(2): 189-205.

Esman, M. (1987). Ethnic Politics and Economic Power. Comparative Politics 19(4): 395-418. 
Esteves, L. (2006). A note on intensity of supervision in the Brazilian industries. Revista Brasileira de Economia 60: 235-246.

European Commission. (2004). Aid Delivery Methods: Volume 1 - Project Cycle Management Guidelines. $\quad$ Retrieved from http://ec.europa.eu/europeaid/sites/devco/files/methodology-aid-delivery-methodsproject-cycle-management-200403_en_2.pdf

Evans, D.S. \& Jovanovic, B. (1989). An estimated model of entrepreneurial choice under liquidity constraints. Journal of Political Economy 97: 808-827.

Fafchamps, M. (1996). The Enforcement of Commercial Contracts in Ghana. World Development 24(3): 427-448.

Fafchamps, M. (2000). Ethnicity and credit in African manufacturing. Journal of Development Economics 61(1): 205-235.

Fafchamps, M. (2001a). Networks, Communities and Markets in Sub-Saharan Africa: Implications for Firm Growth and Investment. Journal of African Economies 10(AERC Supplement 2): 109-142.

Fafchamps, M. (2001b). The role of business networks in market development in sub-Saharan Africa. Community and Market in Economic Development 186-215.

Fafchamps, M. (2004). Market institutions in Sub-Saharan Africa: Theory and evidence. Cambridge, USA: The MIT Press.

Fafchamps, M. \& Gubert, F. (2007). The formation of risk sharing networks. Papers from a Symposium: The Social Dimensions of Microeconomic Behaviour in Low-Income Communities 83(2): 326-350.

Fafchamps, M. \& Lund, S. (2003). Risk-sharing networks in rural Philippines. Journal of Development Economics 71(2): 261-287.

Fafchamps, M., McKenzie, D., Quinn, S. \& Woodruff, C. (2011a). When is Capital Enough to Get Female Enterprises Growing? Evidence from a Randomized Experiment in Ghana. Retrieved from http://papers.ssrn.com/sol3/papers.cfm?abstract_id=1904244

Fafchamps, M., McKenzie, D., Quinn, S. \& Woodruff, C. (2014). Microenterprise growth and the flypaper effect: Evidence from a randomized experiment in Ghana. Journal of Development Economics 106: 211-226.

Fafchamps, M., McKenzie, D., Quinn, S.R. \& Woodruff, C. (2011b). When is capital enough to get female microenterprises growing? Evidence from a randomized experiment in Ghana. Policy Research Working Paper Series 5706. Retrieved from http://www.nber.org/papers/w17207

Fafchamps, M. \& Minten, B. (2002). Returns to social network capital among traders. Oxford Economic Papers 54(2): 173-206.

Fafchamps, M. \& Söderbom, M. (2006). Wages and Labor Management in African Manufacturing. Journal of Human Resources XLI(2): 356-379. 
Fakhfakh, F. \& Fitzroy, F. (2004). Basic Wages and Firm Characteristics: Rent Sharing in French Manufacturing. LABOUR 18: 615-631.

Fazzari, S.M., Hubbard, R.G. \& Petersen, B.C. (1988). Financing constraints and corporate investment. Brookings Papers on Economic Activity 1: 141-206.

Fields, G. (2005). A guide to multisector labor market models. Social Protection Discussion Paper 505.

Fisman, R. \& Svensson, J. (2007). Are corruption and taxation really harmful to growth? Firm level evidence. Journal of Development Economics 83(1): 63-75.

Fisman, R.J. (2003). Ethnic ties and the provision of credit: Relationship-level evidence from African firms. Advances in Economic Analysis \& Policy 3(1). Retrieved from http://www.degruyter.com/view/j/bejeap.2003.3.issue-

1/bejeap.2003.3.1.1211/bejeap.2003.3.1.1211.xml

Freedman, M. (1959). The handling of money: A note on the background to the economic sophistication of the overseas Chinese. Man 59: 64-65.

Freedman, M. (1979). The Study of Chinese Society: Essays. (G.W. Skinner, ed.). Redwood City CA, USA: Stanford University Press.

Gadzala, A. (2009). Survival of the fittest? Kenya's jua kali and Chinese businesses. Journal of Eastern African Studies 3(2): 202-220.

Gajigo, O. \& Foltz, J.D. (2010). Ethnic Networks and Enterprise Credit: The Serahules of The Gambia. Presented at the 2010 annual meeting. Agricultural and Applied Economics Association, Denver, Colorado; USA.

Gartner, H. (2006). Gender Wage Inequality and Rent-Sharing: Evidence from a GermanLinked Employer-Employee Data-set. In B. Mahy, R. Plasnman \& F. Rycx (eds.), Gender Pay Differentials. London: Palgrave Macmillan.

Ghai, D.P. \& Ghai, Y.P. (1965). Asians in East Africa: Problems and Prospects. The Journal of Modern African Studies 3(01): 35-51.

Glaeser, E.L., Laibson, D.I., Scheinkman, J.A. \& Soutter, C.L. (2000). Measuring Trust. The Quarterly Journal of Economics 115(3): 811-846.

Godfrey, A.B. (2007). The migrations and identity of Indo-Pakistani minorities in Uganda. Paper presented to the French Institute for Research in Africa, Nairobi, Kenya.

Goldin, C. \& Katz, L.F. (2009). The Race between Education and Technology: The Evolution of U.S. Educational Wage Differentials, 1890 to 2005. NBER Working Paper 12984.

Goodwin, B. (2006). The Path to a Smarter Globalization-Overcoming the Ethnonationalist Challenge to Free Market Democracy: A Case Study of the Lebanese Diaspora in Senegal. University of Pennsylvania. Retrieved from http://2010ciberlc.lauder.wharton.upenn.edu/pages/pdf/student_thesis/The_path_to_a_ smarter_globalization_Overcoming_the_ethnonationalist.pdf 
Greif, A. (1993). Contract Enforceability and Economic Institutions in Early Trade: The Maghribi Traders' Coalition. American Economic Review 83(3): 525-548.

Grimm, M., Guber, F., Koriko, O., Lay, J. \& Nordman, C. (2013). Kinship ties and entrepreneurship in Western Africa. Journal of Small Business \& Entrepreneurship 26.2: $125-150$.

Grimm, M., Hartwig, R. \& Lay, J. (2012a). How Much Does Utility Access Matter for the Performance of Micro and Small Enterprises? World Bank. Retrieved from https://doi.org/10.1596/26782

Grimm, M., Knorringa, P. \& Lay, J. (2012b). Constrained Gazelles: High Potentials in West Africa's Informal Economy. World Development 40(7): 1352-1368.

Grimm, M., Krüger, J. \& Lay, J. (2011). Barriers To Entry And Returns To Capital In Informal Activities: Evidence From Sub-Saharan Africa. Review of Income and Wealth 57: 2753.

Grootaert, C., Oh, G.-T. \& Swamy, A.V. (2002). Social capital, household welfare and poverty in Burkina Faso. Journal of African Economies 11(1): 4-38.

Guiso, L., Sapienza, P. \& Zingales, L. (2004). The Role of Social Capital in Financial Development. American Economic Review 94(3): 526-556.

Gutierrez, F.H. (2013). Labor Contracts and Risk Sharing. Background paper for World Development Report 2014. Retrieved from /paper/Labor-Contracts-and-Risk-SharingGutierrez/9715c4abbd131e9d914cd0594439e389d8d21b6f

Hadnes, M., Vollan, B. \& Kosfeld, M. (2013). The dark side of solidarity. Unpublished manuscript, Goethe-University Frankfurt. Retrieved from https://econresearch.uchicago.edu/sites/econresearch.uchicago.edu/files/Hadnes, $\% 20 \mathrm{~V}$ ollan\%20and\%20Kosfeld\%202013_The\%20Dark\%20Side.pdf

Hanushek, E.A. (1974). Efficient Estimators for Regressing Regression Coefficients. The American Statistician 28(2): 66-67.

Harrison, P., Moyo, K. \& Yang, Y. (2012). Strategy and Tactics: Chinese Immigrants and Diasporic Spaces in Johannesburg, South Africa. Journal of Southern African Studies 38(4): 899-925.

Hart, K. (1973). Informal Income Opportunities and Urban Employment in Ghana. The Journal of Modern African Studies 11(1): 61-89.

Haugen, H.Ø. \& Carling, J. (2005). On the edge of the Chinese diaspora: The surge of baihuo business in an African city. Ethnic and Racial Studies 28(4): 639-662.

Hicks, J.R. (1935). Wages and interest: the dynamic problem. The Economic Journal 45(179): 456-468.

High Level Committee on the Indian Diaspora. (2001). Report of the High Level Committee on the Indian Diaspora. Retrieved from http://indiandiaspora.nic.in 
Hildreth, A.K.G. \& Oswald, A. (1997). Rent-Sharing and Wages: Evidence from Company and Establishment Panels. Journal of Labor Economics 15(2): 318-37.

Hill, R. (1970). New Look at Employee Referrals. Personnel Journal 49: 144-8.

Himbara, D. (1994). The failed Africanization of commerce and industry in Kenya. World Development 22(3): 469-482.

Hoff, K. \& Sen, A. (2006). The kin system as a poverty trap. In S. Bowles, S. Durlauf \& K. Hoff (eds.), Poverty traps. Princeton, USA: Princeton University Press.

Hubbard, R.G. (1998). Capital-Market Imperfections and Investment. Journal of Economic Literature 36(1): 193-225.

Ilhan-Nas, T., Sahin, K. \& Cilingir, Z. (2011). International ethnic entrepreneurship: Antecedents, outcomes and environmental context. International Business Review 20(6): 614-626.

ILO. (1999). ILC87 - Report of the Director-General: Decent work. Retrieved 5 August 2014, from http://www.ilo.org/public/english/standards/relm/ilc/ilc87/repi.htm\#1.\%20The\%20primary\%20goal

ILO. (2009). Guide to the new Millennium Development Goals Employment indicators: including the full decent work indicator set. Geneva: ILO.

ILO. (2012a). Jobs and livelihoods at the heart of the post-2015 development agenda. ILO Concept Note for the post-2015 development agenda (1). Retrieved from http://www.ilo.org/wcmsp5/groups/public/---dgreports/--dcomm/documents/statement/wcms_205641.pdf

ILO. (2012b). Understanding deficits of productive employment and setting targets: $a$ methodological guide. Geneva: ILO.

ILO. (2013). Jobs and livelihoods in the post-2015 development agenda: Meaningful ways to set targets and monitor progress. ILO Concept Note for the post-2015 development agenda (2). Retrieved from http://www.ilo.org/wcmsp5/groups/public/---dgreports/--dcomm/documents/genericdocument/wcms_213309.pdf

ILO. (2014). Social protection. Retrieved 5 August 2014, from http://www.ilo.org/global/about-the-ilo/decent-work-agenda/social-protection/lang-en/index.htm

ILO. (2018). World Employment and Social Outlook - Trends 2018.

ILO. (2019a). Safety and health at the hearth of the future of work: Building on 100 years. Retrieved from https://www.ilo.org/wcmsp5/groups/public/---ed_protect/---protrav/--safework/documents/publication/wcms_687610.pdf

ILO (ed.). (2019b). World Employment and Social Outlook - Trends 2019.

Inchauste, G., Saavedra, J., Winkler, H., Azevedo, J.P. \& Olivieri, S. (2012). When job earnings are behind poverty reduction. Economic Premise 97: 1-6. 
Jenssen, J.I. \& Kristiansen, S. (2004). Sub-cultures and Entrepreneurship: The Value of Social Capital in Tanzanian Business. Journal of Entrepreneurship 13(1): 1-27.

John, J.A. \& Draper, N.R. (1980). An Alternative Family of Transformations. Journal of the Royal Statistical Society. Series C (Applied Statistics) 29(2): 190-197.

Jørgensen, J.J. (1981). Uganda: A Modern History. London, United Kingdom: Croom Helm. Retrieved from https://books.google.de/books?id=09MNAAAAQAAJ

Kabeer, N. (2005). Gender equality and women's empowerment: A critical analysis of the third millennium development goal. Gender \& Development 13(1): 13-24.

Kar, S. \& Datta, D. (2015). Industrial and Labor Economics: Issues in Developing and Transition Countries. New Delhi, India: Springer India.

Katz, L.F. (1986). Efficiency wage theories: a partial evaluation. NBER Macroeconomics Annual 1.

Katz, L.F. \& Autor, D.H. (1999). Changes in the Wage Structure and Earnings Inequality. In O. Ashenfelter \& D. Card (eds.), Handbook of Labor Economics, vol. 3A. Amsterdam, Netherlands: Elsevier.

Kernen, A. \& Vulliet, B. (2009). Petits commerçants et entrepreneurs chinois au Mali et au Sénégal. Afrique contemporaine 228(4): 69-94.

Khan Mohammad, G. (2014). The Chinese Presence in Burkina Faso: A Sino-African Cooperation from Below. Journal of Current Chinese Affairs 43(1): 71-101.

Kilby, P. (1983). An entrepreneurial problem. The American Economic Review 107-111.

Kim, M., Surroca, J. \& Tribó, J.A. (2014). Impact of ethical behavior on syndicated loan rates. Journal of Banking \& Finance 38(C): 122-144.

Kinghan, C. \& Newman, C. (2015). Social capital, political connections, and household enterprises. WIDER Working Paper 2015/001. Retrieved from http://www.wider.unu.edu/publications/working-papers/2015/en_GB/wp2015001/_files/93141573571717252/default/wp2015-001.pdf

Kloostermann, R. \& Rath, J. (eds.). (2003). Immigrant Entrepreneurs: Venturing Abroad in the Age of Globalization. Oxford, UK; New York, USA: Berg Publishers. Retrieved from https://www.amazon.com/Immigrant-Entrepreneurs-Venturing-AbroadGlobalization/dp/1859736394\#reader_1859736394

Kremer, M., Lee, J.N., Robinson, J. \& Rostapshova, O. (2011). The return to Capital for Small Retailers in Kenya: Evidence from Inventories. Mimeo. Harvard University.

Kristiansen, S. (2004). Social Networks and Business Success: The Role of Subcultures in an African Context. American Journal of Economics and Sociology 63(5): 1149-1171.

Kristiansen, S. \& Ryen, A. (2002). Enacting their Business Environments: Asian Entrepreneurs in East Africa. African and Asian Studies 1(3): 165-186. 
Krueger, A.B. \& Summers, L.H. (1988). Efficiency Wages and the Inter-Industry Wage Structure. Econometrica 56(2): 259-293.

La Ferrara, E. (2010). Family and Kinship Ties in Development: An Economist's Perspective. In J.-P. Platteau \& R. Peccoud (eds.), Culture, Institutions, and Development: New Insights Into an Old Debate. London: Routledge. Retrieved from http://www.afd.fr/webdav/site/afd/shared/PORTAILS/PUBLICATIONS/EUDN/EUD N2007/laferrara.pdf

La Porta, R. \& Shleifer, A. (2008). The Unofficial Economy and Economic Development. Brookings Papers on Economic Activity, Economic Studies Program, The Brooking Institution 39(2): 275-363.

Lavallée, E. \& Roubaud, F. (2019). Corruption in the Informal Sector: Evidence from West Africa. The Journal of Development Studies 55(6): 1067-1080.

Lewis, J.B. \& Linzer, D.A. (2005). Estimating Regression Models in Which the Dependent Variable Is Based on Estimates. Political Analysis 13(4): 345-364.

Light, I. (2007). Global entrepreneurship and transnationalism. In L. P. Dana (ed.), Handbook of research on ethnic minority entrepreneurship. Cheltenham, United Kingdom; Northampton, MA, USA: Edward Elgar.

Lin, E. (2014). "Big Fish in a Small Pond": Chinese Migrant Shopkeepers in South Africa. International Migration Review 48(1): 181-215.

Lin, N. (1999). Building a network theory of social capital. Connections 22(1): 28-51.

Luebker, M. (2011). Labour productivity. In T. Sparreboom \& A. Albee (eds.), Towards Decent Work in sub-Saharan Africa: Monitoring MDG Employment Indicators. Geneva, Switzerland: ILO.

Ma, Z., Zhao, S., Lee, Y. \& Wang, T. (2013). An overview of contemporary ethnic entrepreneurship studies: themes and relationships. International Journal of Entrepreneurial Behavior \& Research 19(1): 32-52.

Mackie, J.A. (1992). Overseas chinese entrepreneurship. Asian-Pacific Economic Literature 6(1): 41-64.

Maloney, W.F. (2004). Informality Revisited. World Development 32(7): 1159-1178.

Martins, P. \& Takeuchi, L.R. (2013). Employment in a post-2015 framework. ODI Working Paper. Retrieved from http://kms2.isn.ethz.ch/serviceengine/Files/ESDP/167996/ipublicationdocument_singl edocument/40b07431-0765-4443-8a2b-40a143378825/en/8503.pdf

Martins, P.S. (2007). Rent sharing and wages. Reflets et prespectives de la vie économique 46(2): 23-31.

Martins, P.S. \& Esteves, L.A. (2006). Is There Rent Sharing In Developing Countries? Matched-Panel Evidence from Brazil. IZA Discussion Paper 2317: 36. 
Masurel, E., Nijkamp, P. \& Vindigni, G. (2004). Breeding places for ethnic entrepreneurs: a comparative marketing approach. Entrepreneurship \& Regional Development 16(1): 77-86.

McCormick, D. (1995). Industrial district or garment ghetto? The case of Nairobi's minimanufacturers. In M. P. Van Dijk \& R. Rabellotti (eds.), Enterprise Clusters and Networks in Developing Countries. London, United Kingdom: Frank Class.

McKenzie, D. \& Woodruff, C. (2006). Do entry costs provide an empirical basis for poverty traps? Evidence from Mexican microenterprises? Economic Development and Cultural Change 55(1): 3-42.

McKenzie, D. \& Woodruff, C. (2008). Experimental Evidence on Returns to Capital and Access to Finance in Mexico. The World Bank Economic Review 22(3): 457-482.

Mead, D.C. \& Liedholm, C. (1998). The Dynamics of Micro and Small Enterprises in Developing Countries. World Development 26(1): 61-74.

Mead, D.C. \& Morrisson, C. (1996). The informal sector elephant. World Development 24(10): $1611-1619$.

Menezes, T.A. \& Raposo, I.P. (2014). Wage differentials by firm size: the efficiency wage test in a developing country. Estudos Econômicos (São Paulo) 44: 45-67.

Mengistae, T. (2001). Indigenous Ethnicity and Entrepreneurial Success in Africa. Policy Research Working Paper 2534. Retrieved from http://books.google.com/books?hl=en\&lr=\&id=dmku-

nJAjOYC\&oi=fnd\&pg=PA13\&dq $=\% 22$ by + the + Policy + Research + Dissemination $\% 22$ $+\% 22$ Policy+Research+Working+Paper+Series+disseminates+the+findings+of+work + in+progress+to+encourage+the+exchange+of+ideas $\% 22+\% 22$ Ethnicity+and+Entrep reneurial+Success+in\%22+\&ots $=8$ _W -

wOZlnl\&sig=oWQN0OuYBQ1FmP1A9wybSfWiSdU

Menkhoff, T. \& Solvay, G. (eds.). (2012). Chinese Entrepreneurship and Asian Business Networks. London, United Kingdom: Routledge.

Mistrulli, P.E. \& Vacca, V. (2015). Social capital and the cost of credit: evidence from a crisis. Temi di discussione (Economic working papers) (1009). Retrieved from https://ideas.repec.org/p/bdi/wptemi/td_1009_15.html

Mohan, G. \& Kale, D. (2007). The invisible hand of South-South globalization: Chinese migrants in Africa. Report for the Rockefeller Foundation, The Open University. Retrieved from http://asiandrivers.open.ac.uk/documents/Rockefeller\%20Report\%20on\%20Chinese\% 20diasporas\%2010th\%200ct\%20_3_.pdf

Monteith, W. \& Giesbert, L. (2016). 'When the stomach is full we look for respect': perceptions of 'good work' in the urban informal sectors of three developing countries. Work, Employment and Society 31(5): 816-833.

Montgomery, J.D. (1991). Social networks and labor-market outcomes: Toward an economic analysis. The American Economic Review 81(5): 1408-1418. 
Morrisson, C. (2006). Structures familales, transferts et épargne: un examen. Centre de développement de l'OCDE, Paris.

Munshi, K. (2014). Community Networks and the Process of Development. Journal of Economic Perspectives 28(4): 49-76.

Nekby, L. (2003). Gender differences in rent sharing and its implications for the gender wage gap, evidence from Sweden. Economics Letters 81(3): 403-410.

Nestorowicz, J. (2012). Immigrant self-employment: definitions, concepts and methods. Central and Eastern European Migration Review 1(1): 37-55.

Nichter, S. \& Goldmark, L. (2009). Small firm growth in developing countries. World Development 37(9): 1453-1464.

Oi, W. \& Idson, T. (1999). Firm size and wages. In O. Ashenfelter \& D. Card (eds.), Handbook of Labor Economics (Vol. 3, Part B). Amsterdam, Netherlands: Elsevier. Retrieved from https://EconPapers.repec.org/RePEc:eee:labchp:3-33

Okten, C. \& Osili, U.O. (2004). Social Networks and Credit Access in Indonesia. World Development 32(7): 1225-1246.

Open Working Group on Sustainable Development Goals. (2014). Outcome Document - Open Working Group on Sustainable Development Goals: Introduction to the Proposal of The Open Working Group for Sustainable Development Goals. Retrieved 4 August 2014, from http://sustainabledevelopment.un.org/focussdgs.html

Peugh, J. (2010). A practical guide to multilevel modeling. Journal of school psychology 48: $85-112$.

Platteau, J.-P. (2000). Institutions, social norms, and economic development. Amsterdam: Harwood Academic Publishers.

Portes, A. \& Sensenbrenner, J. (1993). Embeddedness and Immigration: Notes on the Social Determinants of Economic Action. American Journal of Sociology 98(6): 1320-1350.

Putnam, R.D. (2000). Bowling Alone. New York, USA: Free Press.

Ram, M. \& Smallbone, D. (2002). Ethnic Minority Business Policy in the Era of the Small Business Service. Environment and Planning C: Politics and Space 20(2): 235-249.

Ramachandran, V. \& Shah, M.K. (1999). Minority entrepreneurs and firm performance in subSaharan Africa. The Journal of Development Studies 36(2): 71-87.

Rees, A. (1966). Information Networks in Labor Markets. The American Economic Review 56(1/2): 559-566.

Reinikka, R. \& Svensson, J. (1999). How Inadequate Provision of Public Infrastructure and Services Affects Private Investment. Policy Research Working Papers 2262. Retrieved from https://doi.org/10.1596/1813-9450-2262

Republic of Uganda (ed.). (2010). Uganda National Report for the implementation of the Programme of Action for the Least Developed Countries for the Decade 2001-2010. 
Rooks, G., Dolech, D., Szirmai, A. \& Serwanga, A. (2009). Social Capital and Innovative Performance in Developing Countries: The Case of Ugandan Entrepreneurs. Presented at the GLOBELICS 2009, 7th International Conference, Dakar, Senegal.

Rycx, F. \& Tojerow, I. (2004). Rent sharing and the gender wage gap in Belgium. International Journal of Manpower 25(3/4): 279-299.

Salop, S.C. (1979). A Model of the Natural Rate of Unemployment. The American Economic Review 69(1): 117-125.

Schmidt, C.M. \& Zimmermann, K.F. (1991). Work Characteristics, Firm Size and Wages. The Review of Economics and Statistics 73(4): 705-710.

Schwab, D. (1982). Recruiting and Organizational Participation. In K. Rowland \& G. Ferris (eds.), Personnel Management. Boston, USA: Allyn and Bacon.

Shapiro, C. \& Stiglitz, J.E. (1984). Equilibrium Unemployment as a Worker Discipline Device. The American Economic Review 74(3): 433-444.

Shoji, M., Aoyagi, K., Kasahara, R., Sawada, Y. \& Ueyama, M. (2012). Social Capital Formation and Credit Access: Evidence from Sri Lanka. World Development 40(12): 2522-2536.

Söderbom, M. \& Teal, F. (2001). Firm size and human capital as determinants of productivity and earnings. CSAE Working Paper Series 2001-09. Retrieved from https://ideas.repec.org/p/csa/wpaper/2001-09.html

Söderbom, M., Teal, F. \& Wambugu, A. (2005). Unobserved heterogeneity and the relation between earnings and firm size: evidence from two developing countries. Economics Letters 87(2): 153-159.

Solow, R. (1979). Another possible source of wage stickiness. Journal of Macroeconomics 1(1): 79-82.

Sparreboom, T. \& Albee, A. (2011). Towards decent work in a sub-Saharan Africa: monitoring MDG employment indicators. (International Labour Office, ed.). Geneva: ILO.

Staveren, I. van \& Knorringa, P. (2007). Unpacking social capital in Economic Development: How social relations matter. Review of Social Economy 65(1): 107-135.

Steenbergen, M.R. \& Jones, B.S. (2002). Modeling Multilevel Data Structures. American Journal of Political Science 46(1): 218-237.

Talavera, O., Xiong, L. \& Xiong, X. (2012). Social Capital and Access to Bank Financing: The Case of Chinese Entrepreneurs. Emerging Markets Finance and Trade 48(1): 55-69.

Teal, F. (1996). The Size and Sources of Economic Rents in a Developing Country Manufacturing Labour Market. Economic Journal 106(437): 963-976.

Turner, S. (2007). Small-Scale Enterprise Livelihoods and Social Capital in Eastern Indonesia: Ethnic Embeddedness and Exclusion. The Professional Geographer 59(4): 407-420. 
Udry, C. \& Anagol, S. (2006). The Return to Capital in Ghana. American Economic Review 96(2): 388-393.

UN. (2008). United Nations Millennium Development Goals. Retrieved 19 December 2014, from http://www.un.org/millenniumgoals/poverty.shtml

UN. (2015). Resolution adopted by the General Assembly on 25 September 2015 Transforming our world: the 2030 Agenda for Sustainable Development. Retrieved from https://www.un.org/ga/search/view_doc.asp?symbol=A/RES/70/1\&Lang=E

UNDP (ed.). (2009). Handbook on planning, monitoring and evaluating for development results. $\quad$ Retrieved from http://web.undp.org/evaluation/handbook/documents/english/pme-handbook.pdf

Uzzi, B. (1999). Embeddedness in the Making of Financial Capital: How Social Relations and Networks Benefit Firms Seeking Financing. American Sociological Review 64(4): 481505.

Velenchik, A.D. (1997). Government intervention, efficiency wages, and the employer size wage effect in Zimbabwe. Journal of Development Economics 53(2): 305-338.

WageIndicator.org. (2018). WageIndicator2019: Living Wage Series - Uganda. Retrieved 12 February 2019, from https://wageindicator.org/salary/living-wage/uganda-living-wageseries-january-2018-country-overview

Waldinger, R., Aldrich, H.E. \& Ward, R. (1990). Ethnic entrepreneurs: Immigrant Business in Industrial Societies (Vol. 1). Newbury Park, USA: SAGE Publications.

Wanous, J. (1980). Organizational Entry. Reading, MA: Addison-Wesley.

WHO (ed.). (2018). Workers' health and decent jobs. Retrieved from https://www.who.int/sustainable-development/Factsheet-WorkersHealth230517b.pdf?ua=1

Woodruff, C. \& Zenteno, R. (2007). Migration networks and microenterprises in Mexico. Journal of Development Economics 82(2): 509-528.

Woolcock, M. (2001). Microenterprise and social capital: A framework for theory, research, and policy. The Journal of Socio-Economics 30(2): 193-198.

World Bank (ed.). (2012). World Development Report 2013: Jobs. Washington, DC: World Bank.

Wu, Y.-L. (1983). Chinese entrepreneurs in Southeast Asia. The American Economic Review 73(2): 112-117.

Yen, C. (2013). Ethnic Chinese Business in Asia: History, Culture and Business Enterprise. Singapore, Singapore: World Scientific.

Zakaria, Y. (1999). Entrepreneurial Ethics and Trust: Cultural Foundations and Networks in the Nigerian Plastic Industry. London: Routledge. 
Zhou, M. (2004). Revisiting ethnic entrepreneurship: convergencies, controversies, and conceptual advancements. International Migration Review 38(3): 1040-1074. 


\section{APPENDIX A}

Table A. 1: Basic sample characteristics, by reason for being defined credit-unconstrained

\begin{tabular}{|c|c|c|c|}
\hline & No need & $\begin{array}{l}\text { Always been } \\
\text { granted loan }\end{array}$ & T-test \\
\hline & Mean & Mean & Difference \\
\hline \multicolumn{4}{|l|}{ Individual characteristics } \\
\hline Entrepreneur's age & 44.2 & 44.4 & -0.2 \\
\hline $\begin{array}{l}\text { Share of entrepreneurs that have not } \\
\text { completed primary education }\end{array}$ & 0.0 & 0.0 & 0.0 \\
\hline $\begin{array}{l}\text { Share of entrepreneurs with completed } \\
\text { primary education }\end{array}$ & 0.2 & 0.2 & -0.0 \\
\hline $\begin{array}{l}\text { Share of entrepreneurs with completed } \\
\text { secondary education }\end{array}$ & 0.4 & 0.4 & 0.0 \\
\hline $\begin{array}{l}\text { Share of entrepreneurs with completed } \\
\text { tertiary education }\end{array}$ & 0.3 & 0.3 & 0.0 \\
\hline Entrepreneur's experience & 12.7 & 14.0 & -1.3 \\
\hline Entrepreneur is male & 0.8 & 0.8 & -0.0 \\
\hline \multicolumn{4}{|l|}{ Firm characteristics } \\
\hline MSE age & 14.1 & 15.5 & -1.4 \\
\hline No. of employees (excl. the entrepreneur) & 1.5 & 2.4 & $-0.9 * *$ \\
\hline Monthly profit (in 2012 Rs) & $85,033.5$ & $102,508.9$ & $-17,475.4$ \\
\hline $\begin{array}{l}\text { Owned capital stock, excl. land and } \\
\text { buildings (in } 2012 \text { Rs) }\end{array}$ & $941,344.7$ & $2,244,057.8$ & $-1,302,713.0 * *$ \\
\hline $\begin{array}{l}\text { Owned capital stock, excl. inventories, land } \\
\text { and buildings (in } 2012 \mathrm{Rs)}\end{array}$ & $413,936.9$ & $1,267,547.0$ & $-853,610.1 * *$ \\
\hline \multicolumn{4}{|l|}{ Industry sectors } \\
\hline Manufacture of textiles & 0.1 & 0.1 & -0.0 \\
\hline Manufacture of wood and furniture & 0.2 & 0.3 & $-0.1 * *$ \\
\hline Other manufacturing & 0.1 & 0.1 & -0.0 \\
\hline Wholesale and retail of food and beverages & 0.1 & 0.1 & 0.0 \\
\hline Wholesale and retail of electronics & 0.1 & 0.0 & $0.1 * * *$ \\
\hline Wholesale and retail of wearing apparel & 0.1 & 0.1 & 0.0 \\
\hline Other wholesale and retail & 0.2 & 0.3 & -0.1 \\
\hline Hairdressing and beauty & 0.1 & 0.1 & 0.0 \\
\hline Other services & 0.1 & 0.1 & 0.0 \\
\hline Observations & 609 & 184 & 793 \\
\hline
\end{tabular}

Notes: ${ }^{*} p<0.10,{ }^{* *} p<0.05,{ }^{* * *} p<0.01$ 
Table A. 2: Use of capital sources by capital quartiles

\begin{tabular}{lccccc}
\hline \hline & 1 & 2 & 3 & 4 \\
& $(0-674$ & $(675-1,643$ & $(1,644-3,968$ & $(3,969-1,577,761$ & \\
Source of funds & Int. \$) & Int. \$) & Int. \$ $)$ & Int. \$) & All \\
\hline Start-up capital & & & & & \\
Own savings & 69.28 & 64.67 & 69.44 & 76.22 & 69.82 \\
Formal loan & 10.91 & 10.74 & 15.49 & 16.08 & 13.19 \\
Family loan & 7.88 & 18.00 & 15.60 & 15.38 & 14.02 \\
Loan from money lender & 5.45 & 5.37 & 4.23 & 3.52 & 4.68 \\
Trade loan & 5.45 & 4.03 & 4.20 & 6.29 & 5.00 \\
& & & & & \\
Inventory (only 2012) & & & & & \\
Own savings & 82.09 & 86.84 & 87.90 & 91.30 & 86.86 \\
Formal loan & 5.22 & 2.68 & 1.61 & 1.74 & 2.89 \\
Loan from family or friends & 3.01 & 2.65 & 3.23 & 2.61 & 2.89 \\
Loan from money lender & 10.53 & 2.68 & 0.81 & 2.61 & 4.34 \\
Trade loan & 36.57 & 30.97 & 36.29 & 34.78 & 34.77 \\
\hline
\end{tabular}

Table A. 3: Importance of capital sources by capital quartiles

\begin{tabular}{lcccc}
\hline \hline $\begin{array}{l}\text { Source of funds } \\
\text { (\% of total money borrowed) })\end{array}$ & $\begin{array}{c}\text { (0-674 } \\
\text { Int. \$) }\end{array}$ & $\begin{array}{c}\text { (675-1,643 } \\
\text { Int. \$) }\end{array}$ & $\begin{array}{c}\text { (1,644-3,968 } \\
\text { Int. \$) }\end{array}$ & $\begin{array}{c}\text { (3,969-1,577,761 } \\
\text { Int. \$) }\end{array}$ \\
\hline $\begin{array}{l}\text { Start-up capital } \\
\text { Own savings }\end{array}$ & 61.52 & 51.58 & 52.08 & 53.50 \\
Formal loan & 7.68 & 6.58 & 10.75 & 11.80 \\
Family loan & 5.65 & 12.67 & 10.30 & 9.88 \\
Loan from money lender & 4.89 & 4.67 & 2.01 & 2.46 \\
Trade loan & 2.41 & 3.17 & 1.75 & 2.88 \\
& & & & \\
Inventory (only 2012) & & & & \\
Own savings & 63.34 & 71.82 & 74.50 & 75.33 \\
Formal loan & 1.96 & 1.34 & 1.21 & 0.98 \\
Loan from family or friends & 0.66 & 1.00 & 1.21 & 0.33 \\
Loan from money lender & 6.77 & 0.67 & 0.40 & 1.41 \\
Trade loan & 23.64 & 18.92 & 20.36 & 20.00 \\
\hline
\end{tabular}




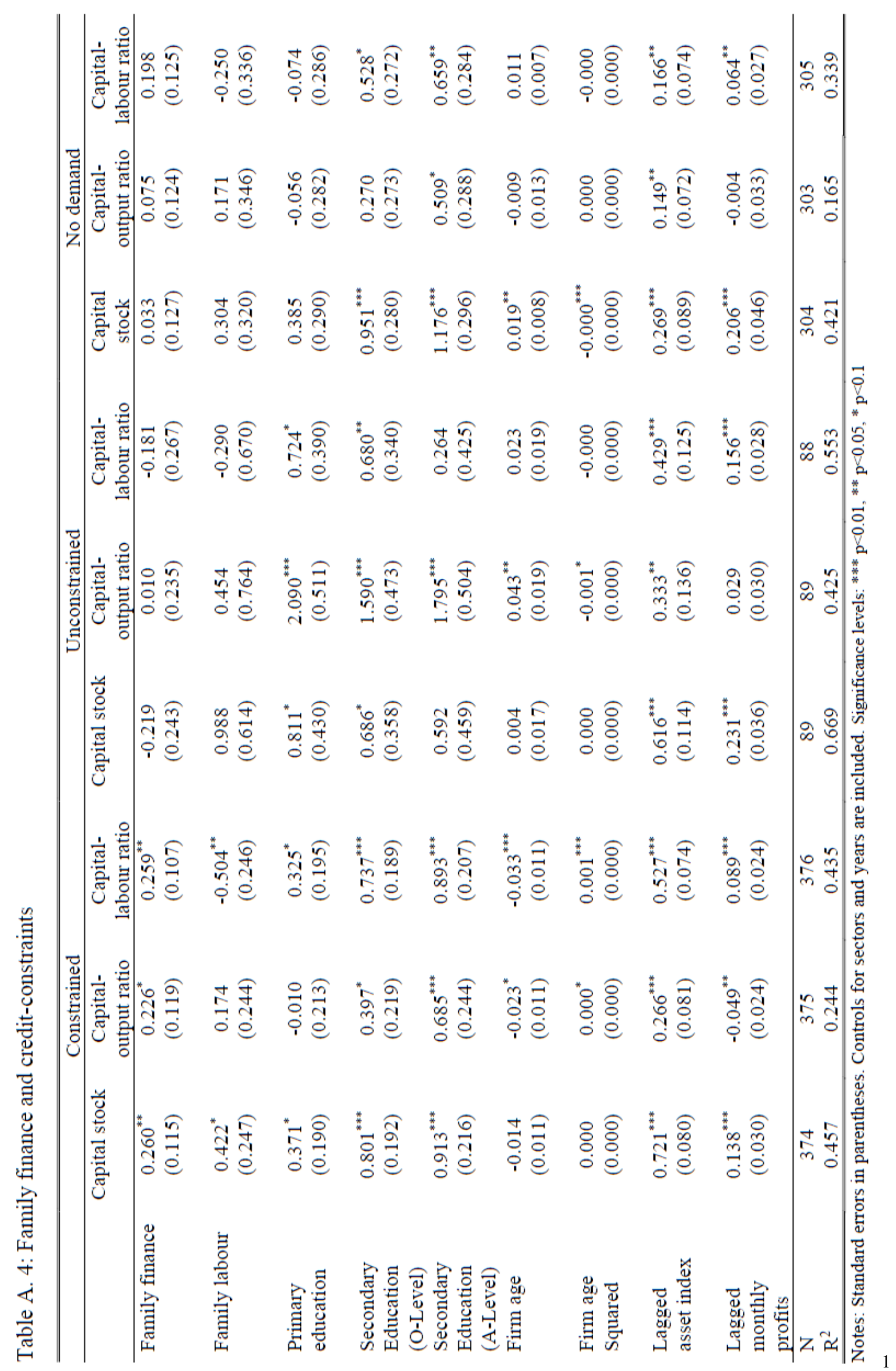




\section{APPENDIX B}

Table B. 1: EDV regression, FGLS

\begin{tabular}{|c|c|c|c|c|c|}
\hline \multirow[t]{2}{*}{ Dependent variable } & \multicolumn{5}{|c|}{ Log of hourly wage premium (Firm-time fixed effect) } \\
\hline & (I) & (II) & (III) & (IV) & $(\mathrm{V})$ \\
\hline Log of hourly profit & $\begin{array}{l}0.157 * * * \\
(0.0380)\end{array}$ & $\begin{array}{l}0.156^{* * * *} \\
(0.0359)\end{array}$ & $\begin{array}{l}0.160 * * * \\
(0.0362)\end{array}$ & $\begin{array}{l}0.159 * * * \\
(0.0358)\end{array}$ & $\begin{array}{l}0.158^{* * *} \\
(0.0373)\end{array}$ \\
\hline Log of capital-labour ratio & $\begin{array}{l}0.0460 * * \\
(0.0220)\end{array}$ & $\begin{array}{c}0.0640 * * \\
(0.0282)\end{array}$ & $\begin{array}{l}0.0607 * * \\
(0.0282)\end{array}$ & $\begin{array}{c}0.0563 * * \\
(0.0278)\end{array}$ & $\begin{array}{l}0.0566^{*} \\
(0.0301)\end{array}$ \\
\hline Firm age & & & $\begin{array}{c}0.00509 \\
(0.00526)\end{array}$ & $\begin{array}{c}0.00386 \\
(0.00512)\end{array}$ & $\begin{array}{c}0.00476 \\
(0.00501)\end{array}$ \\
\hline Firm size & & & & $\begin{array}{l}0.0848^{*} \\
(0.0507)\end{array}$ & $\begin{array}{c}0.0779 \\
(0.0522)\end{array}$ \\
\hline $\begin{array}{l}\text { Education employer: } \\
\text { No education }\end{array}$ & & & & & $\begin{array}{l}-0.167 \\
(0.200)\end{array}$ \\
\hline $\begin{array}{l}\text { Education employer: } \\
\text { Completed primary } \\
\text { education }\end{array}$ & & & & & $\begin{array}{c}0.158 \\
(0.170)\end{array}$ \\
\hline $\begin{array}{l}\text { Education employer: } \\
\text { Completed secondary } \\
\text { education }\end{array}$ & & & & & $\begin{array}{c}0.00861 \\
(0.175)\end{array}$ \\
\hline $\begin{array}{l}\text { Manufacturing of printing/ } \\
\text { paper products }\end{array}$ & & $\begin{array}{c}0.137 \\
(0.220)\end{array}$ & $\begin{array}{c}0.144 \\
(0.219)\end{array}$ & $\begin{array}{c}0.149 \\
(0.220)\end{array}$ & $\begin{array}{c}0.157 \\
(0.203)\end{array}$ \\
\hline $\begin{array}{l}\text { Manufacturing of textile/ } \\
\text { wearing apparel }\end{array}$ & & $\begin{array}{c}0.399 * * \\
(0.200)\end{array}$ & $\begin{array}{c}0.407 * * \\
(0.200)\end{array}$ & $\begin{array}{c}0.383^{* *} \\
(0.191)\end{array}$ & $\begin{array}{l}0.397 * \\
(0.207)\end{array}$ \\
\hline $\begin{array}{l}\text { Manufacturing } \\
\text { (remaining sectors) }\end{array}$ & & $\begin{array}{c}0.197 \\
(0.124)\end{array}$ & $\begin{array}{c}0.157 \\
(0.130)\end{array}$ & $\begin{array}{c}0.134 \\
(0.131)\end{array}$ & $\begin{array}{l}0.0916 \\
(0.139)\end{array}$ \\
\hline $\begin{array}{l}\text { Retail clothing, footwear } \\
\text { and leather }\end{array}$ & & $\begin{array}{l}-0.0986 \\
(0.272)\end{array}$ & $\begin{array}{l}-0.0705 \\
(0.279)\end{array}$ & $\begin{array}{l}-0.0604 \\
(0.279)\end{array}$ & $\begin{array}{l}-0.0445 \\
(0.283)\end{array}$ \\
\hline $\begin{array}{l}\text { Retail electric, phones, } \\
\text { household appliances }\end{array}$ & & $\begin{array}{c}0.318 \\
(0.213)\end{array}$ & $\begin{array}{c}0.294 \\
(0.210)\end{array}$ & $\begin{array}{c}0.294 \\
(0.206)\end{array}$ & $\begin{array}{l}0.265 \\
(0.219)\end{array}$ \\
\hline $\begin{array}{l}\text { Retail and wholesale } \\
\text { (remaining sectors) }\end{array}$ & & $\begin{array}{c}0.187 \\
(0.204)\end{array}$ & $\begin{array}{c}0.200 \\
(0.207)\end{array}$ & $\begin{array}{c}0.182 \\
(0.222)\end{array}$ & $\begin{array}{c}0.178 \\
(0.232)\end{array}$ \\
\hline Other & & $\begin{array}{c}-0.369 * * \\
(0.182)\end{array}$ & $\begin{array}{c}-0.377 * * \\
(0.181)\end{array}$ & $\begin{array}{c}-0.369 * * \\
(0.180)\end{array}$ & $\begin{array}{c}-0.374 * * \\
(0.184)\end{array}$ \\
\hline Constant & $\begin{array}{c}-0.479 * * * \\
(0.0456)\end{array}$ & $\begin{array}{c}-0.625 * * * \\
(0.141)\end{array}$ & $\begin{array}{c}-0.661 * * * \\
(0.143)\end{array}$ & $\begin{array}{c}-0.950 * * * \\
(0.252)\end{array}$ & $\begin{array}{c}-0.966 * * * \\
(0.316)\end{array}$ \\
\hline Observations & 332 & 332 & 331 & 331 & 329 \\
\hline Adjusted R-squared & 0.0811 & 0.149 & 0.149 & 0.155 & 0.161 \\
\hline
\end{tabular}

Notes: "No education" is the baseline category for the entrepreneur education variables. The baseline category for the industry controls is industry 1 ("Hair dressing and beauty"). The baseline category for the year controls is the year 2013. Robust standard errors in parentheses. Significance levels: *** $\mathrm{p}<0.01, * * \mathrm{p}<0.05,{ }^{*} \mathrm{p}<0.1$ 
Table B. 2: Wage regression with 2012 data only

\begin{tabular}{lc}
\hline \hline Dependent variable & Log of hourly wage \\
\hline No education & OLS \\
& -0.004 \\
Primary education & $(0.507)$ \\
& $-0.944^{* *}$ \\
& $(0.371)$
\end{tabular}

Secondary education $\quad-0.324$

(0.392)

Casual worker

$-0.731^{*}$

$(0.431)$

Hourly pay

$3.479 * * *$

(0.479)

Weekly pay

0.426

(0.380)

Tenure

0.061

(0.127)

Tenure squared

0.004

(0.010)

Female

$-0.883^{* * *} *$

(0.308)

Age

0.094

(0.126)

Age squared

$-0.001$

(0.002)

Constant

$6.135^{* * *}$

(1.857)

\begin{tabular}{lc}
\hline Observations & 164 \\
Adjusted R-squared & 0.361 \\
\hline Notes: The baseline category of the worker status variables (casual worker, apprentice) is "regular workers". "Tertiary \\
education" is the baseline category for the worker education variables. "Monthly pay" is the reference category for the \\
dummies that signal the periodicity of pay. The categories "apprentice" and "daily pay" are omitted because of collinearity. \\
All standard errors (in parenthesis) are clustered at the firm level. Significance levels: *** $\mathrm{p}<0.01, * * \mathrm{p}<0.05$, , $\mathrm{p}<0.1$
\end{tabular}




\section{GEORG-AUGUST-UNIVERSITÄT GÖTTINGEN \\ Ph.D. Programme in Economics}

\section{Declaration for admission to the doctoral examination}

\section{I confirm}

1. that the dissertation that I submitted

\section{Employment and Micro and Small Enterprises}

was produced independently without assistance from external parties, and not contrary to high scientific standards and integrity,

2. that I have adhered to the examination regulations, including upholding a high degree of scientific integrity, which includes the strict and proper use of citations so that the inclusion of other ideas in the dissertation are clearly distinguished,

3. that in the process of completing this doctoral thesis, no intermediaries were compensated to assist me neither with the admissions or preparation processes, and in this process,

- no remuneration or equivalent compensation were provided,

- no services were engaged that may contradict the purpose of producing a doctoral thesis,

4. that I have not submitted this dissertation or parts of this dissertation elsewhere.

I am aware that false claims (and the discovery of those false claims now, and in the future) with regards to the declaration for admission to the doctoral examination can lead to the invalidation or revoking of the doctoral degree.

Date, Signature 


\section{GEORG-AUGUST-UNIVERSITÄT GÖTTINGEN}

Ph.D. Programme in Economics

\section{Declaration about co-authored papers}

This dissertation features four stand-alone research articles presented in Chapters 2 to 5 .

While all four contributions can be read and understood independently, they are connected to each other thematically and build successively upon each other.

Chapter 2 is joint work with Martin Ostermeier, Jann Lay and Sebastian Prediger. It was conceptualised jointly by all authors. Martin Ostermeier and I did the empirical illustration. Martin Ostermeier and I wrote the draft, based on earlier work of Jann Lay and Sebastian Prediger.

I am the single author of Chapter 3.

Chapter 4 has been written in co-authorship with Anna Giolbas. We jointly conceptualized the chapter. We both contribute to the review of the literature. I wrote the analytical framework. We both performed the empirical analysis, interpreted and discussed the results.

Chapter 5 is joint work with Natascha Haitz. It is based on previous research of Natascha Haitz. I conceptualized the chapter further, extended the empirical analysis and wrote the draft.

I confirm that that there are no other persons who satisfy the criteria for authorship but are not listed.

Date, Signature 